\title{
Overweight Truck Shipments to Nuclear Waste Repositories: Legal, Political, Administrative, and Operational Considerations
}

\author{
Technical Report
}

$\frac{\text { March } 1986}{\text { DISCLAIMER }}$

\begin{abstract}
This report was prepared as an account of work sponsored by an agency of the United States Government. Neither the United States Government nor any agency thereof, nor any of their employees, makes any warranty, express or implied, or assumes any legal liability or responsibility for the accuracy, completeness, or usefulness of any information, apparatus, product, or process disclosed, or represents that its use would not infringe privately owned rights. Reference herein to any specific commercial product, process, or service by trade name, trademark, manufacturer, or otherwise does not necessarily constitute or imply its endorsement, recommendation, or favoring by the United States Government or any agency thereof. The views and opinions of authors expressed herein do not necessarily state or reflect those of the United States Government or any agency thereof.
\end{abstract}

This document is

Office of Transportation Systems and Planning

Battelle Memorial Institute

505 King Avenue

Columbus, Ohio 43201-2693

\section{PUBLICLY RELEASABLE}

haves Qhathame

Authorizing Official

Date: $11 / 22 / 2005$

The content of this report was effective as of October 1985. This report was prepared by Office of Transportation Systems and Planning, Battelle Project Management Division, Columbus, OH, under Contract No. DE-AC02-83CH10139 with the U.S. Department of Energy. 


\section{DISCLAIMER}

This report was prepared as an account of work sponsored by an agency of the United States Government. Neither the United States Government nor any agency Thereof, nor any of their employees, makes any warranty, express or implied, or assumes any legal liability or responsibility for the accuracy, completeness, or usefulness of any information, apparatus, product, or process disclosed, or represents that its use would not infringe privately owned rights. Reference herein to any specific commercial product, process, or service by trade name, trademark, manufacturer, or otherwise does not necessarily constitute or imply its endorsement, recommendation, or favoring by the United States Government or any agency thereof. The views and opinions of authors expressed herein do not necessarily state or reflect those of the United States Government or any agency thereof. 


\section{DISCLAIMER}

Portions of this document may be illegible in electronic image products. Images are produced from the best available original document. 


\section{ACKNOWLEDGMENTS}

This report was prepared by Battelle Project Management Division, Office of Transportation Systems and Planning at the request of the Department of Energy's Office of Civilian Radioactive Waste Management and the Chicago Operations office. John Allen served as project leader and was assisted by Shashikant Gupta and Douglas Ladd. This study could not have been completed without important information provided by Chuck Mayer, Earl Rutenkroger, and Mike Garcia of Tri-State Motor Transit Company; John Mangusi and Kurt Goldman of Transnuclear, Inc.; Harold Brown, David 0liver, and Roger Mingo of the U.S. Department of Transportation; and John Hewitt of the American Association of State Highway and Transportation Officials. Finally, DOE's Transportation Operations and Traffic Management staff and contractor traffic management personnel provided valuable information by participating in a survey questionnaire. 


\section{ABSTRACT}

This report, prepared for the Chicago Operations Office and the Office of Civilian Radioactive Waste Management (OCRWM) of the U.S. Department of Energy (DOE), identifies and analyzes legal, political, administrative, and operational issues that could affect an OCRWM decision to develop an overweight truck cask fleet for the commercial nuclear waste repository program. It also provides information required by $D O E$ on vehicle size-and-weight administration and regulation, pertinent to nuclear waste shipments.

Current legal-weight truck casks have a payload of one pressurizedwater reactor spent fuel element or two boiling-water reactor spent fuel elements (1 PWR/2 BWR). For the requirements of the 1960 s and 1970s, casks were designed with massive shielding to accommodate 6-month-old spent fuel; the gross vehicle weight was limited to 73,280 pounds. Spent fuel to be moved in the 1990s will have aged five years or more. Gross vehicle weight limitation for the Interstate highway system has been increased to 80,000 pounds. These changes allow the design of 25-ton legal-weight truck casks with payloads of 2 PWR/5 BWR.

These changes may also allow the development of a 40-ton overweight truck cask with a payload of 4 PWR/10 BWR. Such overweight casks will result in significantly fewer highway shipments compared with legal-weight casks, with potential reductions in transport-related repository risks and costs. These advantages must be weighed against a number of institutional issues surrounding such overweight shipments before a substantial commitment is made to develop an overweight truck cask fleet. This report discusses these issues in detail and provides recommended actions to DOE. 
The National Waste Terminal Storage (NWTS) program was established in 1976 by the U.S. Department of Energy's (DOE) predecessor, the Energy Research and Development Administration. In September 1983, this program became the Civilian Radioactive Waste Management (CRWM) Program. Its purpose is to develop technology and provide facilities for safe, environmentally acceptable, permanent disposal of high-level waste (HLW). HLW includes wastes from both commercial and defense sources, such as spent (used) fuel from nuclear power reactors, accumulations of wastes from production of nuclear weapons, and solidified wastes from fuel reprocessing.

The information in this report pertains to the transportation studies of the Transportation Program Office established at DOE's Chicago Operations Office to support the Office of Civilian Radioactive Waste Management. 


\section{EXECUTIVE SUMMARY}

The use of overweight truck casks offers the promise of substantially reducing the number of truck shipments required for the nuclear waste repository program, with potential reductions in transportation cost and risk. However, overweight truck shipments entail a number of institutional issues that should be carefully considered by the U.S. Department of Energy (DOE) before it makes a decision to base its truck fleet on legal-weight or overweight casks.

Issues which could affect the use of overweight truck shipments to nuclear waste repositories are grouped in this report into three categories. The first set of issues involves a number of Federal and State concerns that make up the political environment in which DOE must seek support for the development of an overweight truck cask fleet. First among these concerns is the relationship between the deterioration of the nation's highways and bridges and damage caused by heavy trucks. In addition, the Federal government lays increasing emphasis on strengthening State weight-enforcement programs and reducing overweight permits. Inadequate heavy truck user taxes and heavy truck safety issues are also Federal concerns. Heavy trucks have been the subject of considerable debate and numerous studies at both the Federal and State levels for the past several years. These factors will affect the manner in which States will receive the idea of routine overweight nuclear waste shipments.

With regard to highway damage and the nuclear waste repository program however, it appears that overweight shipments may cause less total highway damage than legal-weight shipments over the life of the repository program. An analysis has been conducted that compares the relative highway damage of various cask weights and payloads, and various vehicle axle configurations, using mathematical relationships established by the American Association of State Highway and Transportation Officials (AASHTO). Results indicate that a single vehicle loaded with a 4 PWR/10 BWR overweight cask with a gross vehicle weight of 116,000 pounds would cause about 70 percent more highway damage than a vehicle loaded with a 2 PWR/5 BWR legal-weight cask at a 
gross vehicle weight of 80,000 pounds. However, when the total number of repository shipments are taken into account, overweight shipments would result in about 15 percent less total highway damage than the required number of legal-weight shipments. In addition, it should be kept in perspective that repository-related overweight shipments would only be a small fraction of all future heavy truck shipments in the United States over the 30-year lifetime of the repository program.

The second set of issues involves State permitting, which presents more difficulty than the general political environment discussed above. Administrative difficulties involving state permitting, such as nonuniform procedures, could become burdensome but may be surmountable with program planning and shipping experience. More troublesome is the fact that State vehicle weight-permit policies can change over time. Also, some local governments and turnpike/bridge authorities have autonomous overweight-permit authority. The most uncertain State permitting issue is load divisibility. Many States will not issue overweight permits if the load is divisible (i.e., the load can be further divided or reduced so that it can be shipped legal-weight). It must be established whether a multi-element spent fuel cask is a divisible load, and if so, whether certain States can legally issue a divisible-load permit to allow operation on the Federal-aid system. The answer to these questions involves legal and technical issues which are discussed in detail in the report. It is recommended that the U.S. Department of Energy (DOE) encourage the standardized interpretation that a multi-element cask is a nondivisible load to avoid the legal uncertainties involved with the latter part of the question.

Much of the potential opposition to State permitting may be diminished if the final overweight cask and vehicle designs are reasonable to State weight authorities. Based upon the analysis in this report, if overweight cask/vehicle systems can be developed such that single, tandem, and tridem axle weights do not exceed limits allowed by States under permit, and the gross vehicle weight can be kept below 110,000 pounds, widespread State permit acceptance may be possible. The one potential barrier to permitting could be physical limitations of crucial off-system roads and bridges, which are 
typically designed to a lower standard than that for Federal-aid facilities. These need to be independently evaluated by DOE.

The third set of issues involves DOE policy and repository program considerations. Congressional oversight committees have strongly criticized Federal agencies' use of overweight shipments. Partly in response to this, DOE established a policy in 1978 that discourages the use of overweight shipments of any commodity unless the load is nondivisible, and no other mode of transport is available. DOE traffic managers typically do not allow contractors to use overweight shipments and, according to a recently conducted survey, are generally not in favor of overweight casks because of increased costs, administrative burden, and the loss of control of a shipment associated with State permitting. Another program consideration will be the impact of State permit time restrictions on repository shipping schedules. Most States do not allow travel under permit at night or on weekends and holidays, and most northern States have frost laws which restrict overweight movement during spring and fall.

It would appear that the use of overweight shipments may reduce repository transport-related cost and risk, although this is an area that needs to be more carefully examined by DOE. An analysis has been conducted that compares occupational exposure times and transport costs associated with legal-weight and overweight cask options for a specified shipment scenario. Results indicate that total exposure time to drivers and facility personnel is substantially reduced by using overweight casks because of the need to handle fewer shipments. Also, the 40-ton overweight cask was found to have lower total costs than the 25-ton legal-weight cask. However, the cost advantage of overweight casks over legal-weight casks was not as great as some would expect. The primary reasons are that transit times for overweight moves are increased because (1) there are permit time restrictions, (2) facility turnaround times are longer, and (3) tariff charges are higher for overweight shipments. The cost analysis is based upon some assumptions, which are currently being evaluated by DOE, particularly cask lease rates and facility loading/unloading times. It is conceivable that the results could change with more recent data. As indicated above, this is an area that OCRWM should 
analyze more rigorously if cost is to be considered the key reason for pursuing the overweight cask option.

Finally, the last issue relating to program considerations is the loss of control by DOE over the nuclear waste shipments. States would have the additional shipment control that comes with overweight permitting. Most State overweight permits specify routes, speeds, times, duration, fee, and minimum financial responsibility, and some may require escorts and more frequent inspections. Vehicle weight regulation and enforcement is almost entirely a State and local function with little direct Federal involvement. In short, once a shipment is covered by a State overweight permit, it is subject to almost total control of State weight authorities. It is possible that the umbrella of Federal preemption associated with hazardous material transportation would be seriously diminished once vehicle weight becomes an issue.

\section{CONCLUSION AND RECOMMENDATIONS}

A number of problems are related to the use of overweight trucks for shipments to commercial nuclear waste repositories. Some of these problems can be mitigated to a certain degree as discussed in Chapter 5 of this report. Other issues are more serious and should be carefully considered by DOE before a substantial commitment is made to develop overweight truck casks. Nevertheless, there appear to be some valid reasons to continue early consideration of overweight trucks as a potential modal option for the repository program, if for no other reason than to have the flexibility to move spent fuel from reactors without rail access to the closest railhead for intermodal shipments.

The following recommendations involve possible activities to address key issues discussed in this report. The feasibility and acceptance of overweight truck shipments to nuclear waste repositories should be continually re-examined over the next several years as new information becomes available from these activities.

Recommendations include the following:

1. Establish a management-level working group on overweight nuclear shipments composed of DOE, AASHTO, the Federal Highway Administration, and carrier representatives to address the following key problems that will probably require formal resolution: 
- Interpretation of the divisibility of a multi-element spent fue 1 cask

- Legal interpretation of the ability of States to issue divisible load permits for operation on the Federal-aid system

- The need to obtain near unanimity among States on maximum allowable permit weights and vehicle configurations

- The need for virtual certainty among all States that repetitive overweight truck permits will be available and State permitting policy will be consistent over time.

2. Proceed with early planning to develop overweight cask designs along with legal-weight truck casks, rail casks, and other cask concepts. Cask and vehicle designers should be encouraged to consider the following:

- Axle weights should not exceed single, tandem, and tridem axle permit limits prescribed by almost a 11 States

- Axle spacing should allow compliance with Federal and State bridge formulas under almost any situation

- Gross vehicle weight should ideally be kept to 110,000 pounds or less to enhance chances of universal permittability.

3. Re-examine current DOE overweight truck policy and consider lifting self-imposed restrictions for commercial nuclear waste relating to availability of other modes.

4. Conduct an audit of off-system bridge and highway limitations for each reactor and repository site.

5. Conduct detailed case analys is of an overweight shipping campaign. This would allow the documentation of the State permit approval and issuance process, scheduling considerations, time and route restrictions, occupational exposure times, turnaround times, and costs involved with overweight shipments for detailed comparison with legal-weight shipments. 


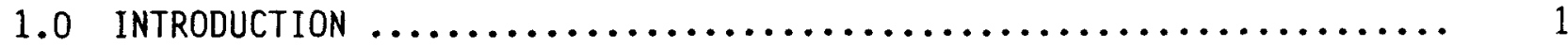

2.0 VEHICLE SIZE AND WEIGHT CONTROL $\ldots \ldots \ldots \ldots \ldots \ldots \ldots \ldots \ldots \ldots \ldots \ldots \ldots \ldots$

2.1 The Federal-Aid Highway System $\ldots \ldots \ldots \ldots \ldots \ldots \ldots \ldots \ldots \ldots, 3$

2.1 .1 Overview ................................... 3

2.1.2 Evolution of Highway Weight Limits $\ldots \ldots \ldots \ldots \ldots \ldots \ldots \ldots . .3$

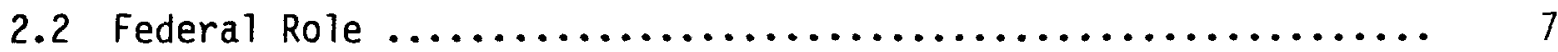

2.2.1 Statutes/Regulations $\ldots \ldots \ldots \ldots \ldots \ldots \ldots \ldots \ldots \ldots \ldots \ldots, 7$

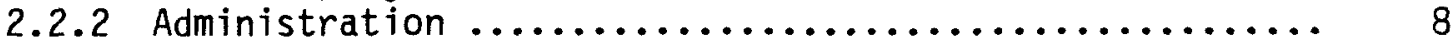

2.2.2.1 Federal Highway Administration ............ 8

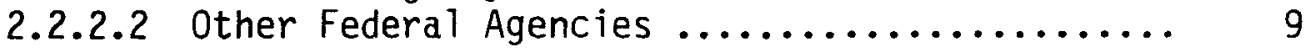

2.2.2.3 DOE Overweight Truck Policy ............... 9

2.3 State Role $\ldots \ldots \ldots \ldots \ldots \ldots \ldots \ldots \ldots \ldots \ldots \ldots \ldots \ldots \ldots \ldots \ldots \ldots$

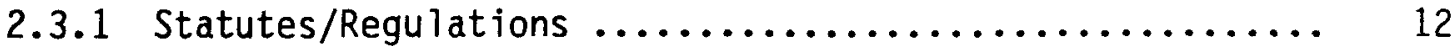

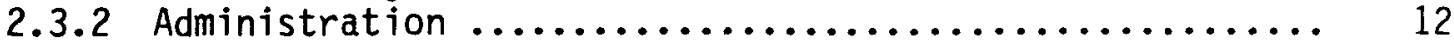

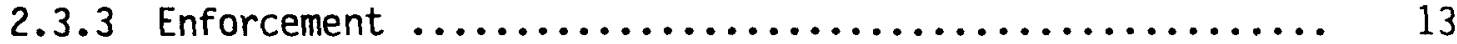

2.3.4 0ther Weight Control Authorities ................ 14

2.3.4.1 Local Governments ................... 14

2.3.4.2 Toll Facilities ..................... 14

2.4 Effect of Vehicle Weight on Highways and Bridges ......... 15

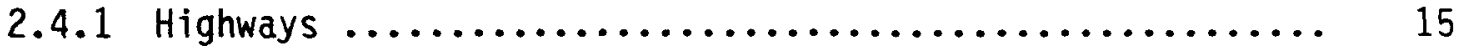

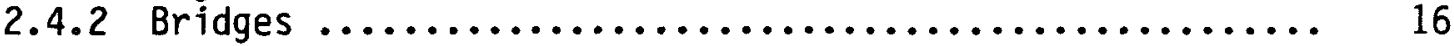

3.0 STATE WEIGHT LIMITS AND PERMIT OPERATIONS $\ldots \ldots \ldots \ldots \ldots \ldots \ldots \ldots \ldots \ldots \ldots$

3.1 State Weight Limits $\ldots \ldots \ldots \ldots \ldots \ldots \ldots \ldots \ldots \ldots \ldots \ldots \ldots \ldots \ldots$

3.1 .1 Interstate Highways $\ldots \ldots \ldots \ldots \ldots \ldots \ldots \ldots \ldots \ldots \ldots \ldots . \ldots \ldots$

3.1.1.1 Axle Weight Limits ................... 19

3.1.1.2 Gross Vehicle Weight and Bridge Gross

Weight Formula ...................... 20

3.1.2 Exceptions From Interstate Limits ............... 21 


\section{TABLE OF CONTENTS}

(Cont inued)

Page

3.1.2.1 Grandfather Provisions ................ 24

3.1.2.2 Nondivisible Load Special Permits ........... 25

3.1.3 Noninterstate Highway Limits ................. 25

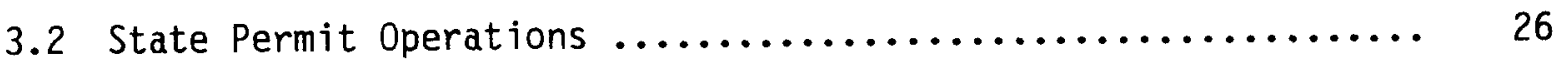

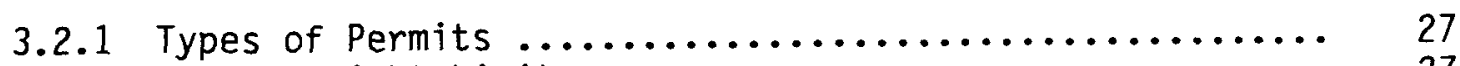

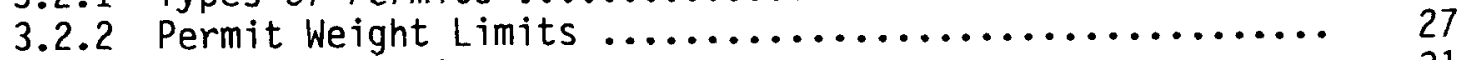

3.2.3 Time Restrictions ......................... 31

3.2.3.1 Time-of-Day and Day-of-Week ............. 31

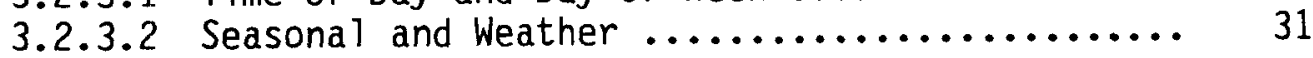

3.2 .4 Route Restrictions ........................ 32

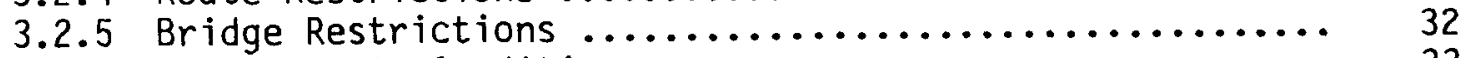

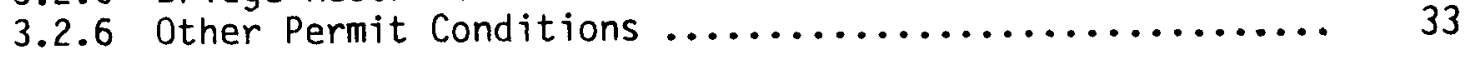

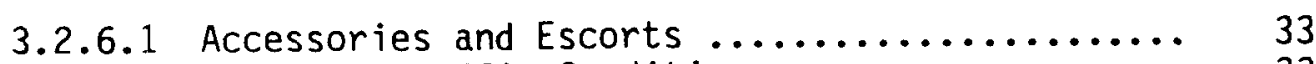

3.2.6.2 Road and Traffic Conditions .............. 33

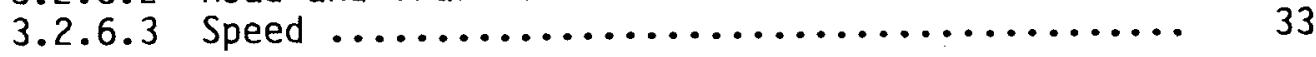

3.2 .7 Permit Applications $\ldots \ldots \ldots \ldots \ldots \ldots \ldots \ldots \ldots \ldots \ldots \ldots \ldots \ldots \ldots \ldots \ldots$

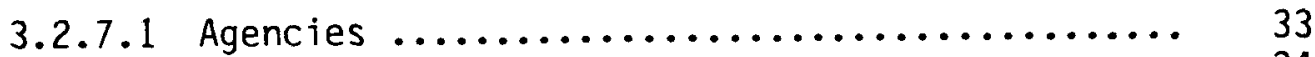

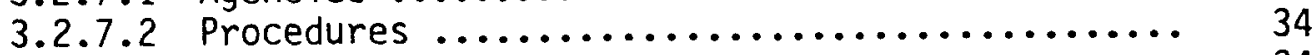

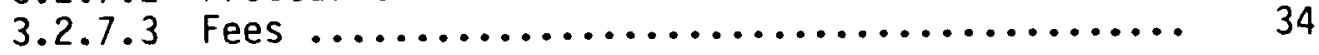

3.2.8 Financial Responsibility .................. 35

3.3 State Weight Table $\ldots \ldots \ldots \ldots \ldots \ldots \ldots \ldots \ldots \ldots \ldots \ldots \ldots \ldots \ldots \ldots$

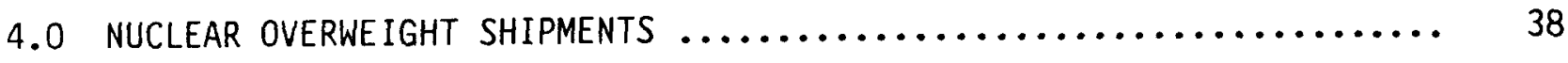

4.1 Past Considerations for Developing an Overweight

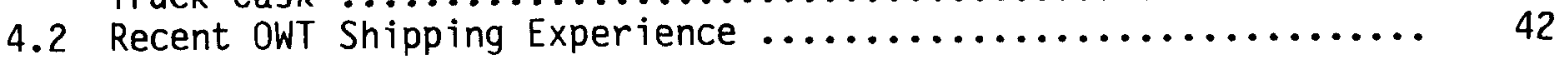

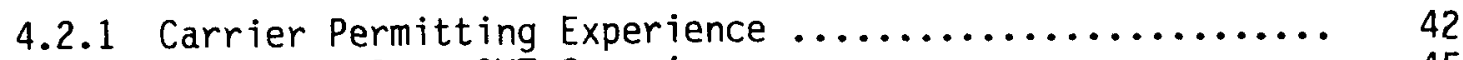

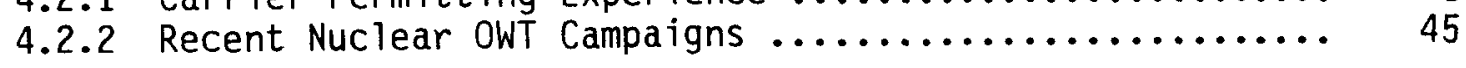

4.2.2.1 West Valley, NY, to Dresden, IL .......... 45

4.2.2.2 West Valley, NY, to Oyster Creek, NJ ........ 46 


\section{TABLE OF CONTENTS \\ (Cont inued)}

Page

4.2.2.3 Canoga Park, CA, to Savannah River, SC ...... 48

4.2.2.4 Peach Bottom, PA, to Idaho Falls, ID ....... 49

4.3 Representative Cask/Vehicle Designs ................... 49

4.3.1 State Permitting for Representative OWT Design ........ 50

4.3 .2 Comparison of Impacts $\ldots \ldots \ldots \ldots \ldots \ldots \ldots \ldots \ldots \ldots \ldots \ldots . \ldots \ldots \ldots$

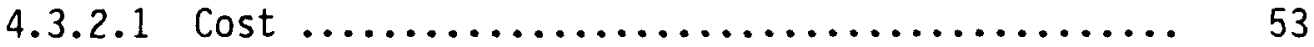

4.3.2.2 Occupational Exposure Time $\ldots \ldots \ldots \ldots \ldots \ldots \ldots . . . \ldots 5$

4.3.2.3 Highway Damage ...................... 56

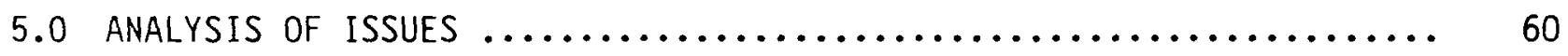

5.1 Federal and State Concern Over Heavy Trucks ............. 60

5.1.1 Growing Concern Over Highway and Bridge

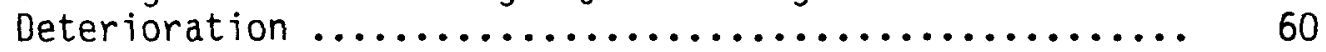

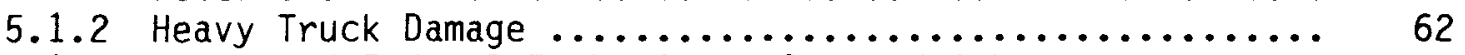

5.1.3 Increased Federal Emphas is on State Weight

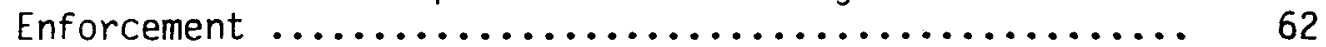

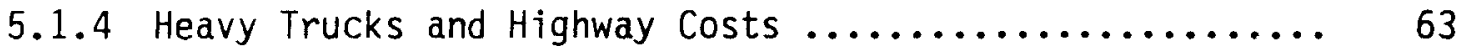

5.1 .5 Concern Over Heavy Truck Safety .................... 64

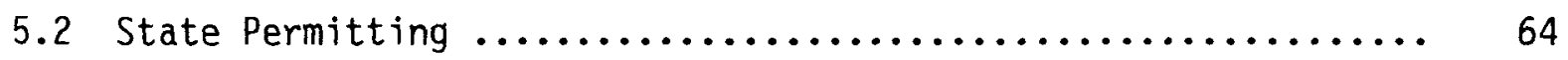

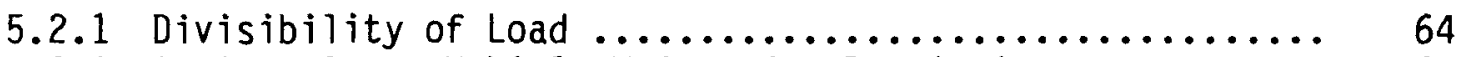

5.2.2 Optimum Gross Vehicle Weight for Permitting .......... 67

5.2.3 Changes in State Permit Policies Over Time ........... 68

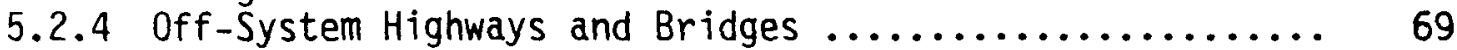

5.2 .5 Administrative Constraints ................... 70

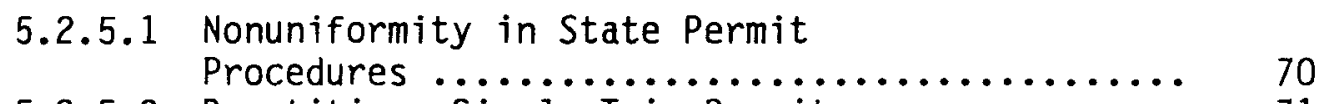

5.2.5.2 Repetitive, Single-Trip Permits ........... 71

5.3 Program Considerations $\ldots \ldots \ldots \ldots \ldots \ldots \ldots \ldots \ldots \ldots \ldots \ldots \ldots \ldots \ldots$

5.3.1 Current DOE Overweight Truck Policy ............... 71

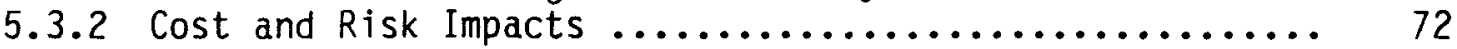

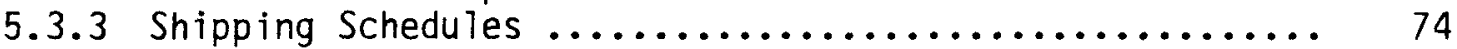

5.3 .4 Loss of Control $\ldots \ldots \ldots \ldots \ldots \ldots \ldots \ldots \ldots \ldots \ldots \ldots \ldots \ldots \ldots . \ldots \ldots \ldots$ 
TABLE OF CONTENTS

(Cont inued)

$\underline{\text { Page }}$

6.0 CONCLUSION AND RECOMMENDATIONS $\ldots \ldots \ldots \ldots \ldots \ldots \ldots \ldots \ldots \ldots \ldots \ldots \ldots$

7.0 REFERENCES $\ldots \ldots \ldots \ldots \ldots \ldots \ldots \ldots \ldots \ldots \ldots \ldots \ldots \ldots \ldots \ldots \ldots \ldots \ldots \ldots \ldots$

APPENDIX A

STATE PERMIT REQUIREMENTS FOR OVERWEIGHT VEHICLES AND PERMIT

REQUIREMENTS FOR TOLL ROADS $\ldots \ldots \ldots \ldots \ldots \ldots \ldots \ldots \ldots \ldots \ldots \ldots \ldots \ldots \ldots \ldots \ldots \ldots$

APPENDIX B

APPLICATION OF BRIDGE GROSS WEIGHT FORMULA $\ldots \ldots \ldots \ldots \ldots \ldots \ldots \ldots \ldots \ldots \ldots$

APPENDIX C

REPRESENTATIVE CASK/VEHICLE CONFIGURATIONS $\ldots \ldots \ldots \ldots \ldots \ldots \ldots \ldots \ldots \ldots \ldots$

APPENDIX D

CALCULATION OF EQUIVALENT STANDARD AXLE LOADS (ESALS) $\ldots \ldots \ldots \ldots \ldots \ldots \ldots$

APPENDIX E

SUMMARY OF DOE TRAFFIC MANAGER RESPONSES TO QUESTIONNAIRE

ON OVERWEIGHT NUCLEAR SHIPMENTS 


\section{LIST OF TABLES}

$\underline{\text { Page }}$

Table 1. Heavy Trucks and Bridge Design Standards .............. 17

Table 2. Uniform Vehicle Weight Limits Adopted by States Pursuant to the Surface Transportation Assistance Act of $1982 \ldots \ldots \ldots . \quad 18$

Table 3. Bridge Gross Weight Formula B $\ldots \ldots \ldots \ldots \ldots \ldots \ldots \ldots \ldots$

Table 4. Allowable Gross Vehicle Weights Under the Federal

Bridge Formula ............................... 22

Table 5. State Weight Limits Which Exceed Federal Limits by

Exceptions from the Surface Transportation Assistance

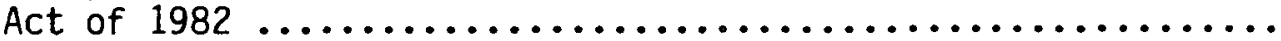

Table 6. Deviation of Noninterstate Gross Vehicle Weight Limits

From Federal Limit ............................. 26

Table 7. State Overweight Permits Issued in Fiscal Year $1983 \ldots \ldots \ldots . .28$

Table 8. State Policies for Shipments Exceeding Permit Maximum

Limits ....................................... 30

Table 9. Number of States With Time Restrictions in Overweight

Permits ..................................... 31

Table 10. Methods of Permit Application and Issuance $\ldots \ldots \ldots \ldots \ldots \ldots \ldots$

Table 11. State Weight Table $\ldots \ldots \ldots \ldots \ldots \ldots \ldots \ldots \ldots \ldots \ldots \ldots \ldots \ldots \ldots$

Table 12. Overweight Permits Required for West Valley-Dresden

Campaign

Table 13. Cask/Vehicle Configurations for Comparison .............. 52

Table 14. Comparison of Impacts $\ldots \ldots \ldots \ldots \ldots \ldots \ldots \ldots \ldots \ldots \ldots \ldots \ldots$

\section{LIST OF FIGURES}

Figure 1. Practical Maximum GVW Permit Limits Allowed by States for Various Axle Configurations 


\subsection{INTRODUCTION}

The Office of Civilian Radioactive Waste Management (OCRWM) of the U.S. Department of Energy (DOE) is responsible for the development of a transportation system to support the nuclear waste repository program which is to begin operation in the late 1990's. A crucial question to be answered early in the planning process involves the type of packaging to be developed. This is partly dependent upon the preferred mode of transport. A number of modal alternatives are available to OCRWM, including highway, rail, and barge, or intermodal arrangements employing any combination of these. The relative importance of these modes will be influenced greatly by Congressional action on a proposal to be submitted by DOE to develop an integrated waste management system involving a Monitored Retrievable Storage (MRS) facility. DOE will take this into consideration when making its final decisions on preferred modes and the mix of cask types to be developed.

Regardless of the MRS decision, it is certain that highway shipments will play an important role. About 30 percent of nuclear reactors expected to be in operation by the year 2000 will not have rail access. Except for those few sites located on navigable water, the only alternative will be the highway mode.

Casks used for highway shipment of spent nuclear fuel are characterized by an extremely low payload-to-weight ratio. Currently available legalweight truck casks include the National Lead, Inc. (NLI) $1 / 2$, which has a payload of only one pressurized-water reactor spent fuel element or two boiling-water reactor spent fuel elements ( 1 PWR/2 BWR) and, when fully loaded and placed upon a transport vehicle, is close to legal gross vehicle weight limits. Future casks will require less shielding because much of the spent fuel to be moved will have aged considerably. However, present indications are that the maximum capacity of future legal-weight truck casks will still be only 2 PWR/5 BWR spent fue 1 elements.

Thus, overweight truck casks offer the only alternative for substantially increasing highway shipment productivity. The currently available overweight casks include Transnuclear, Inc.'s TN-8 and TN-9, which have payloads of 3 PWR and 7 BWR assemblies, respectively. Overweight truck (OWT) 
casks with a payload of 4 PWR/10 BWR assemblies are conceivable for the older fuel to be shipped in the future. This promises substantial reductions in the number of required highway shipments for the repository program. However, there are a number of issues associated with the operation of overweight vehicles that need to be carefully considered by DOE before it proceeds with the development of an overweight truck cask fleet.

There is great concern today at both the Federal and State levels with the deterioration of the nation's highways and bridges, and the relationship of this deterioration to heavy trucks. In the late 1970's, the House Ways and Means Subcommittee on Oversight held a series of hearings which focused attention on these problems (U.S. Congress, 1978). In 1979, the General Accounting office (GAO) published a comprehensive report which was highly critical of heavy trucks, State weight enforcement, and Federal oversight (GAO, 1979). Congress initiated a series of studies in the late 1970's and early 1980's to investigate highway cost allocation, truck size and weight alternatives, the condition of bridges, and other topics related to heavy trucks. These concerns have continued up to the present. They have a great impact on State legal-weight and overweight permit policies, as will be discussed.

The primary purpose of this report is to identify and analyze the legal, political, administrative, and operational issues that could impact a DOE decision to develop an overweight truck cask fleet. A secondary purpose is to provide sufficient background and detailed information in the report, so that it can serve as a useful resource document for DOE staff on the topic of highway weight control and State permit limits and operations. The next three chapters provide much of the background information necessary to identify and understand issues involving heavy trucks. Chapter 2 provides an overview and the historical development of the Federal-aid highway system and size and weight limits, as well as a discussion of the various roles played by Federal and State governments. Chapter 3 documents State weight limits and State permit operations. Chapter 4 presents a review of recent experience with overweight nuclear shipments and includes a comparison of impacts between legal-weight and overweight casks. Finally, Chapter 5 organizes and analyzes the key issues based upon the groundwork laid by previous chapters. Chapter 6 presents conclusions and recommendations based upon the analys is of key issues. 


\subsection{VEHICLE SIZE AND WEIGHT CONTROL}

\subsection{THE FEDERAL-AID HIGHWAY SYSTEM}

\section{1 .1 Overview}

The present Federal-aid highway system consists of 810,000 miles of roadway, approximately 17 percent of the total 4.7 million miles of roadway in the United States. Included within the Federal-aid system are 42,000 miles of Interstate highways, and 256,000 miles of noninterstate "primary" highways that are designated by U.S. route numbers. In addition, another 400,000 miles of highway are part of the "secondary" system which consists of feeder routes to the primary and Interstate systems. Finally, another 113,000 miles are urban, noninterstate roadways that are partially financed by Federal funds.

Generally, States with roadways that are designated part of the Federal-aid system are eligible for matching Federal funds to construct and maintain the roads. Interstate highways are eligible for up to 90 percent Federal funding and noninterstate highways up to 75 percent Federal funding. However, the roadways remain under primary control of the State in which they are located. Since 1956, the Federal government has invested over $\$ 100$ bi1lion in the Federal-aid highway system.

The evolution of weight limits on the Federai-aid highway system is

reviewed in the next section. It is presented to emphasize the important historical relationship between the financing of the system and the attempts to protect the huge Federal investment through weight limitations. It also illustrates the continuing controversy over highway cost allocation and the user fee structure as it pertains to heavy vehicles.

\subsubsection{Evolution of Highway Weight Limits}

The Federal role in highways began with the Federal-Aid Road Act of 1916. This law established some basic principles that still govern the financing of the national highway system: joint Federal/State responsibility for construction and maintenance; a matching ratio by a State to qualify for 
Federal highway funds; and apportionment formulas to determine availability of Federal funds based on the needs of different States. The system was financed from 1916 to 1956 out of the General Fund. There were highway-related taxes imposed during this time on new vehicles, gasoline, and diesel fuel but monies were not dedicated to the highway program. Concern first developed during this time period over highway damage and the need to limit the size and weight of vehicles. By 1931, all States had adopted some limitations.

In 1956 Congress passed the Federal-Aid Highway Act and established the Highway Trust Fund as a dedicated financing mechanism to build an expanded interstate highway network. This law emphasized a close correlation between users of the system and the financing of the system. Excise taxes on vehicle sales, gasoline, and diesel fuel were increased and new taxes were added, including the first heavy-vehicle use tax $(\$ 1.50$ per 1,000 pounds over 26,000 pounds gross vehicle weight). To establish a more equitable basis for financing, Congress commissioned the first highway cost allocation study to determine the appropriate level of user fees (i.e., taxes) for various classes of highway users.

Congress also established the first Federal size and weight limitations on the Interstate highway system. There was early concern that the tremendous highway investment to be made would be devalued by vehicles exceeding design limitations. Since the Federal share of the Interstate network would be about 90 percent, it was believed that federally prescribed limits were necessary, even though every State already had highway limits. Thus, the Federal-Aid Highway Act also conditioned Federal highway grants upon State enactment of the Federal maximum weight limits.

The weight limits established in 1956 were based upon recommended limits published by the American Association of State Highway and Transportation Officials (AASHTO)*. The gross weight limit of 73,280 pounds was calculated by applying the AASHTO weight tables to the largest vehicle length and wheelbase operating on the roads in 1956. Single-axle and tandem-axle weight 1 imits were set at 18,000 and 32,000 pounds, respectively. The Federal 1imits

*Formerly known as The American Association of State Highway Officials or AASHO. 
were permissive, i.e., States could adopt lower limits but not higher. The one important exception to this was the "grandfather clause," which allowed higher State limits only if States already permitted higher limits by statute as of July 1, 1956. The grandfather clause has been controversial since its inception and has been a primary reason for variation in allowable gross vehicle and axle weights among States up to the present.

Congress responded to the increased financial needs of Interstate construction by increasing highway-use taxes in the Federal-Aid Highway Act of 1961. Also, user charges were restructured at this time based upon the first highway cost allocation study, completed in 1961. The heavy-vehicle use tax doubled to $\$ 3$ per 1,000 pounds over 26,000 pounds gross vehicle weight. This reflected the cost allocation study results, which showed that heavier trucks were not taxed to the full equivalent of the cost occasioned by that class of vehicles. This conclusion was reinforced by the results of the second highway cost allocation study, completed in 1970, which estimated that trucks operating over 75,000 pounds gross weight paid only 60 percent of the highway costs attributable to such heavy vehicles.

In 1974, responding to declining truck productivity resulting from rising fuel prices and the 55 mile per hour (mph) national speed limit, Congress increased Federal weight limits. The Federal-Aid Highway Amendments of 1974 increased single and tandem axle limits to 20,000 and 34,000 pounds, respectively, and gross vehicle weight to 80,000 pounds. For the first time, Congress imposed the so-called "bridge formula" which limited gross vehicle weight based on the number and spacing of axles on the vehicles. These limits were again permissive maximums, allowing continuation of lower state weight limits. The amendments also added a second grandfather clause which exempted State limits already in effect from the new bridge formula maximums.

As a result of the permissive nature of the weight maximums and the two grandfather clauses, State weight limits varied considerably after 1974. Five States with limits below the Federal maximum were located along the Mississippi Valley in proximity to one another. These became known as the "barrier States" since it became nearly impossible to avoid them for crosscountry shipments.

The weight limit increase was passed by Congress in 1974 to enhance trucking efficiency but with the realization that the serviceability of the 
Federal-aid highway system would be reduced, some reports indicating by as much as 20 percent. This raised new concern in Congress that States adequately enforce the limits to prevent overweight vehicles. Thus, Congress added a provision in the 1974 law to require States to certify that they are enforcing Federal size and weight limits. This was strengthened by the Surface Transportation Assistance Act of 1978, which further authorized the U.S. Department of Transportation (DOT) to require such information as was considered necessary for State certification, with a penalty for noncompliance of 10 percent of apportioned State highway funds. Congress also directed the Federal Highway Administration (FHWA) to study the need for nationally uniform truck size and weight limits, and to begin a third comprehensive highway cost a) location study.

It was becoming clear during the late 1970's that large portions of the Federal-aid system of highways and bridges were in need of repair or reconstruction. Congress addressed the massive financing needs created by the wearing out of the Interstate system by substantially increasing most highwayrelated taxes in the Surface Transportation Assistance Act (STAA) of 1982. The structure of the increased taxes was influenced by results of the third, and most recent, highway cost allocation study (DOT, 1982). Once again, heavy vehicles were shown to underpay highway cost assigned to them by the study methodology. This was at the expense of other vehicle classes, such as single unit trucks, which were shown to overpay in order for user fees to fully cover all costs of the highway system. Accordingly, the diesel fuel tax was increased from $4 \$$ to $9 \$$ per gallon, and the heavy-vehicle use tax became graduated up to a maximum of $\$ 1,900$ per vehicle weighing 80,000 pounds or more (effective JuTy 1, 1988). Even with this increase in the heavy-vehicle component of the highway trust fund tax structure, trucks weighing over 75,000 pounds still only pay an estimated 66 percent of allocated cost. An even more important and pertinent feature of the 1982 STAA is that it established some uniformity in size and weight limits for the Interstate highway system. States were required to allow weight limits up to the Federal limits established in 1974, or lose Federal funds. Despite this legislation, State weight limits are still not entirely uniform because of the two previous grandfather provisions and various statutory exceptions. 


\subsection{FEDERAL ROLE}

The next two sections provide an overview of the Federal and State roles in administering and enforcing weight limitations on the Interstate system. This is useful background for the discussion of issues later in this report.

\subsubsection{Statutes/Regulations}

The Surface Transportation Assistance Act of 1982 (Public Law 97-424, January 6, 1983) brought about numerous changes to the Federal-aid highway system. Section 133 of the STAA addressed vehicle weight limitations on the Interstate system. The three areas it covered were (1) uniform weight limits, (2) exceptions to these limits, and (3) access to the Interstate system from other highways. These statutory provisions were incorporated as Part 658 of Title 49 of the Code of Federal Regulations (49 CFR Part 658) on June 5, 1984.

The STAA did not change the existing maximum weight limits of 20,000 pounds for single axles, 34,000 pounds for tandem axles, and 80,000 pounds gross vehicle weight. It did, however, identify these same weights as minimum limits that each State must allow, or face the prospect of losing Federal highway funds. The STAA also continued the application of the bridge gross weight formula for determination of maximum allowable gross weights. The bridge formula is discussed in further detail in Section 3.1.

There are two exceptions to the weight limits provided by Section 133 of the STAA. The first is for loads which cannot be "easily dismantled or divided and which have been issued special permits in accordance with state laws." The second exception grandfathers State weight limits already in existence at the time new Federal limits were passed in 1956 and 1974.

The third area covered by Section 133 of the 1982 STAA is ensuring "reasonable" access to and from the Interstate system. The STAA restricts the States from denying motor vehicles access to "terminals, and facilities for food, fue1, repairs, and rest" when located off the Interstate system. Appendix $A$ of 49 CFR Part 658 identifies an extensive national network of 
highways that have been authorized by States for vehicles operating within the new length and width allowances. However, the national network does not apply to weight limits. This has been the subject of some misunderstanding. The uniform Federal weight limits apply only to the Interstate system and not to the entire national network of highways designated in 49 CFR Part 658.

As previously mentioned, the Surface Transportation Assistance Act of 1978 directs each State to certify annually that it is enforcing State laws on maximum size and weights on the entire Federal-aid highway system, including the Interstates. Implementing regulations are codified in 49 CFR Part 657.

\subsubsection{Administration}

2.2.2.1 Federa1 Highway Administration. The Federal Highway Administration (FHWA) is located within the U.S. DOT and administers the overall Federal-aid highway system. Although the agency has great influence over the development and funding of the Federal-aid highway system, it has relatively little power over highway size and weight limits. This has long been recognized as primarily a State function. In 1978, Congress strengthened the reporting and penalty provisions relating to inadequate State enforcement. Some States have been threatened with loss of funding, but none have ever lost any Federal highway funds because of their inattention to Federal weight limits.

The FHWA does perform several functions in the area of size and weight control. It promulgates regulations such as 49 CFR Part 658. The agency also provides information and conducts promotional activities to keep States informed on size and weight issues. Most important1y, FHWA monitors the State enforcement programs and permit procedures, as directed by the 1978 STAA.

Congress requires the FHWA to submit an annual report containing enforcement certifications from each State and an inventory of State penalty systems for overweight violations. The FHWA also includes an inventory of State special permit practices in the annual report. The reports, titled Overweight Vehicles - Penalties and Permits, an Inventory of State Practices, are submitted to Congress around November of each year. 
The FHWA's Office of Traffic Operations published criteria for FHWA approval of State certifications in 1979. Each State is required to submit documentation to support its contention that it has an effective weight enforcement program. The information is reviewed for technical and legal sufficiency by various offices within FHWA. If the State certification is not supported by adequate data, FHWA can take action to withhold 10 percent of the State's highway funds. Only in a few cases has FHWA not approved the State certifications. In these cases, warning letters to the Governor's office led to the eventual submission of required data or information to satisfy FHWA.

2.2.2.2 Other Federal Agencies. The FHWA has no authority to monitor other Federal agency shipping practices or truck weight policies. However, since the General Accounting Office report (GAO, 1979), which strongly criticized the shipping practices of various Federal agencies, the FHWA has taken steps to increase the awareness of other agencies on this issue. GAO documented cases of substantial overweight shipments of such items as logs by the Forest Service, coal by both the Tennessee Valley Authority and DOE's Oak Ridge National Laboratory, bulk ores by the General Services Administration, and rocks by the Corps of Engineers. In response to Congressional pressure, the Secretary of Transportation wrote letters in 1978 to 12 Federal agencies, requesting their help in limiting overweight shipments and setting the example for States.

It should be noted that States see a dual standard for the Federal government in this regard. On the one hand, the DOT and Congress continualiy pressure State agencies on weight control, while on the other hand, States frequently encounter overweight carriers operating under contract to a Federal agency.

\subsubsection{DOE Overweight Truck Policy. In February of 1979, the} Secretary of Energy responded to the DOT letter on Federal agency truck weight policies and promised to investigate shipment policies of DOE field offices and installations (Schlesinger, 1979). The letter also stated that DOE intended to adhere to the 80,000 pound limit provided by most States at that time except for the movement of "strategic construction components to remote sites not served by railroad or water carriers." 
In July of 1979, DOE received a critical letter from the House ways and Means Subcommittee on Oversight (Gibbons, 1979). It stated that Congressional hearings held from 1977-79 on overweight trucks revealed that Federal agencies "are among the worst offenders in failing to discourage truck overweight among their contractors and grantees. One such agency is the Department of Energy's Oak Ridge Operations."

DOE responded to the oversight subcommittee that it was already taking actions to eliminate such practices at Oak Ridge and at other DOE locations. DOE's Secretary of Environment then wrote letters to the manager of each DOE Operations Office, requesting corrective action to curtail overweight shipments to and from respective facilities.

The official DOE policy on overweight truck shipments is stated in Section 4(c) of DOE Order 1540.1 (DOE, 1982):

Size and Weight Limitations for Highway Shipments. Motor carrier shipments shall conform to State and local laws, regulations, and ordinances relating to weight and size limitations. No vehicular movement which exceeds any State's legal-weight or size limitation shall be undertaken over public highways unless prior permission is formally granted by the State concerned. The Department or Department's contractor support of a carrier requesting such permission may be furnished only after a determination that it is not practical to divide the load into smaller lots or feasible to move the material by other means of transportation.

This policy has been reiterated on a number of occasions. In response to an inquiry from a manufacturer of casks in July 1983, DOE (Garrison, 1983) stated that based on its own policy and Congressional scrutiny "it is most difficult for the DOE to support repetitive overweight transports via motor freight. This can only be done with proper justification...". DOE policy specifically relating to overweight truck shipments of nuclear waste was spelled out quite recently in 1984 by DOE's Office of Defense Programs (Hoover, 1984). The policy reiterates DOE Order 1540.1 and the lead authority of the State and local governments on permits:

The DOE policy on overweight/oversized shipments is to adhere closely to all applicable Federal, State, and local laws and regulations on movements of materials to or from our operating facilities whether for our own account or on behalf of our contractors. The Department recognizes the 
State as the permitting authority for commercial shipments requiring overweight or oversized equipment.

The DOE's design for radioactive material shipment casks will continue to balance the benefit of reducing the number of overall shipments with the possible highway road damage caused by overweight vehicles. The DOE will informally request appropriate State officials' review and comment on the design of any overweight or overdimensional equipment.

\subsection{STATE ROLE}

The State and local governments have principal responsibility for all roads and highways within their jurisdiction. This has always been the case, even with the tremendous involvement of the Federal government since 1916 in financing the Federal-aid system. Although State and local governments provide only 10 percent matching funds for Interstate construction and about 25 percent matching funds for other Federal-aid highways, this represents a very substantial annual investment relative to the size of individual State budgets. In addition, State and local governments have full responsibility for design, construction, reconstruction, maintenance, and enforcement costs of all non-Federal-aid highways, which represent 70 percent of the total highway mileage in the United States. To finance this investment, almost every State has highway user fees similar to those at the Federal level (e.g., excise taxes on fuel, autos, trucks, tires, and heavy-vehicle user charges) and about half have set up a highway trust fund similar to that at the Federal level.

Thus, State and local governments contribute substantially to the total national highway system with their investment comprising about 50 percent of all highway expenditures in the United States. Consequently, State and local officials, just as Congressional and Federal officials, believe they must protect their investment by limiting vehicle size and weights. However, there is considerable disagreement among State officials as to the kind of protective limits that are necessary. 


\subsubsection{Statutes/Regulations}

Every State has its own enabling legislation that governs vehicle size and weights allowable on its highways. Virtually all States had enacted limits well before the first Federal limits were prescribed in 1956. Implementing regulations have also been published in each State. In addition, almost every State has a set of administrative procedures that apply specifically to the application and processing of special permits for vehicles which exceed the State size and weight limits.

Prior to 1982 , seven States had not enacted an 80,000 pound gross vehicle weight in accordance with the Federal permissive maximum for Interstate highways. These barrier States passed new laws increasing weight allowances from 73,280 pounds to the 80,000 pound limit for Interstate highways within their jurisdictions to avoid loss of Federal funds dictated by the 1982 STAA. Three States, New Mexico, Hawaii, and Michigan, were specifically exempted by the STAA for various reasons and retained their previous gross vehicle weight (GVW) limit. These reasons will be addressed in Chapter 3. State laws governing noninterstate highway weight limits were not affected by the STAA and remain nonuniform.

\subsubsection{Administration}

Administration of size and weight programs is divided among several agencies in most States. Generally, agencies responsible for establishing regulations and procedures and for issuing permits are the State departments of transportation or highways. These same agencies also are usually responsible for administering highway construction and maintenance contracts, and developing funding strategies to fully capitalize on available Federal matching funds.

Responsibility for enforcement, however, is usualiy placed upon State departments of public safety or the State police. These agencies levy penalties and fees, and conduct compliance activities in 24 States. Another 12 States rely on the departments of highways or transportation for enforcement. The States have been criticized for this fragmented approach to highway administration and the FHWA, among others, has recommended consolidation of 
such activities into one agency to enhance both administration and enforcement of size and weight 1 imits.

The two key functions at the State level, with respect to weight limits, are enforcement and permitting. Weight enforcement is discussed in the next section while permitting is addressed in detail in Chapter 3 .

\subsubsection{Enforcement}

Each State is responsible for the enforcement of State and Federal laws pertaining to the weight of vehicles operating within its borders. Enforcement policy varies considerably in both stringency and method of operation. The enforcement strategy depends upon the type of weighing-scale operations utilized, and the manner in which scales are deployed. There are four types of scale systems: portable, semiportable, fixed, and weigh-inmotion (WIM).

About 95 million trucks were weighed by State weight-enforcement authorities in 1983. Fixed-scales accounted for 85 million weighings (94 percent), and a 11 other scales accounted for only about 10 million weighings. However, the number of WIM-scale weighings increased from 0.5 million in 1982 to 2 million in 1983. It appears this trend will continue as FHWA continues to support financially the development and use of WIM scales.

Each State has minimum and maximum limits on overweight vehicle citations. Generally, the amount of the fine is a function of the amount of overweight. Some States also include the distance traveled by an overweight truck as a factor to compute fines. The amounts vary greatly. As an example, based upon a review of State penalties, the citation for a vehicle which is overweight by 12,000 pounds could range from a low of $\$ 75$ in one State to $\$ 2,850$ in another State. A total of 587,513 overweight citations were issued by States in 1983, a 10 percent increase over 1982. Of the total, 49 percent of the citations were for axle weight violations, 24 percent for gross vehicle weight violations, and 17 percent for bridge formula violations. 


\subsubsection{0ther Weight Control Authorities}

Although State governments have principal responsibility for vehicle size and weight control in the United States, some local governments and toll facilities have autonomous authority to establish and enforce their own limits.

2.3.4.1 Local Governments. A substantial percentage of roads and highways is under control of local governments rather than State governments. The GAO study (GAO, 1979) indicated that as much as 35 percent of the Federalaid highway system is under local control and 79 percent of total roadway mileage in the United States is under local control. The division of responsibility among States, counties, townships, and municipalities with respect to vehicle size and weight control is vague.

Generally, counties and cities are responsible for weight enforcement within their boundaries, although a survey of State weight officials in the GAO study (GAO, 1979) indicated that less than 40 local governments had any enforcement programs. Some cities also have the legal authority to set weight limits on certain roadways, or to prescribe local truck routing.

\subsubsection{Toll Facilities. Privately operated toll roads, bridges,} and tunnels exercise their own limits on vehicle size and weight. Federal and State weight laws usually do not apply to these facilities. They set their own routine limits, decide on maximum allowable permit 1 imits, and prescribe other restrictions for overweight vehicles as they see fit. Even some toll facilities operated by State governmental units have autonomy from the State weight authorities.

Generally, weight limits prescribed by turnpike authorities are lower than current Federal limits. They typically range from 70,000 to 73,500 pounds. However, under certain conditions, these authorities issue permits routinely for vehicle weights that exceed the 80,000 pound Federal limit. Restrictions also apply on night and weekend travel. Since some of the turnpikes are actually part of the designated Federal-aid highway system, a carrier often has to obtain permits from these facilities as well as from State governments. 


\subsection{EFFECT OF VEHICLE WEIGHT \\ ON HIGHWAYS AND BRIDGES}

Federal and State officials are concerned with controlling vehicle weights because of the direct relationship between vehicle weights and the serviceability of highways and bridges. These facilities are designed to accommodate certain axle loadings and gross weights. If these design loads are exceeded, the service lives of highways and bridges are shortened, thus requiring maintenance or reconstruction expenditures sooner than anticipated. This section provides an overview of the relationship between vehicle weight and damage to highways and bridges.

\subsubsection{Highways}

Highways are actually layered pavement structures usually consisting of (1) the surface layer of flexible (asphalt) or rigid (concrete) construction; (2) the base, which underlies the surface layer and is composed of gravel, crushed stone, or sand; and (3) the subbase, composed of any number of materials to provide support for the base and surface layers. Deterioration of these pavement structures can be caused by many factors including weather, lack of maintenance, natural aging of materials, and traffic conditions.

Pavement structures are designed to maintain a certain level of serviceability for projected traffic loadings over the service life. This will determine the type of material and the thickness of the layers for the pavement. The Interim Guide for Design of Pavement Structures (AASHTO, 1972), the principal reference for most highway designers, expresses the mathematical relationship between pavement thickness, serviceability, and traffic loadings based upon extensive road tests conducted in the 1950's and 1960's. Based upon AASHTO procedures, the loss in pavement serviceability (i.e., the amount of highway damage over time) caused by a given axle load can be mathematically derived, as will be illustrated in Chapter 4.

The AASHTO data indicate that highway damage increases exponentially as the axle weight increases. For example, the damage caused by a 26,000pound truck is 200 percent greater than a 20,000 pound truck of the same type, even though the weight increased only 30 percent. The GAO truck weight study 
(GAO, 1979) uses the example that a single legal-weight 18-wheel tractortrailer combination truck causes the equivalent highway damage of 9,600 medium-size automobiles based upon AASHTO data. However, increasing either the number of axles or the spacing between axles, can greatly diminish the effect of increasing vehicle weight. The relationship between the number and spacing of axles and highway damage is discussed in more detail in Chapter 4.

\subsubsection{Bridges}

Bridge design is based upon required horizontal and vertical clearances, materials of construction, environmental conditions such as climate, and projected traffic loads. Bridge members must be strong enough to support the weight of the heaviest vehicles likely to cross, as well as the weight of the bridge itself. Thus, a crucial element of bridge design, as with pavement design, is the projected amount and type of traffic. Unlike pavements, however, the primary consideration for bridge damage is the number and spacing of axles rather than individual axle weights. In general, the more axles and the greater spacing between axies, the less stress will be created on the bridge for a given load.

AASHTO standards are used for the design of most bridges in the United States (AASHTO, 1977). The principal traffic-related design loading used by AASHTO for the Interstate system is called the HS2O truck loading. The vehicle used to represent maximum bridge stress is 72,000 pounds on 3 axles with spacing of 14 feet between axles 1 and 2, and 14 to 30 feet between axles 2 and 3 . The axle spacing for this load was chosen to simulate the worst possible condition for the range of trucks operated on the Interstate system. Lesser traffic design loads used by AASHTO for non-Interstate bridges are called H2O, HS15, and H15. The HS15 load is the minimum design recommended by AASHTO for highways which may experience heavy truck traffic.

There is great concern over the status of bridges both on and of $f$ the Interstate system. Table 1 illustrates that many of the 235,000 bridges on the Federal-aid highway system are not designed for heavy trucks, especially overweight trucks. The GAO (GAO, 1979) contends that as many as 92 percent of bridges on the Federal-aid system are not strong enough to carry the current legal-weight of 80,000 pounds without some reduction in service 
TABLE 1. HEAVY TRUCKS AND BRIDGE DESIGN STANDARDS

\begin{tabular}{lcc}
\hline \hline & $\begin{array}{c}\text { Interstate } \\
\text { System }\end{array}$ & $\begin{array}{c}\text { All Federal- } \\
\text { Aid Highways }\end{array}$ \\
\hline $\begin{array}{l}\text { Bridges recommended by AASHTO for } \\
\text { heavy trucks (HS-15 load or higher) }\end{array}$ & $95.9 \%$ & $50.5 \%$ \\
$\begin{array}{l}\text { Bridges not recommended by AASHT0 } \\
\text { heavy trucks (H-15 load or lower) }\end{array}$ & $\mathbb{4 . 1 \%}$ & $\underline{49.5 \%}$ \\
\hline
\end{tabular}

Source: DOT Investigation of Truck Size and Weight Limits, August 1981 a.

life. In addition, and not shown in Table 1, are non-Federal-aid bridges, which typically are designed to a lower standard.

Bridges are protected from overstress caused by heavy vehicles by the use of various "bridge formulas." These are mathematical relationships that define the maximum load that can be carried on any group of two or more consecutive axles, as a function of the number of axles and the distance between the two extreme axles in the group. The Federal Gross Weight Bridge Formula B, presented in the Chapter 3, became the legal limit for Interstate highways with the 1974 STAA. The basic idea of the bridge formulas is that the maximum load can be increased as the length of the axle group is increased. The bridge formulas are necessary because even trucks that are within legal axle and gross weight limits can cause serious bridge overstress if the axles are too close for a given weight. In addition to legal limits prescribed by the bridge formulas, States can protect particularly weak bridges by individual weight and speed posting, and by overweight permit limitations. 


\subsection{STATE WEIGHT LIMITS AND PERMIT OPERATIONS}

\subsection{STATE WEIGHT LIMITS}

One reason for the Surface Transportation Assistance Act. (STAA) of 1982 was to create uniform size and weight limits on the Interstate system. This was only partially successful for weight limits as discussed below.

\subsubsection{Interstate Highways}

A11 50 States have adopted Interstate highway weight limits at least as high as the uniform weight limits prescribed by the 1982 STAA. These limits are given in Table 2.

The uniform weights identified in Table 2 include all allowable tolerances, unless States had previously authorized tolerances in 1956 that are covered by the grandfather clause, as explained below (Section 3.1.2). Tolerances are established by many States to account for possible inaccuracy of weighing scales. Prior to the STAA of 1982, many states had Statutory tolerances on both axle weights and gross vehicle weights. These ranged from

TABLE 2. UNIFORM VEHICLE WEIGHT LIMITS ADOPTED BY STATES PURSUANT TO THE SURFACE TRANSPORTATION ASSISTANCE ACT OF 1982

\begin{tabular}{ll}
\hline \multicolumn{1}{c}{ Type of Limit } & \multicolumn{1}{c}{ Limit Allowable } \\
\hline Single axle & 20,000 pounds \\
Tandem axle & 34,000 pounds \\
Gross vehicle weight & 80,000 pounds \\
Axle groups & $\begin{array}{l}\text { Bridge Gross Weight Formula B (1imits overall gross } \\
\text { weight to } 80,000 \text { pounds or less depending on } \\
\text { axle spacing and number of axles) }\end{array}$
\end{tabular}

Source: Surface Transportation Assistance Act of 1982. 
2 percent to as much as 13 percent of the limits identified by various States. Such tolerances are still authorized by most States for non-Interstate highways.

3.1.1.1 Axle Weight Limits. A key factor in highway damage is the weight transmitted to the road surface by individual vehicle axles. Obviously there is a need to limit individual axle weights regardless of overall gross vehicle weight. Two types of axles, single and tandem, are subject to limits in a11 States.

The single axle weight is defined as the total weight transmitted to the road by a 11 wheels whose centers may be included between two parallel transverse vertical planes, 40 inches apart, extending across the full width of the vehicle. The single axle weight limit of 20,000 pounds applies to all individual axles, even if the axle is part of a set of axles in tandem.

A limit of 34,000 pounds is prescribed for tandem axles. Tandem axles consist of two or more successive axles that are equally spaced and, in some cases, articulated from a common attachment to the vehicle or trailer. Individual axles within the tandem may be attached to the vehicle at the same point and, with the help of a load equalizing device, the weight is distributed equally among the axles. The Federal definition of a tandem axle weight is the total weight transmitted to the road by two or more consecutive axles whose centers may be included between parallel transverse vertical planes spaced over 40 but not more than 96 inches apart, extending across the ful 1 width of the vehicle. Some States allow higher weight for a tandem axle consisting of three axles. The weight allowed for these tridem axles varies from 42,000 to 54,000 pounds.

Some States have special restrictions relating to vehicle weight other than single and tandem axle limits. These are shown in the "other" column in Table 11, the State weight table, presented in Section 3.3. At least four States have legal limits on the steering axle weight. The limits range from 12,000 to 13,000 pounds. Half of the States also prescribe maximum tire pressure. The limits range from 550 pounds per inch of tire width, to 800 pounds per inch of tire width. 
3.1.1.2 Gross Vehicle Weight and Bridge Gross Weight Formula. The Federal GVW limit was 73,280 pounds until 1974. This weight was based partly upon the consideration of bridge design procedures adopted in 1944. As previously discussed, bridges are designed to accommodate a reference design vehicle with specific axle spacing and gross weight. Vehicles that exceed the reference design vehicle specifications (e.g., that have shorter axle spacing or higher gross weight) will overstress bridges. This will eventually cause a bridge to need replacement. When Congress increased the GVW 1 imit in 1974, it was concerned about bridges which were designed under the 1944 procedures. It adopted the Bridge Gross Weight Formula B (now called the Federal Bridge Formula, or just the bridge formula) to protect such bridges. Some States are allowed to use other bridge formulas or specifically applied limits in spite of the 1982 STAA. This is covered in Section 3.1.2. The following discussion explains the federally prescribed Bridge Formula $B$ which is presented in Table 3.

Federal and corresponding State regulations provide that any consecutive two or more axles may not exceed the weight computed by the Bridge Gross Weight Formula even though single axles, tandem axles, and gross weights are under the legal 1 imit. The formula must be applied and satisfied for all possible axle combinations on a vehicle. This can become quite complex.

TABLE 3. BRIDGE GROSS WEIGHT FORMULA B

No vehicle or combination of vehicles may be operated on the Interstate highways when the gross weight on two or more consecutive axles exceeds the limitations prescribed by the following formula:

$$
W=500\left(\frac{L N}{N-1}+12 N+36\right)
$$

where $W=$ overall gross weight on any group of two or more consecutive axles to the nearest 500 pounds, $L=$ distance in feet between the extreme of any group of two or more consecutive axles, and $N=$ number of axles in the group under consideration.

Source: Surface Transportation Assistance Act of 1982. 
An illustration of the application of this formula to a typical 18-whee 1 tractor-trailer combination is presented in Appendix B. Of particular importance to many States are the so-called inner and outer bridge weights. The inner bridge weight limit applies to the axle group formed by the load carrying axles, i.e., from the first drive axle to the last trailer axle. The outer bridge weight limit applies to the total axle group, i.e., from the first to the last axle on the entire vehicle combination. These are also ilustrated in Appendix B.

The net result of the bridge gross weight formula is to create a series of maximum weight limits based upon the number of axles and the distance between axles. Table 4 is based upon the application of the Federal bridge formula for vehicles with 2 to 9 axles and axle spacing of 4 to 60 feet. There are two important points concerning this chart. First, a line has been drawn in step-wise fashion for each column where the application of the formula results in 80,000 pounds. This is the absolute maximum authorized by the 1982 STAA. The actual legal-weight limit in many cases is less than 80,000 pounds, depending upon the number and spacing of axles.

Note also that it is possible for vehicles to operate up to 105,500 pounds gross weight (and higher) and still meet the bridge formula. In other words, with the right combination of axles and spacing between the axles, vehicles could substantially exceed the 80,000 pound limit, if allowed under special permit, without creating unacceptable bridge damage.

The second point about this table concerns an exception from the bridge formula provided by the STAA. This is identified in Table 4 under the column for 4 axles. Federal and State laws allow two consecutive sets of tandem axles to carry a gross load of 34,000 pounds each, if the distance

between the axles is 36 feet or more. Thus, the total weight allowed for the two tandem axles (total of 4 axles) is 68,000 pounds rather than the weight shown in the brackets in the table.

\subsubsection{Exceptions From Interstate Limits}

Vehicle weight limits are now uniform from the standpoint of the minimum weight which must be allowed by States on the Interstate system. However, maximum allowable weights are not uniform because of several 
TABLE 4. ALLOWABLE GROSS VEHICLE WEIGHTS

UNDER THE FEDERAL BRIDGE FORMULA

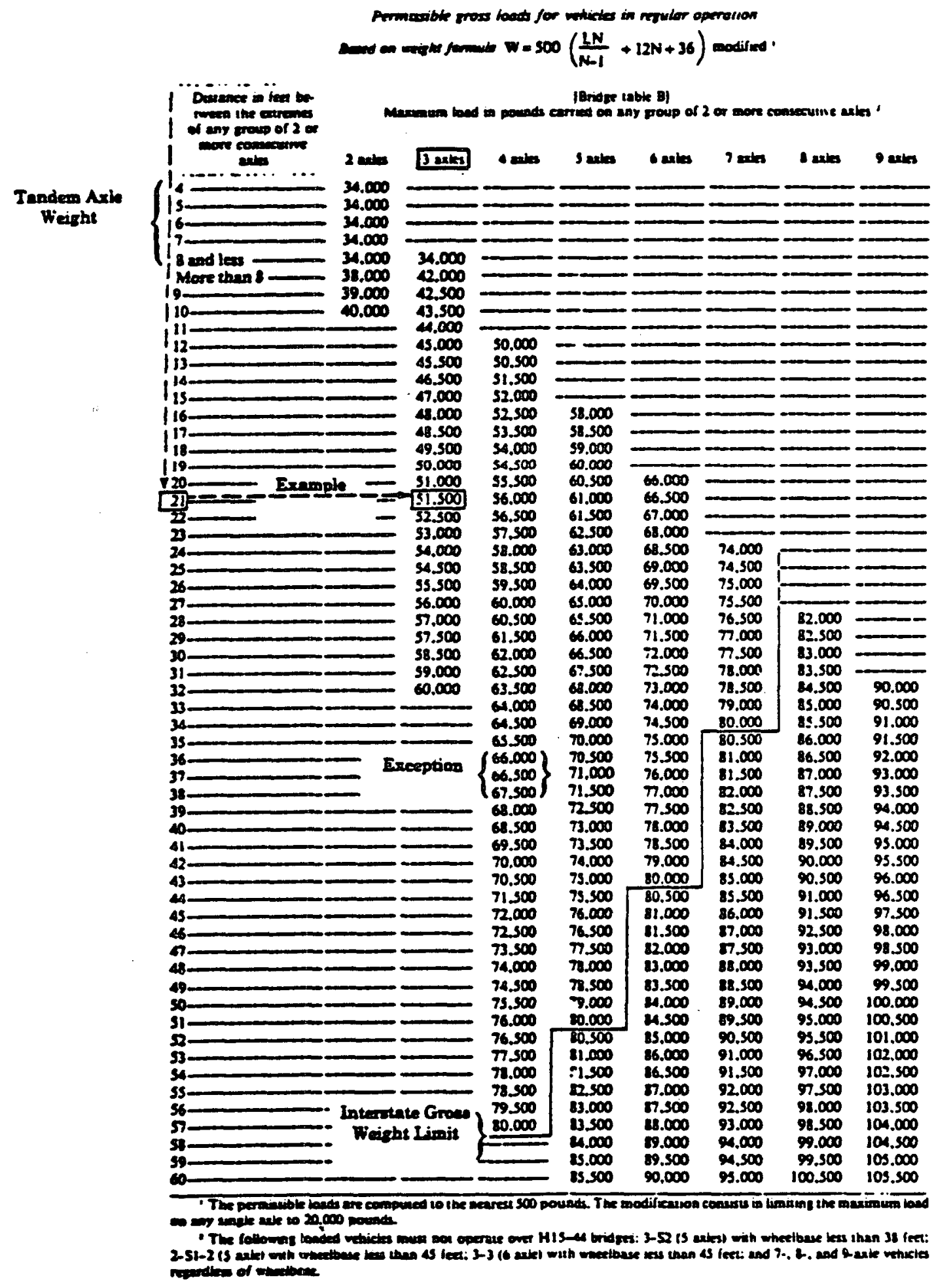

Source: Federal Highway Administration. 
exceptions provided by Congress in the 1982 STAA. These relate to grandfather provisions, and the authority of the States to issue special permits. Table 5 presents these exceptions which are further discussed below.

TABLE 5. STATE WEIGHT LIMITS WHICH EXCEED FEDERAL LIMITS BY EXCEPTIONS FROM THE SURFACE TRANSPORTATION ASSISTANCE ACT OF 1982

\begin{tabular}{|c|c|c|c|}
\hline Type of Exception & Authority & $\begin{array}{l}\text { Number of } \\
\text { States }\end{array}$ & $\begin{array}{l}\text { Highest Weight } \\
\text { (pounds) }\end{array}$ \\
\hline \multicolumn{4}{|l|}{ 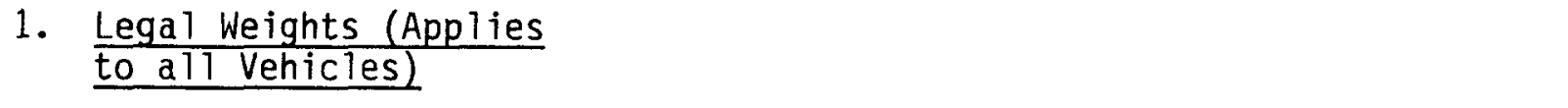 } \\
\hline $\begin{array}{l}\text { Single Axle } \\
\text { Tandem Axle } \\
\text { Gross } \\
\text { Axle Groups }\end{array}$ & $\begin{array}{l}1956 \text { Grandfather } \\
1956 \text { Grandfather } \\
1982 \text { Grandfather } \\
1974 \text { Grandfather }\end{array}$ & $\begin{array}{l}15 \\
16 \\
3 \\
10-15^{1}\end{array}$ & $\begin{array}{l}24,000 \\
44,000 \\
149,000 \\
\text { Varies }\end{array}$ \\
\hline \multicolumn{4}{|l|}{$\begin{array}{l}\text { 2. Divisible Loads } \\
\frac{\text { (Applies to }}{\text { Specific Commodities) }}\end{array}$} \\
\hline $\begin{array}{l}\text { Statutory Exemption } \\
\text { State Permit }\end{array}$ & $\begin{array}{l}1956 \text { Grandfather } \\
1956 \text { Grandfather }\end{array}$ & $\begin{array}{l}13 \\
23^{2}\end{array}$ & $\begin{array}{l}\text { Varies } \\
\text { Varies }\end{array}$ \\
\hline \multicolumn{4}{|l|}{$\begin{array}{l}\text { 3. Nondivisible Loads } \\
\text { (Applies to any } \\
\text { Commodity Not } \\
\text { Easily Dismantled) }\end{array}$} \\
\hline State Permit & 1982 Exception & 50 & Varies \\
\hline
\end{tabular}

1 The number of States that have legitimate grandfather rights to allow axle spacing requirements different from the Federal Bridge Formula is not known precisely, but it probably ranges from 10 to 15 states (based upon an interview with Harold Brown, FHWA).

2In 1983, 23 States issued divisible load permits. However, the number of States which have legitimate grandfather rights to do so is being reviewed and is the subject of litigation.

Source: Battelle analysis. 
3.1.2.1 Grandfather Provisions. State maximum weight limits that exceeded Federal limits and that were in effect on July 1, 1956 are exempt from the Federal uniform weight limits. This is a result of the first grandfather clause. These grandfathered limits all apply to single and tandem axles and include tolerances that were in effect in 1956. For example, if a State had a limit of 20,000 pounds plus 10 percent tolerance, its limit of 22,000 pounds is covered by the grandfather clause. The result is that 15 States (including the District of Columbia) have single axle weight limits in excess of 20,000 pounds, and 16 States have tandem axle weight limits in excess of 34,000 pounds.

The 1982 STAA also exempts State gross weight limits based on bridge formulas or tables, or axle spacing requirements that were in effect at the time of enactment of the 1974 Federal-Aid Highway Amendments. This is known as the second grandfather clause. Thus, although all but three States have adopted the absolute 80,000 pound GVW 1imit, this exemption effectively allows different gross vehicle weights for given axle spacings for some States. It is not clear how many States have legitimate claims to grandfather rights for their axle spacing requirements. As shown in Table 11, at least 10 States use another formula, table, or their own specific limits for some portion of Interstate weight limits. The Federal Highway Administration (FHWA) maintains that the matter is currently under review. Nevertheless, the net result of the two grandfather clauses is that many States have legal maximum weights in excess of the so-called uniform weight limits. This is shown in Table 5 .

Another type of exception covered by the 1956 grandfather provision pertains to divisible loads (i.e., loads which can be easily divided or dismantled to reduce weight). The grandfather clause covers statutory exemptions and special permits for divisible loads if the State had already provided for such before July 1, 1956. A few States even insist that the grandfather clause applies even if the State had the legal authority to issue exemptions or permits but had not yet exercised that authority prior to 1956 . This is another controversial issue being addressed by the FHWA and Congress.

The General Accounting office (GAO) has reported that 13 States claim valid statutory exemptions that apply to specific commodities only. These commodities are usually of great local or regional economic importance and include farm products, timber, cement, petroleum, coal, and others. In 
addition, there were 23 States which issued divisible load permits in 1983 . The number of States which do so under legitimate grandfather authority is currently being evaluated by the FHWA.

\subsubsection{Nondivisible Load Special Permits. The second major} exception from the uniform weight limits authorized by the 1982 STAA is for loads that cannot be easily dismantled or divided and that have been issued a special permit by each State in whose jurisdiction the vehicle is operating. These are commonly called nondivisible load permits. All 50 States issue such permits for a wide variety of qualified loads and for a wide range of weights.

The distinction between a divisible and nondivisible load should be noted here for it promises to be an important determination for overweight nuclear shipments. If a spent fuel cask that contains more than one fuel element and is heavy enough to result in an overweight vehicle is interpreted to be a nondivisible load, then State permits can conceivably be obtained for the movement. However, if it is interpreted to be a divisible load, it would not presently be authorized in some States by either the 1982 STAA weight limits, or the exceptions. This will be addressed again in Section 5.2.1.

\subsubsection{Noninterstate Highway Limits}

The Federal weight limits apply only to the Interstate highway system. This leaves the remainder of the Federal-aid highway system and a 11 non-Federal-aid roadways subject to individual State weight limits. Noninterstate highways will play an important role in the commercial repository program. Most reactors are not on the Interstate system and the storage or disposal site may be in a relatively remote area well off the Interstates. Thus, State policies and weight limits which apply to noninterstates may become just as crucial as those that apply to the Interstates.

Table 6 shows the deviation between State gross weight limits for noninterstate highways and Interstate highways.

The six States identified in Table 6 with noninterstate weight limits below 80,000 pounds include the barrier States that had retained the 73,280 pound limit for Interstates until the 1982 STAA. Most of the States which allow vehicle weights in excess of 80,000 pounds are western States. 
TABLE 6. DEVIATION OF NONINTERSTATE GROSS VEHICLE WEIGHT LIMITS FROM FEDERAL LIMIT

\begin{tabular}{lcc}
\hline \hline $\begin{array}{c}\text { Deviation From } \\
\text { Federal Limit } \\
\text { (pounds) }\end{array}$ & $\begin{array}{c}\text { Number of } \\
\text { States }\end{array}$ & $\begin{array}{c}\text { Weight Limits } \\
\text { (pounds) }\end{array}$ \\
\hline Below 80,000 & 6 & 73,280 \\
At 80,000 & 37 & -- \\
Above 80,000 & 8 & 84,000 to 149,000 \\
\hline
\end{tabular}

Source: Federal Highway Administration.

It should be noted that many States have their own bridge formulas or tables, which may result in maximum limits that are below Table 6 limits because of the number and spacing of axles. The State weight table (Table 11) indicates that as many as 19 States apply limits other than Formula B limits for all or a portion of their noninterstate highway system.

\subsection{STATE PERMIT OPERATIONS}

State policy and procedures regarding overweight vehicle permits will become extremely important for the repository program if an overweight truck cask is developed. Consequently, State permit operations need to be addressed in some detail. The narrative in this section is intended to give the reader an overview of the state permit processes.* Specific details on each State permit program have been extracted from numerous sources and are presented in Appendix A. Permit operations and restrictions relating to toll facilities are presented separately in Appendix $A$ but are not discussed in this section.

*Some of the data and information presented throughout Section 3.2 is based upon the Transportation Research Board (1980) National Cooperative Highway Research Program Synthesis Report 68 (NCHRP68), which was most recently updated in 1980. 


\subsubsection{Types of Permits}

In general, there are two types of weight control permits: singletrip permits and multiple-trip permits.

A single-trip permit is issued for a single, one-way, or round trip, as specified in the laws of each State. Most States issue single-trip permits that are valid for 3 to 5 days. Single-trip permits that are valid for less than one week are issued by 35 States, and permits that are valid for one to two weeks are issued by 11 States. The District of Columbia and North Carolina issue 30-day single-trip permits. An extension of a time period equal to the length of the permit will be granted by 28 States if a shipment cannot be made within a permit period because of an unforeseeable situation such as bad weather.

Multiple-trip permits cover numerous movements within a certain period of time. Generally, they range from two weeks to one year. Multipletrip permits are typicaliy issued to manufacturers, contractors, and others who need to ship the same kind of overweight load frequently. Most States limit permit issuance to nondivisible loads. However, for economic reasons, some States allow overlimit divisible loads (e.g., grain, crops, forest products, fuel, concrete) to be moved on a multiple-trip permit basis under grandfather provisions previously discussed (Section 3.1.2).

Table 7 shows a compilation of overweight permits issued by State authorities in fiscal year 1983. Permits are categorized first by divisibility of load, then by single or multiple trip. The table shows that overweight permitting is extensive in the United States. Over 1.1 million permits were issued during the year. The great majority ( 86 percent) of permits were single trip, nondivisible load permits. Divisible load permits were not issued by 23 States, and 22 States did not issue any multiple trip permits.

\subsubsection{Permit Weight Limits}

State weight limits allowable under special permits vary considerably and are confusing because of differing terminology. Some States specify a maximum routine permit weight, others specify a maximum absolute weight, and some States do not specify a maximum permit weight but rely on either a bridge 
TABLE 7

STATE OVERWEIGHT PERMITS ISSUEO IN FISCAL YEAR 1983

\begin{tabular}{|c|c|c|c|c|}
\hline \multirow[b]{2}{*}{ STATE } & \multicolumn{2}{|c|}{$\begin{array}{l}\text { OVERWEIGHT } \\
\text { DIVISIBLE LOADS }\end{array}$} & \multicolumn{2}{|c|}{$\begin{array}{c}\text { OVERWEIGHT } \\
\text { NONDIVISIBLE LOADS }\end{array}$} \\
\hline & SINGLE TRIP & MULTIPLE TRIP & SINGLE TRIP & MULTIPLE TRIP \\
\hline ALABAMA & 0 & 0 & 6,274 & 1,153 \\
\hline ALASKA & 0 & 0 & 276 & 6 \\
\hline ARIZONA & 1,286 & 8 & 8,725 & 52 \\
\hline ARKANSAS & 0 & 0 & 22,009 & 0 \\
\hline CALIFORNIA & 0 & 0 & 45,135 & 3.650 \\
\hline COLORADO & 0 & 0 & 36,313 & 0 \\
\hline CONNECTICUT & (1) & (1) & 16,024 & 0 \\
\hline DELAWARE & 0 & 0 & 5,976 & 0 \\
\hline DIST OF COL & 0 & 646 & 566 & 191 \\
\hline FLORIDA & 0 & 1,256 & 24,598 & 7,280 \\
\hline GEORGIA & 0 & 0 & 13,934 & 1,630 \\
\hline HAWAII & 43 & 194 & 2,431 & 65 \\
\hline IDAHO & 0 & 4,866 & 5,676 & 324 \\
\hline ILLINOIS & 169 & 0 & 46,027 & 0 \\
\hline INDIANA & 0 & (2) & 2,446 & 0 \\
\hline IOWA & 0 & 0 & 10,264 & 0 \\
\hline KANSAS & 0 & 0 & 20,667 & 0 \\
\hline KENTUCKY & 0 & 382 & 30,778 & 285 \\
\hline LOUISIANA & 0 & 5 & 76,332 & 32 \\
\hline MAINE & 0 & 0 & 5,689 & 0 \\
\hline MARYLAND & 0 & 0 & 988 & 104 \\
\hline MASSACHUSETTS & 0 & 8,211 & 0 & 4,324 \\
\hline MICHIGAN & 61 & 657 & 205 & 8,136 \\
\hline MINNESOTA & 1,257 & 1,076 & 5,714 & 1,008 \\
\hline MISSISSIPPI & 0 & 0 & 14,441 & 0 \\
\hline MISSOURI & 0 & 0 & 10,788 & 121 \\
\hline MONTANA & 0 & 0 & 15,157 & 0 \\
\hline NEBRASKA & 3,296 & 0 & 4,548 & 0 \\
\hline NEVADA & 8 & 917 & 2,409 & 448 \\
\hline NEW HAMPSHIRE & 0 & 0 & 59 & 4 \\
\hline NEW JERSEY & 0 & 0 & 3,619 & 0 \\
\hline NEW MEXICO & 0 & 0 & 8,783 & 0 \\
\hline NEW YORK & (3) & (3) & (3) & (3) \\
\hline NORTH CAROLINA & 0 & 0 & 14,809 & 3,264 \\
\hline NORTH DAKOTA & 25,136 & 0 & 43,589 & 0 \\
\hline $\mathrm{OHIO}$ & 767 & 0 & 21,524 & 2 \\
\hline OKLAHOMA & 0 & 2,890 & 23,771 & 0 \\
\hline OREGON & 0 & 9,253 & 234 & 74 \\
\hline PENNSYLVANIA & 81 & 0 & 66,328 & 0 \\
\hline RHODE ISLAND & 0 & 2,118 & 854 & 4 \\
\hline SOUTH CAROLINA & 0 & 0 & 23,221 & 0 \\
\hline SOUTH DAKOTA & 17,517 & 0 & 2,971 & 36 \\
\hline TENNESSEE & 0 & 1,117 & 9,876 & 1,079 \\
\hline TEXAS & 0 & 0 & 202,601 & 0 \\
\hline UTAH & 38,672 & 1,781 & 6,706 & 46 \\
\hline VERMONT & 0 & 455 & 2,635 & 812 \\
\hline VIRGINIA & 0 & 5,579 & 1,141 & 205 \\
\hline WASHINGTON & 0 & 3,566 & 29,103 & 0 \\
\hline WEST VIRGINIA & 0 & 0 & 17,137 & 0 \\
\hline WISCONSIN & 0 & 397 & 24,545 & 1,526 \\
\hline WYOMING & 168 & 0 & 48,182 & 0 \\
\hline AMERICAN SAMOA & & & & \\
\hline GUAM & & & & \\
\hline PUERTO RICO & 0 & 0 & 0 & 5 \\
\hline VIRGIN ISLANDS & & & & \\
\hline TOTAL & 88,460 & 45,374 & 986,068 & 35,866 \\
\hline
\end{tabular}

Footnotes

(1) 78 total permits not stratified.

(2) 7476 Oversize/Overweight permits on Indiana Toll Road

(3) 172 mutiple trip permits, 788 single trip permits; not stratified as to Divisible or Nondivisible. 
formula or table, or conduct a case-by-case analysis of all permit applications. Adding to the confusion, the limit called "absolute" by one State may be the same as a "routine" limit identified by another State, since both States have essentially the same criteria for exceeding permit limits.

Regardless of what the limits are called, most States have adopted standard procedures to expedite the processing of permit applications for certain weights. The policies for allowing shipments to exceed these limits vary. The results of a survey conducted by the Transportation Research Board (TRB) are presented in Table 8.* It shows that at least 20 States will not allow higher weights except under emergency or very special circumstances. At least 32 States require extensive route surveys, approval from highway engineers, bridge engineers, or highway patrol officials, or require special studies.

Appendix A lists the maximum allowable weights authorized under permit as reported by either State weight officials, or by the Vehicle Sizes and Weights Manual compiled by J.J. Keller and Associates (1984), based on State permit procedure guides. For the analys is to be conducted in this report, however, the maximum allowable State permit weights are based on carrier experience. These weight limits are called "practical maximum" limits because they are based on past carrier experience as to what each State will normally allow without extensive justification and engineering analysis. Practical maximum GVWs are shown in the State weight table in Section 3.3 (Table 11) for vehicles of assumed axle configurations with a total of 6 to 9 axles. $\star \star$

* The criterion used to define "routine" permits by the TRB was that the requested weight was low enough not to require an extensive engineering analysis, bridge division check, or extensive route analysis.

**Tri-State Motor Transit Company (TSMT) has experience in obtaining overweight permits in virtually every state: it is familiar with the required axle spacing needed to maximize the number of States that will grant a permit for a given gross vehicle weight. The "practical maximum" permit limits used in this report are based on the TSMT axle configurations. The last column in Table 11 shows the "practical maximums" for a range of vehicle combinations with a low of six axles and a high of nine axles. 
TABLE 8

STATE POLICIES FOR SHIPMENTS EXCEEDING PERMIT MAXIMUM LIMITS

\begin{tabular}{|c|c|c|c|c|c|c|}
\hline State & $\begin{array}{c}\text { Emergency } \\
\text { or Very } \\
\text { Special } \\
\text { Circumstance } \\
\text { Only }\end{array}$ & $\begin{array}{c}\text { Route } \\
\text { Survey } \\
\text { Required }\end{array}$ & Approval From & $\begin{array}{c}\text { Special } \\
\text { Arrangement } \\
\text { Required }\end{array}$ & $\begin{array}{c}\text { Higher } \\
\text { Bond or } \\
\text { Insurance }\end{array}$ & Other \\
\hline Arizona & & & $\begin{array}{l}\text { Bridge Engineer \& } \\
\text { Highway Patrol }\end{array}$ & & & \\
\hline Arkansas & $x$ & & & & & $\begin{array}{l}\text { Axle limit not } \\
\text { exceeded }\end{array}$ \\
\hline California & & & & & & Formula \& table \\
\hline Colorado & & $\mathrm{x}$ & & & $x$ & \\
\hline Connecticut & & & & $x$ & & \\
\hline Delaware & & & Bridge Engineer & & & \\
\hline Florida & $x$ & & & & & $\begin{array}{l}\text { Essential to nat'I } \\
\text { defense }\end{array}$ \\
\hline Georgia & & & & $x$ & & \\
\hline Idaho & & $x$ & & $x$ & & \\
\hline Illinois & $x$ & & & $x$ & & \\
\hline Indiana & $x$ & & & $x$ & & \\
\hline lowa & & & & $x$ & & $\begin{array}{l}\text { Axle limits not } \\
\text { exceeded }\end{array}$ \\
\hline Kansas & $x$ & & & & $-110,000 \mathrm{lb}$ & \\
\hline Kentucky & & & & $x$ & & \\
\hline $\begin{array}{l}\text { Louisiana } \\
\text { Maine }\end{array}$ & $x$ & & Permit Engineer & $x$ & & \\
\hline Massachusetts & $x$ & $x$ & & & & \\
\hline Michigan & $x$ & & $\begin{array}{l}\text { Highway Engineer \& } \\
\text { Permit Section }\end{array}$ & & & \\
\hline Minnesota & $x$ & $x$ & & & & \\
\hline Mississippi & $x$ & & & $x$ & & \\
\hline Missouri & & & & $x$ & $x$ & \\
\hline Montana & & & $\begin{array}{l}\text { Gross Vehicle Weight } \\
\text { Division }\end{array}$ & & & \\
\hline Nebraska & $x$ & & & & & \\
\hline Nevada & & $x$ & & & & \\
\hline New Hampshire & & $x$ & & $x$ & & \\
\hline New Jersey & & & & & & Tire capacity \\
\hline New Mexico & & $x$ & & & & \\
\hline New York & & & & $x$ & & \\
\hline North Carolina & & & & $x$ & & \\
\hline North Dakota & $x$ & & & & & \\
\hline Ohio & & & & $x$ & & \\
\hline Oklahoma & $x$ & $x$ & & & & \\
\hline Oregon & & $x$ & Permit Supervisor & $x$ & $x$ & $\begin{array}{l}\text { Tire capacity } \\
\text { axle load }\end{array}$ \\
\hline Pennsylvania & $x$ & & Highway Engineer & & & \\
\hline Rhode Island & & $x$ & & $x$ & & \\
\hline South Carolina & $x$ & & & & & \\
\hline South Dakota & $x$ & $x$ & & & & \\
\hline Tennessee & & & & $x$ & & $\begin{array}{l}\text { Other transport } \\
\text { not available }\end{array}$ \\
\hline Texas & & & & & & $\begin{array}{l}\text { Other transport } \\
\text { not available }\end{array}$ \\
\hline Vermont & $x$ & $x$ & & $x$ & & $\begin{array}{l}\text { Other transport } \\
\text { not available }\end{array}$ \\
\hline Virginia & $x$ & & & & $x$ & \\
\hline Washington & $x$ & & & & & \\
\hline West Virginia & $x$ & & & & & \\
\hline Wisconsin & & $x$ & & & & \\
\hline Wyoming & & & $\begin{array}{l}\text { Office of Overweight } \\
\text { Load, Highway Patrol }\end{array}$ & & & \\
\hline
\end{tabular}

Source: Transportation Research Board, NCHRP Report 68. 


\subsubsection{Time Restrictions}

3.2.3.1 Time-of-Day and Day-of-Week. A11 but six States have some kind of time restriction on operating an overweight vehicle under permit. Table 9 shows the kinds of time restrictions which apply.

of the 43 States which restrict overweight travel on the weekend, 18 allow travel on Saturday during daylight hours. The number of holidays on which overweight travel is disallowed varies from 3 in Iowa to 12 in Connecticut. Most States prohibit overweight movements on New Year's Day, Memorial Day, Independence Day, Labor Day, Thanksgiving, and Christmas. Also, four States restrict overweight travel on the days before and after holidays, and eight restrict overweight travel on the afternoon of the day before holidays.

3.2.3.2 Seasonal and Weather. Most States have permit restrictions when the visibility is not good and prohibit movements on foggy days. Some also restrict various types of movements under snowy, icy, or rainy conditions. At least 30 states specify in their rules of procedure that carriers may not operate during various types of inclement weather.

TABLE 9. NUMBER OF STATES WITH TIME RESTRICTIONS IN OVERWEIGHT PERMITS

\begin{tabular}{lc}
\hline Type of Restriction & $\begin{array}{c}\text { Number of States Where Time } \\
\text { Restrictions to Overweight } \\
\text { Travel Pertain }\end{array}$ \\
\hline Rush Hour & 9 \\
Nights & 39 \\
Weekends & 43 \\
Holidays & 43 \\
\hline \hline
\end{tabular}

Source: Transportation Research Board, NCHRP Report 68. 
In some States heavy vehicle movements are subject to special seasonal considerations. These relate to the strength of the roadway during spring thaw and winter freeze. These restrictions are known as "frost laws." A total of 18 States have frost laws that could have an impact on routine overweight shipments. These laws vary considerably. North Dakota and Minnesota require that loads be reduced 25 percent on concrete and 35 percent on asphalt. Maine reserves the right to close certain highways from overweight travel completely from November to May. Vermont, Wisconsin, and Washington do not allow overweight permits during certain times. Maryland, Nevada, and other States re-route overweight or heavy trucks during the spring.

The tourist season is also considered. For example, New York State prohibits overweight movements on the days before and after holidays during summer only. Three States restrict movements for a whole day or half day on Fridays in summer. Utah procedures state that movements may be prohibited on days of expected high traffic volumes such as occur during hunting and fishing seasons.

\subsubsection{Route Restrictions}

Every State requires that routes be specified on the overweight permit. For routinely issued single-trip permits and for multiple-trip permits, most States have established a standard route network that automatically becomes an element of the permit. For weights exceeding certain specified permit limits, States require a detailed route survey and analysis. The States are particularly concerned with bridges, overpasses, congested areas, and conditions of roads. These factors could require the carrier to depart substantially from his desired route.

\subsubsection{Bridge Restrictions}

Genera11y, State permits do not authorize overweight vehicles to exceed posted bridge weight limits. This is reflected in the routes that are assigned overweight shipments. However, some State permits add further bridge restrictions. Massachusetts requires a bridge engineering analysis for loads 
greater than 130,000 pounds. Vermont and Mississippi place a 10 miles per hour bridge speed restriction for a 11 loads over 100,000 pounds, and 20 miles per hour if over 80,000 pounds.

\subsubsection{Other Permit Conditions}

\subsubsection{Accessories and Escorts. Many States require accessory} devices, or escort vehicles and personnel, to accompany oversize shipments. These can include flags, signs, vehicle markings, front- and rear-escort vehicles, and flagmen. However, few such accessory conditions apply to overweight shipments. Only four States indicate that any sort of flag or sign is required for overweight vehicles. Vehicle escorts for overweight movements are required or recommended by seven States and the District of Columbia. If escort vehicles are considered necessary, they usualiy require amber flashing beacons, flags, two-way radios, and warning signs.

\subsubsection{Road and Traffic Conditions. Some States require carriers} operating under an overweight permit to pull off the road under certain conditions. This is usualiy specified in State rules of procedure, rather than in the terms of the permit. Overweight carriers are required by 11 states to pull off the road whenever there is traffic congestion. These restrictions specifically include rush-hour embargos for certain heavily populated areas. In eight States, overweight carriers are required to pull off the road whenever road conditions are hazardous, and must notify state authorities.

3.2.6.3 Speed. Almost all States address allowable speeds in the overweight permit. All but 11 usually allow up to posted speed limits. In five States overweight trucks are restricted to $45 \mathrm{mph}$ and four other States restrict to $40 \mathrm{mph}$ or less, unless otherwise specified in the permit.

\subsubsection{Permit Applications}

3.2.7.1 Agencies. The State departments of highways or transportation have the responsibility to issue permits in 42 of 50 States. Within the departments, divisions involved may include maintenance, traffic, motor 
vehicles, safety, weights and enforcement, and special permit divisions. More than half the States have sections within the responsible divisions to handle permit applications. They work closely with bridge and other engineers in handling applications for shipments exceeding limits of routine permit issuance.

3.2.7.2 Procedures. The manner in which permits are issued varies substantia11y. Some States centralize all permit issuance, while others grant authority to district offices, ports of entry, weigh stations, and even trave 1 information bureaus. However, authority given local offices is usually limited. For example, they may be allowed to issue only single-trip permits, or movements within specified limits.

Permit application also varies depending on the State. In every State, an application can be made by mail or in person. However, the places where permits are picked up differ. In some cases, they may be obtained at ports of entry, district offices, or special agent offices at diverse locations. In other cases, they can only be picked up at, or mailed from, the central office. Truckers also use agents to obtain permits for them and receive the permits by mail or wire without ever directly contacting the State.

A11 but seven States will accept an application by telegram or other type of telecommunication, and most will also issue a permit the same way. Most States will accept an application by telephone, but only a few will issue permits in this way. Table 10 gives the general application and issuance procedures of the different States.

3.2.7.3 Fees. Fee structures vary considerably among the States for overweight permits. The following represent some approaches:

- Uniform fee: 10 States use this system on al1 permit moves, whether for a single- or multiple-trip permit.

- Permit duration: 14 States prescribe classes of fees for different permit durations.

- Number of shipments: Two States apply fees for all overweight movements based on the number of moves. 
TABLE 10. METHODS OF PERMIT APPLICATION AND ISSUANCE

Method

States Where Applicable

Application

In person

A11

Mail

A11

Telegram or other type of telecommunication

A11 except Delaware, Kansas, Mississippi, Missouri, Nebraska, Ohio, Wyoming

Telephone
A11 except Arkansas, California, Colorado, Connecticut, Delaware, District of Columbia, Maine, Minnesota, New Jersey, North Carolina, Ohio, Rhode Is land, Washington, West Virginia, Wiscons in

Issuance

In person

A11

MaiT

A11

Telegram or facsimile

Al1 except Delaware, Kansas, Mississippi, Ohio, Wyoming

Telephone

Arkansas, Louisiana, Mississippi, Utah

Source: Transportation Research Board, NCHRP 68.

- Per-mile-traveled: Some States charge on a per-mile basis with a minimum or maximum fee.

- Amount of overweight: 16 States peg their fees to the amount of overweight and 14 of these States also consider the travel mi leage.

The method of fee payment may also differ. Some States permit charge accounts, and at least one has prepaid permits for some types of movements. In other cases, payment must accompany the permit application.

\subsubsection{Financial Responsibility}

Most States specifically require that carriers show evidence of enough insurance to protect against any damage and liability claim likely to 
arise from an overweight movement. At least 27 states include such a provision in their rules of procedure. In 13 States a minimum level of financial protection is required that varies from $\$ 10,000 / \$ 100,000$ to $\$ 100,000 / \$ 300,000$ public liability and $\$ 10,000$ to $\$ 50,000$ property damage. These States require evidence of such insurance before issuance of permit. A surety bond or cash deposit to cover potential road or structure damage from the overweight load may be required in 20 States.

\subsection{STATE WEIGHT TABLE}

Table 11 shows the maximum weights allowed by the States on Interstate highways, noninterstate highways, and under special permit conditions for given vehicle configurations.

A word of caution when reviewing Table 11 is appropriate here. One of the few certainties in the world of vehicle weight control and regulation is that few agree on what the "correct" State legal and permit weight limits rea11y are. Because of the many State and Federal weight laws involved, and the confusion over legitimate grandfather rights and statutory exceptions, there is considerable disagreement. An FHWA attorney stated that he has never seen two lists of weight limits put out by different organizations which agree completely. The following table is based mostly on data of the American Trucking Associations, Inc., which is recommended by the FHWA source as "as good a source as any in this area."

Two other points about the table are in order. The permit weights which are listed are "maximum practical" weights for vehicle configurations described in Chapter 4. Higher or lower limits may apply in a given State for other configurations. Also, as previously mentioned, the use of the Bridge Formula B (or tables based on the formula called Table B), is not universal. Another formula used by many States is called Formula A (or Table A). This is shown in the Gross Weight Law column. Formula A differs from Formula B only in the constant term (see Table 3 of this report). The net effect of the difference is that Formula $A$ results in a decrease of 2,000 pounds allowable for corresponding axle groups. 
TABLE 11

STATE WEIGHT TABLE

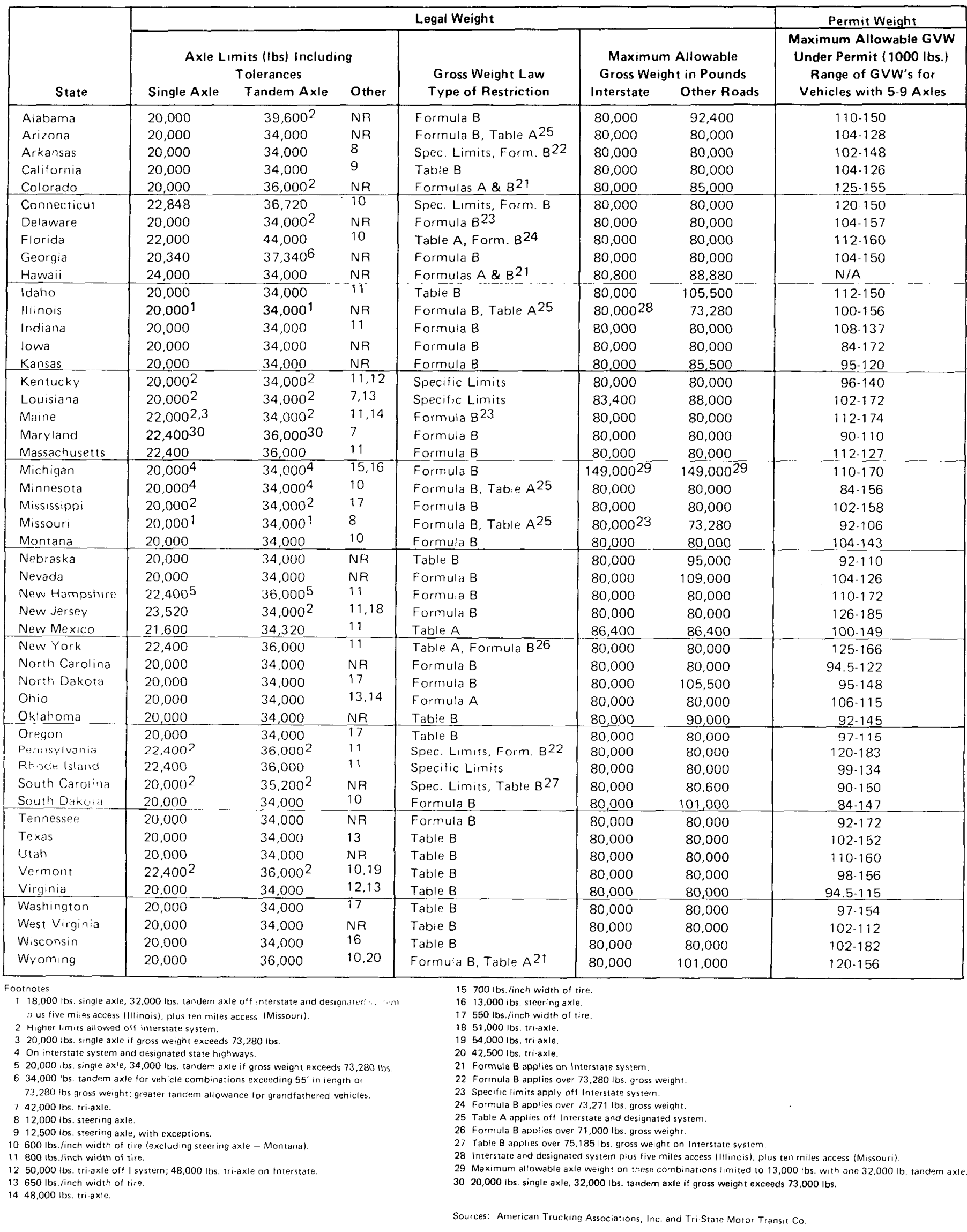




\subsection{NUCLEAR OVERWEIGHT SHIPMENTS}

The last two chapters provide the background and detail necessary to understand the Federal and State systems of vehicle size and weight control as well as the State weight limits and permit operations. This chapter considers the specific aspects of nuclear waste transportation and its relationship to the regulatory structure and political environment of vehicle weight control and permitting. First, it is necessary to consider what has been done in the past. The nuclear industry has faced many of the same problems now confronting DOE. One such problem is the relatively low productivity of highway casks. Industry and DOE experience in addressing this problem relative to highway weight control is reviewed below.

The second area to consider in this chapter is the actual operating experience with overweight shipments of nuclear waste and spent nuclear fuel. The operations of a large carrier and some recent shipping campaigns are reviewed. They provide some illustration of the current shipping environment. The last part of this chapter will consider representative cask/ vehicle designs for both a legal-weight truck (LWT) and an overweight truck (OWT) for the purpose of comparing relative impacts of the transportation necessary to support the repository program.

\subsection{PAST CONSIDERATIONS FOR DEVELOPING AN OVERWEIGHT TRUCK CASK}

Overweight truck shipments have long been considered as an option for transporting spent fuel from reactors to reprocessing facilities, storage facilities, or repositories. This is primarily out of necessity and cost. Physical constraints on cask design are imposed by the length of the fue 1 pins, gamma and neutron shielding, and features required for accident resistance to comply with U.S. Department of Transportation (DOT) and U.S. Nuclear Regulatory Commission (NRC) regulations. This has resulted in the production of legal-weight truck casks with a capacity of only one pressurized-water reactor and two boiling-water reactor fuel elements ( 1 PWR/2 BWR). These casks are very close to legal-weight limits when placed upon the transport. 
vehicle. The casks have a payload of less than 5 percent of total vehicle weight (compared to other general freight that is typically 65 to 70 percent of vehicle and container weight). Thus, the only option in the past to increase the cask payload, even by one unit, was to design a cask that exceeded legal-weight limits when empty. Utilities, especially those which operate reactors without rail access, have long been interested in improving the productivity of the truck cask.

This was well illustrated in 1970 when several companies planning to build reprocessing facilities in South Carolina arranged a meeting with State highway departments. This meeting was coordinated by the Southern Interstate Nuclear Board (now the Southern States Energy Board), specifically to discuss overweight shipments of spent fuel (Southern Interstate Nuclear Board, 1970). The State representatives were asked to consider repetitive overweight permits in the vicinity of 115,000 pounds, and shipments on nights and weekends.

Industry representatives were from utilities, carriers, reprocessors, and other fuel-cycle service companies. At issue, was the development of a transportation system to move spent fuel from the reactors in the south to the proposed reprocessing facilities in South Carolina. Cask designers were anxious at the time to get a firm commitment from the States on acceptable permit weights so that the largest possible cask could be designed beginning in the summer of 1970. Industry representatives strongly indicated that a highway cask with a payload of at least 2 PWR units was the minimum practical size from the standpoints of economics and the receiving facility physical Timitations.

Industry presented three alternative options to the States to address the transportation problems of reactors without rail access. First, an 80 to 100 ton rail cask was identified as an option. This, however, was not recommended by industry because the short haul from reactor to railhead would require extremely high axle weights. Second, a 40 to 70 ton rail cask was identified and recommended as a potential option. This would require a gross vehicle weight (GVW) of up to 240,000 pounds for the short haul between reactor and railhead. The last alternative, and the one of most interest, was a 30 to 40 ton truck cask to be used as a through-truck movement, requiring repetitive permits, in the vicinity of 115,000 pounds. Industry stated that 
this was in the vicinity of the average size OWT permit granted by the States for other shipments in the south.

The State representatives expressed a number of reservations with these alternatives. They included the following:

- Casks which contain more than one element would be considered a divisible load for which some States cannot legally issue OWT permits; States suggested that the industry design casks within legal limits if more than one element is to be involved.

- A gross vehicle weight (GVW) of 115,000 pounds would cause serious overstress to most State bridges off the Interstate system.

- Night and weekend moves would create safety hazards.

- Any exceptions granted to nuclear industry, however unique the problems are, would cause other industries to seek the same relief; some States expressed doubts that they could legally allow relief for one industry segment but not for others.

There were no agreements reached in the meeting between the nuclear industry and the State highway officials. Also, follow-up meetings between the two groups never resulted in any narrowing of differences, in part because of developments in the industry which delayed the immediate need for spent fuel casks to service reprocessing facilities.

The problems of developing overweight truck casks were addressed again in the late 1970 's when the DOE's Office of Waste Isolation (OWI) commissioned several studies of the capability of the nuclear transportation industry to support repository and/or reprocessing facilities.

The first study was conducted by the Nuclear Assurance Corporation (NAC) and a report was completed in 1977 which identified OWT shipments and highway conditions as two of the 14 key industry problems in nuclear waste transportation (Best et a1., 1977, pp. 117 and 125).

NAC identified the determination of load divisibility as the most critical issue facing OWT shipments:

A restriction exists for the issuance of OWT permits for divisible and separable loads. In the past this restriction has not been strictly enforced. It is clear, however, that such permit requests can be refused for cask shipments where the cask empty load is within the legal limit but the amount of waste loaded produces the overweight condition. Multi-element spent fuel shipping casks may be affected if the criteria is strictly interpreted and applied." (Best et a1., 1977, p. 127). 
Other problems involved with State permitting identified by NAC included: the length of time to process and issue permits, the lack of uniformity in State procedures, restrictions on travel times, frost laws, and extra costs associated with State permit procedures. NAC recommended that DOE/OWI establish programs to identify commonalities in State transport restrictions for OWT shipments, collect detailed information regarding road and highway conditions and restrictions, and resolve the interpretation and application of divisible load criteria.

The second study for OWI was conducted by Allied-General Nuclear Services (AGNS). AGNS was asked to report on the overall status of the transportation system in the United States for radioactive waste and to identify key elements for future program considerations. AGNS completed its comprehensive report in February 1978 (Anderson et a1., 1978). The report was intended to help DOE "develop a packaging and transportation system to support operation of a Federal repository beginning in 1985."

AGNS reviewed the status of the problems and capabilities associated with each mode of transport at the time. Truck size and weight limitations were included as key areas of concern for the highway mode. The report noted the relative economic advantage of OWT over LWT shipments, and the potential importance of OWT shipments since 35 percent of reactors lacked rail access. Further, AGNS did not believe utilities would be willing to pay the high cost of providing rail access to these reactors (from 2 to 40 miles). Consequentiy, the only alternatives for such reactors would be overweight truck or an intermodal arrangement requiring a heavy-haul to the nearest rail site.

AGNS reported that the OWT concept at the time typically consisted of a 105,000- to 125,000-pound GVW range that would accommodate 25- to 40-ton OWT casks. This would allow the payload to increase 200 to 300 percent. AGNS maintained that the unit cost of shipment is "clearly lower for this than either legal-weight truck or rail shipment."

DOE continued to have AGNS evaluate the commercial waste transportation system. AGNS produced a series of reports between 1978 and 1981 which were collectively titled Nuclear Transportation Studies Related to the Use of the Barnwel1 Nuclear Fuel Plant (see, e.g., Anderson, 1981). These reports compared the relative merits of various shipping options from reactors without rail access to the Barnwell facility. The options included legal-weight 
truck, overweight truck, and various intermodal arrangements involving both water and rail. The earlier reports in 1978 and 1979 indicated a substantial cost advantage for the OWT over both the LWT and rail modes. However, the political and administrative problems of obtaining permits and the time restrictions involved were seen as severe limitations. For long distance moves, AGNS stated that "... overweight truck shipments, which offer the greatest economic incentive could be 'mired-down' in conflicting regulations, permits, etc. and for this reason, overweight truck shipments are impractical and not to be counted on as a possible transportation alternative" (Anderson and Maier, 1979, p. 18).

In a 1981 report (Anderson, 1981, p. 11), AGNS took note of an important development that made the OWT option more attractive relative to the LWT. Increasing legal impediments and state involvement in all types of nuclear waste shipments were making it as difficult to ship an LWT cask as an OWT cask. AGNS concluded:

The issuance of shipping permits required for OWT shipment are not currently seen as a significant risk in the utilization of this type of equipment. The availability of equipment in the U.S. can be supplemented by casks currently in Europe (i.e., the TN-8, TN-9, and possibly the Castor casks). Truck weight limitations can be surmounted by the use of intermodal alternatives.

\subsection{RECENT OWT SHIPPING EXPERIENCE}

Despite the problems associated with State permitting, overweight truck shipments continue to be numerous and routine throughout the United States. This is true to some extent for nuclear waste shipments also. The recent operational experience of a large carrier and some recent nuclear waste shipping campaigns illustrate this.

\subsubsection{Carrier Permitting Experience}

Tri-State Motor Transit Company (TSMT) is one of the largest highway carriers of spent nuclear fuel and among the largest in specializing in overweight and overdimensional shipments. TSMT has many years of experience in 
dealing with State overweight permit procedures and has well-established internal procedures to accommodate the complexity of dealing with 48 different sets of requirements. Consequent1y, TSMT offers a good case study of representative carrier operations involving overweight shipments and State permitting procedures.

TSMT handles from 700 to 1,000 oversize and overweight shipments per month. This has included several recent shipments which are well beyond the typical OWT State allowances. For example, a heat exchanger was moved from Texas to Louisiana with a GVW of 210,000 pounds. Another shipment of 160,000 pounds was moved from New York State to Seattle, Washington.

TSMT made over 200 overweight nuclear shipments over a 1-year review period (October 1983-September 1984), an average of 17 per month. The majority of shipments were casks containing low-level waste, spent nuclear fue1, or just empty casks. The nuclear OWT shipments have ranged between 80,000 and 110,000 pounds gross vehicle weight. Over 750 overweight State permits were obtained to make the 200-plus shipments, an average of about 3.7 per OWT shipment and 63 permits per month. Based upon TSMT's experience during the 1-year review period, State overweight permitting for nuclear shipments is relatively routine for both the carrier and the States.

TSMT has prepared internal guidelines on maximum weights and axle configurations that are allowed under permits issued by various States. The graph shown in Figure 1 is based upon these TSMT guidelines. The axle configurations shown along the horizontal axis are based upon TSMT equipment specifications designed to maximize allowable permit weights in as many States as possible.* For example, the 4-3 configuration for 7 axles involves the following axle spacing: 11 feet between the steering axle and the first axle of the tridem drive axle; 4 feet 1 inch between each of the tridem axles; and 25 to 32 feet between the last axle of the tridem drive axle and the first axle of the tridem trailer axle. TSMT axle spacing is believed to be typical of industry practice.

*This is based on the same TSMT data used to identify the range of practical maximum permit limits in Table 11 . 
FIGURE 1

Practical Maximum GVW Permit Limits Allowed

By States For Various Axle Configurations

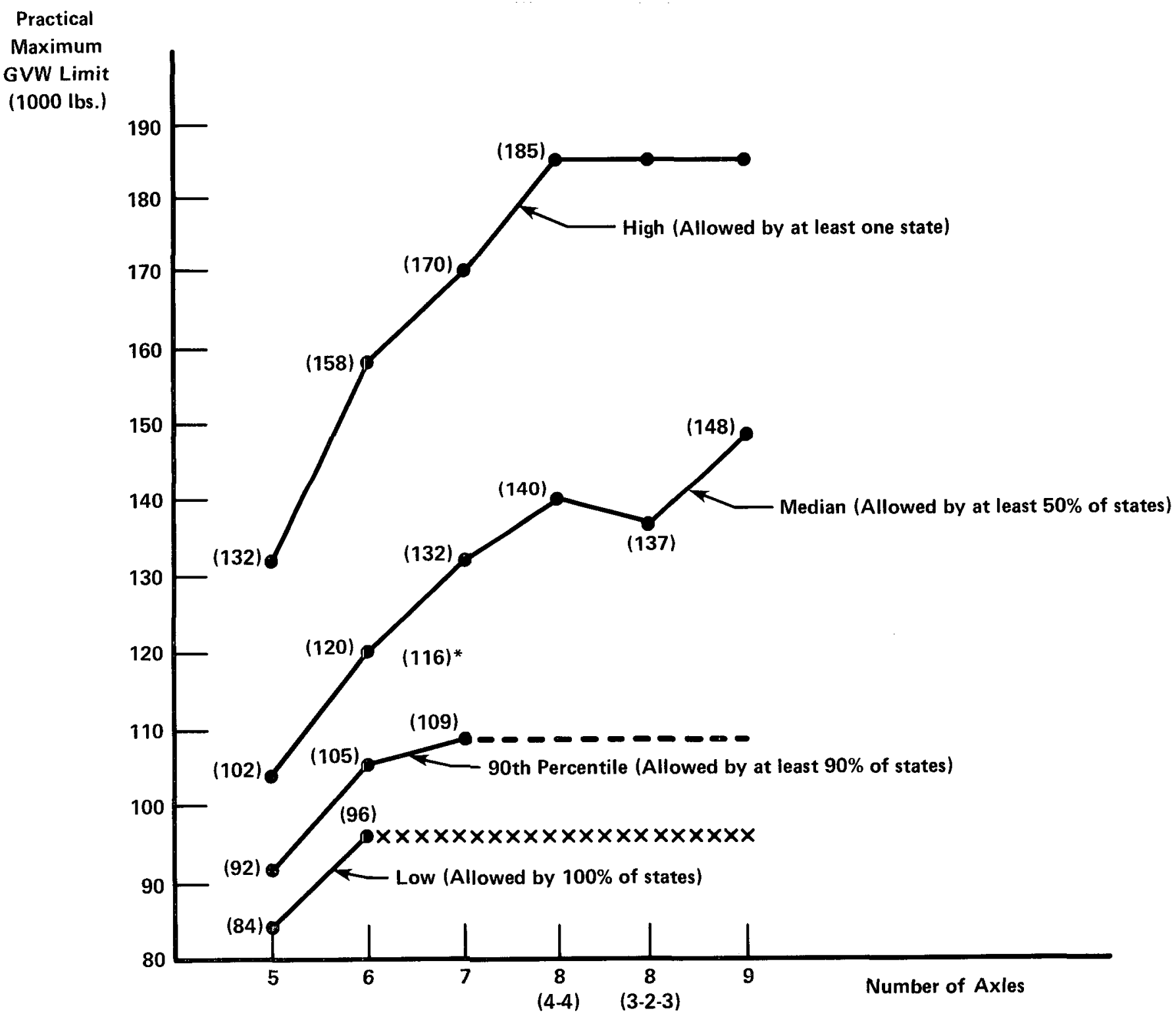

$x \times \times \times \times$ At least 3 states do not allow more than 6 axles or do not authorize additional weight for more than 6 axles.

At least 8 states do not allow more than 7 axles or do not authorize additional weight for more than 7 axles.

*Representative cask/vehicle design (OWT 2 ).

Source: Tri-State Motor Transit Co. and Battelle analysis. 
The weight limits shown along the vertical axis in Figure 1 are called "practical maximum" limits to distinguish them from "routine" limits or "absolute" limits. They are called practical because they are based on industry experience of what is allowed in most States without great difficulty. Higher limits are possible, but only under unusual or more difficult circumstances.

Figure 1 illustrates the great variation among State maximum permit limits depending upon axle configurations. For example, the range for maximum permit weights allowed for the TSMT 5-axle configuration is from a low of 84,000 pounds to a high of 132,000 pounds, with a median of 102,000 pounds. The range increases to 96,000 pounds (low) to 158,000 pounds (high) for 6-axle configurations. This range continues to increase as more axles are added to the vehicle/trailer up to a high of 185,000 pounds for 8 or more axles. However, after 6 axles, some States do not allow additional weight (and in some cases do not allow additional axles). Figure 1 also shows that 90 percent of the States would allow permits for a 7-axle GVW up to and including 109,000 pounds. The 1 ine representing the 90 th percentile would then flatten at a maximum of 109,000 pounds since at least eight States do not allow more than 7 axles, or do not allow additional weight for more than 7 axles.

\subsubsection{Recent Nuclear OWT Campaigns}

The following campaigns are presented to demonstrate that overweight shipments of spent nuclear fuel are feasible using existing equipment (TN-8 and TN-9) and under existing State limits and permit regulations. The campaigns involve gross vehicle weights from just over the 80,000 -pound legal limit up to approximately 111,000 pounds. They include short moves (531 miles and 4 States) and cross-country moves (2,620 miles and 10 States). A brief summary of each OWT campaign is provided to illustrate the features of overweight shipping operations.

\subsubsection{West Valley, NY, to Dresden, IL. Commonwealth Edison of} Illinois (CECO) was ordered by a Federal District Court in 1983 to take back 206 spent fuel assemblies that had previously been shipped for reprocessing to West Valley, New York. CECO used its TN-9 overweight cask for the 615-mile 
one-way trip between West Valley and its reactor at Dresden, I1linois. The TN-9 cask has a payload of 7 BWR assemblies, thus requiring a total of 30 loaded shipments and 30 return movements of the empty cask. Although the shipment involved only five States, 10 overweight permits were required (in addition to numerous other reports and notifications unrelated to weight). Table 12 illustrates the type and nature of the permits. Very little trouble was reported in the process of obtaining these permits.

The vehicle configuration used to transport the TN-9 consisted of a 4-3 arrangement ( 4 axies on the tractor and three on the trailer). * The tractor axles consisted of a steering axle and a tridem, or 3-axle group. The trailer axle was also a tridem. The breakdown of axle weights, as measured at an Illinois truckstop on one of the loaded shipments, was 10,100 pounds on the steering axle, 50,620 pounds on the drive tridem axle, and 50,500 pounds on the trailer tridem axle. Total GVW was 111,220 pounds. Each shipment was completed over a two-day period. Average driving time to cover the 615 miles was 15.6 hours for an average driving speed of 39.5 miles per hour.

According to Transnuclear, the overweight nature of these shipments was completely overshadowed by the fact that spent nuclear fuel was the cargo. As an example, special agreements were negotiated between the utility and the State of Ohio which involved provisions for State prenotification, escort vehicles, turnpike authority prenotification, travel restrictions, route surveys, and training of local emergency responders along the route. These provisions had nothing to do with the overweight nature of the shipments.

\subsubsection{West Valley, NY, to Oyster Creek, NJ. General Public} Utilities (GPU) was also required to accept 224 BWR assemblies from West Valley, New York, under the same court order identified above. Once again, TN-9 casks were used to move the assemblies the 531-mile one-way trip between West Valley and GPU's Oyster Creek reactor in New Jersey.

*Information on both West Valley campaigns (to Dresden, IL and to Oyster (reek, NJ) was supplied by Transnuclear, Inc. 
TABLE 12. OVERWEIGHT PERMITS REQUIRED FOR WEST VALLEY-DRESDEN CAMPAIGN

\begin{tabular}{|c|c|c|c|}
\hline Permit & $\begin{array}{l}\text { Number of Days } \\
\text { to Obtain }\end{array}$ & $\begin{array}{l}\text { Number of Days } \\
\text { Permit Valid }\end{array}$ & Notes \\
\hline NY State & $1-2$ & 5 & $\begin{array}{l}\text { Certificate number given } \\
\text { by New York DOT required }\end{array}$ \\
\hline NY Thruway & $1-2$ & & $\begin{array}{l}\text { Driver required to show } \\
\text { certificate to toll booth, } \\
\text { permit granted there }\end{array}$ \\
\hline PA State & 2 & 7 & $\begin{array}{l}\text { Permit must be requested no } \\
\text { later than } 48 \text { hours prior } \\
\text { to shipment }\end{array}$ \\
\hline $\mathrm{OH}$ State & $1-2$ & 5 & -- \\
\hline $\mathrm{OH}$ Turnpike & -- & Campaign & $\begin{array}{l}\text { OH permits not normally } \\
\text { issued by Turnpike. Trave } 1 \\
\text { was permitted due to nature } \\
\text { of the shipment by special } \\
\text { agreement betwen CECO and } \\
\text { the Ohio Turnpike Authority }\end{array}$ \\
\hline IN State & $1-2$ & 7 & -- \\
\hline IN Toll Road & $3-5$ & 7 & $\begin{array}{l}\text { Facsimile not acceptable, } \\
\text { original permit had to be } \\
\text { mailed to the trucker }\end{array}$ \\
\hline IL State & $1-2$ & 3 & -- \\
\hline IL Thruway & 1 & 1 & $\begin{array}{l}\text { Driver picked up permit at } \\
\text { entrance to the Thruway }\end{array}$ \\
\hline $\begin{array}{l}\text { IL-Wi11 County } \\
\text { Roads }\end{array}$ & - & 1 Year & $\begin{array}{l}\text { Blanket permit issued for } \\
1 \text { year period }\end{array}$ \\
\hline
\end{tabular}

Source: Contributed by Transnuclear, Inc. 
Although a different carrier was involved, the vehicle axle configuration was similar to that in the Dresden campaign. This consisted of a seven-axle tractor-trailer combination with four axles on the tractor and three axles on the trailer. Axle weights were approximately 11,900 pounds on the steering axle, 46,700 pounds on the drive tridem axie, and 52,140 pounds on the trailer tridem axle for a total GVW of 110,740 pounds.

Driving time varied from 14.5 hours to 16 hours over a period of two days for the loaded cask. Travel was restricted at night, but weekend travel was allowed, according to Transnuclear. Average driving speed was 33.5 miles per hour for the loaded cask. The empty cask also required two days for the return trip. Total shipment time for the round-trip, including night-time shutdown due to permit restrictions, averaged about 60.5 hours for an overa11 average speed of 17.5 miles per hour.

Single-trip permits were required for each shipment from New York, Pennsylvania, and New Jersey. The only problems reported by the carrier involved scheduling to account for travel restrictions at night. It is interesting to note that the State of New York allowed Sunday travel for this campaign contrary to its usual OWT policy.

\subsubsection{Canoga Park, CA, to Savannah River, SC. In 1979, spent} nuclear fuel was transported cross-country from Canoga Park, Cal ifornia, to the Savannah River, South Carolina, facility using the Hallam cask.* The loaded cask weight was 79,000 pounds, which would be similar to the weight of a future overweight cask containing 4 PWR fuel elements. The gross vehicle weight was 103,880 pounds distributed over 7 axles. Axle weights were 9,950 pounds on the steering axle, 46,010 pounds on the drive tridem axle, and 47,920 pounds on the trailer tridem axle.

The one-way shipment distance of approximately 2,500 miles was covered in 3 days. This was possible because only 2 of the 11 States restricted movement at night for this campaign. Consequently, the carrier provided continuous, 24-hour service using two drivers. Average campaign driving speed

\footnotetext{
*Information on the Canoga Park, CA, and Peach Bottom, PA, campaigns was supplied by TSMT.
} 
was 35 miles per hour. The Hallam cask has also been used for a number of overweight shipments in the opposite direction, from Savannah River to Canoga Park.

4.2.2.4 Peach Bottom, PA, to Idaho Falls, ID. Another series of overweight truck shipments of spent nuclear fuel occurred in 1974 from the Peach Bottom, Pennsylvania, reactor to Idaho Falls, Idaho. The cask was owned by the utility and weighed 57,000 pounds when fully loaded. For this move, the carrier used a heavy trailer, which has since become obsolete. Thus, the total GVW was 106,150 pounds on a 7-axle single-tridem-tridem arrangement. Axle weights were 11,050 pounds on the steering axle, 47,700 pounds on the drive axle, and 47,400 pounds on the trailer axle. The shipment distance was 2,350 miles, which was covered by the carrier in an average of 4 days, using two drivers. This movement was subject to nighttime travel restrictions, which reduced overal1 speed to 24 miles per hour.

\subsection{REPRESENTATIVE CASK/VEHICLE DESIGNS}

The purpose of this section is to consider a representative future overweight truck cask and vehicle configuration for comparative analysis. First, the representative cask/vehicle design is discussed in terms of State permit limits. Second, the representative design is compared with representative legal-weight and current overweight cask/vehicle designs in terms of transport cost, exposure, and highway damage.

There are a number of potential overweight cask designs that could be considered for this study. However, it is necessary to select one as "representative" of the future design. The design selected for this analysis is the 40-ton spent fuel cask concept presented in Appendix C. Of primary importance to this study is the weight and payload of the cask. It weighs from 67,000 to 67,500 pounds empty. Because the spent fuel to be shipped for the repository program will be at least 5 years old, this size cask is designed for 4 PWR spent fuel assemblies or 10 BWR spent fuel assemblies. Its maximum loaded weight is designed to be 80,000 pounds.

The acceptability of the 40-ton cask to state permitting authorities depends greatly on the vehicle and trailer configuration. As previously 
discussed, State rules and procedures on single, tandem, tridem, and gross vehicle permittable weights are very different, and it is impossible to determine the acceptability of an item unless exact axle weights and spacing are given. The vehicle/trailer design shown in Appendix $C$ is considered "representative" of future designs that would accommodate the 40-ton cask.* It consists of 7 axles and is a basic 4-3 configuration, which includes 4 axles attached to the vehicle and 3 axles attached to the trailer. The axle spacing is designed to maximize the weight allowable under as many State permit limits as possible based upon TSMT data. When the 40-ton cask is placed on the trailer, axle weights include 11,000 pounds on the steering axle, 51,000 pounds on the tridem drive axle, and 54,000 pounds on the tridem trailer axle. Gross vehicle weight is 116,000 pounds.

\subsubsection{State Permitting for Representative OWT Design}

Figure 1 shows the "practical maximum" gross vehicle weight limits authorized by States under permit depending upon TSMT axle configurations and axie weights. The 7-axle OWT cask/vehicle design described above is represented by an asterisk in Figure 1. Based upon TSMT data, it appears that 38 of the 48 contiguous States could conceivably grant an overweight permit for a GVW of 116,000 pounds and axle weights of 11,000, 51,000, and 54,000 pounds. In most cases, 10 States would not authorize a GVW up to that 1 imit, and 7 of these 10 States would not authorize one or both of the tridem axle weights. The 10 States not likely to grant permits without a more exhaustive justification, according to TSMT, include Ohio, West Virginia, Virginia, Indiana, Missouri, Nebraska, Arizona, California, Nevada, and Oregon.

It is important to emphasize that these findings are tentative. They are based on typical industry equipment specifications and TSMT experience with State permitting. A more carefully evaluated OWT cask/vehicle design could yield a higher or lower GVW and axle weights that could substantially affect its ability to qualify for permits. For example, new trailer

\footnotetext{
*The representative trailer design for a future OWT cask was drawn by the Overdimensional Department at TSMT.
} 
designs involving lower weights and/or more creative axle-spacing capability could enhance the ability to qualify for permits. However, Figure 1 does provide some indication of the range of GVWs and axle weights for a representative OWT cask/vehicle design that would satisfy the greatest number of State permitting authorities.

\subsubsection{Comparison of Impacts}

It is readily apparent that, compared with legal-weight truck casks, overweight truck casks with a higher payload will reduce the total number of shipments required to serve a Federal repository or a monitored retrievable storage (MRS) facility. This, of course, will directly affect the transport cost and risk associated with the repository program. This section compares four different cask/vehicle systems in terms of impacts created by transporting spent nuclear fuel to repositories. Three impacts are analyzed: transport cost, occupational exposure time, and highway damage.

The four cask/vehicle systems include current LWT and OWT systems and representative future LWT and OWT systems as shown in Table 13. The current legal-weight cask (LWT 1 ) is the NLI-1/2 cask with a payload of 1 PWR or 2 BWR fuel elements. The cask weighs 45,000 pounds when loaded; the gross vehicle weight of 74,500 pounds is distributed over five axles. The future legal-weight cask ( $L W_{2}$ ) is represented by the 25-ton cask concept shown in Appendix C. It contains 2 PWR or 5 BWR fue 1 assemblies and weighs 50,500 pounds when loaded. The GVW is 79,000 pounds, distributed over five axles.

The current overweight cask (OWT 1 ) is the TN-8 or TN-9 cask, with payloads of 3 PWR and 7 BWR fuel assemblies, respectively. The cask weight is assumed to be 78,600 pounds (based upon recent West Valley shipments) with a gross vehicle weight of 111,000 pounds distributed over seven axles. Finally, the future overweight cask (OWT2) is represented by the 40-ton cask design described in the last section.

To simplify comparisons between legal-weight and overweight truck casks, it is assumed that the repository program will be served by 100 percent truck, which is consistent with the assumptions used in the generic transportation appendix for the draft environmental assessments (DOE, 1984). An average round trip distance of 2,720 miles from reactors to a repository 
TABLE 13. CASK/VEHICLE CONFIGURATIONS FOR COMPARISON

\begin{tabular}{|c|c|c|c|c|c|}
\hline & Type Cask & Payload & $\begin{array}{l}\text { Loaded Cask } \\
\text { Weight } \\
\text { (pounds) }\end{array}$ & $\begin{array}{c}\text { GVW } \\
\text { (pounds) }\end{array}$ & $\begin{array}{c}\text { Axle } \\
\text { Conf iguration } \\
\text { and Weights }\end{array}$ \\
\hline $\mathrm{LWT}_{1}$ & $\begin{array}{l}\text { Current Legal } \\
\text { Weight }(N L I-1 / 2)\end{array}$ & $\begin{array}{ll}1 & \text { PWR/ } \\
2 & \text { BWR }\end{array}$ & 45,000 & 74,500 & $\begin{array}{c}(3-2) \\
10-32 \cdot 5-32\end{array}$ \\
\hline$L_{W} T_{2}$ & $\begin{array}{l}\text { Future Legal } \\
\text { Weight ( } 25 \text { Ton) }\end{array}$ & $\begin{array}{ll}2 & \text { PWR/ } \\
5 & B W R\end{array}$ & 50,500 & 79,000 & $\begin{array}{c}(3-2) \\
11-34-34\end{array}$ \\
\hline OWT $_{1}$ & $\begin{array}{l}\text { Current Over- } \\
\text { weight (TN-8/9) }\end{array}$ & $\begin{array}{ll}3 & \text { PWR/ } \\
7 & \text { BWR }\end{array}$ & 78,600 & 111,000 & $\begin{array}{c}(4-3) \\
12-47-52\end{array}$ \\
\hline $\mathrm{OWT}_{2}$ & $\begin{array}{l}\text { Future Over- } \\
\text { weight ( } 40 \text { Ton) }\end{array}$ & $\begin{aligned} 4 & \text { PWR/ } \\
10 & \text { BWR }\end{aligned}$ & 80,000 & 116,000 & $\begin{array}{c}(4-3) \\
11-51-54\end{array}$ \\
\hline
\end{tabular}

Source: Battelle analysis.

location is used. This is considered representative of the myriad of origindestination pairs that could evolve from the repository program. The use of an intermediate MRS facility for fuel consolidation and repackaging is currently under evaluation by DOE and is not considered for the present study. However, the effect of the MRS facility should not change the relative impacts, computed below, of the four cask/vehicle systems for the 100 percent truck scenario.

To facilitate comparison of impacts among the four casks, a Shipment Index is used. It is derived from the differential in total repository shipments that would be required for each given payload. The base is the number of truck shipments required for current legal-weight casks (LWT1) with a payload of 1 PWR/2 BWR. The shipment index for the other three casks is the fraction of PWR truck shipments required compared to LWT 1 . Future legal weight casks (LWT2) with a 2 PWR/5 BWR payload would necessitate one-half the shipments required by LWT 1 and therefore have a shipment index of 0.5 . Likewise, OWT 1 with a 3 PWR/7 BWR payload and OWT 2 with a 4 PWR/10 BWR payload 
have shipment indices of 0.33 and 0.25 , respectively.* The cost, exposure, and highway damage results presented below are computed on a per shipment basis. Each result is then multiplied by the shipment index to reflect the differential in shipments that would be required for the repository program. Thus, the final figures are relative impacts for comparison among alternatives only.

4.3.2.1 Cost. Total transport costs consist of shipping charges, capital costs and maintenance costs. Shipping charges are based upon the weight and distance of the shipment. The estimates in Table 14 (presented at the end of Chapter 4) are based upon quotations provided by TSMT based upon the tariff for spent nuclear fuel (Gillogly, 1984). The charges for a loaded legal-weight cask are $\$ 6.93$ per hundred weight (CWT) plus 92 cents per mile security charge. The empty weight charge is $\$ 5.79$ per CWT and 15 cents per mile security charge. Total shipping charges for the two legal-weight truck casks identified above for a 2,720-mile movement would be approximately $\$ 7,100\left(\mathrm{LWT}_{1}\right)$ and $\$ 7,800\left(\mathrm{LWT}_{2}\right)$.

Overweight shipments are charged at a rate of 112 percent of lega 1weight shipments. This reflects a special-equipment surcharge since a fouraxle tractor is required. Thus, the loaded weight charge would be $\$ 7.76$ per CWT. In addition, the security cost is $\$ 1$ per mile and the charge for various State permits is approximately 55 cents per mile based upon TSMT experience. The empty OWT cask weight charge is $\$ 6.48$ per CWT. Thus, total shipping charges for the 2,720-mile shipment for the OWT 1 and OWT 2 casks are $\$ 13,900$ and $\$ 14,100$, respectively, as shown in Table 14 .

TSMT reported that actual shipping charges could be much higher than these figures indicate since equipment deadhead and detention charges have not been included. TSMT estimates that detention charges (time at loading/unloading site) average 20 percent of total freight charges for LWT casks and have

\footnotetext{
*The shipment index presented here is actually based on the differential in PWR shipments only in order to simplify comparisons and would be slightly different if BWR shipments were included. However, the index is accurate when comparing LWT2 $(2 / 5)$ and OWT2 $(4 / 10)$ which is the real purpose of this section.
} 
been as much as 150 percent of freight charges for some of the early West Valley OWT shipments.

The capital cost component of total transport cost is estimated by assuming that casks are leased by DOE. DOE has not made a decision yet as to whether it will own spent fuel casks to be developed for the repository program or if it will lease the casks from a supplier. Since the costs of future casks are highly uncertain, it was decided to use lease rates based upon past experience as the measure of capital cost for this analysis. A lease rate of $\$ 1,500$ per day is assumed for legal-weight casks based upon estimates used in a 1981 study by AGNS on spent fuel shipping costs (Anderson, 1981 , p. 6). A lease rate of $\$ 2,000$ per day is assumed for the overweight casks. The capital cost per shipment is dependent upon total trip time.

Total trip time is composed of transit time and facility turnaround time. To calculate transit time, an average driving speed of $35 \mathrm{mph}$ was assumed based upon the previous study and recent shipping experience. This was assumed to be the case for both LWT and OWT options. However, the OWT option was limited to an average of 12 hours of operation per day because of State permit restrictions that typically do not allow nighttime travel. Thus, for the current scenario, the total transit time for LWT is estimated to be 78 hours or 3.25 days $(2,720$ miles divided by $35 \mathrm{mph})$, which is the same as actual driving time since continuous, 2-driver operation is expected. Total transit time for OWT is estimated to be 126 hours or 5.25 days, which allows for two 12-hour shutdowns at night on both the loaded move and the return trip. It should be noted that comparison of transit time is highly dependent upon the distance of the move. For shipments of less than 420 miles, transit time would be the same for both LWT and OWT (assuming $35 \mathrm{mph}$ average speed and 12 hours of daylight) since there would be no nighttime shutdown. For multi-day trips covering greater distances, the difference between LWT and OWT transit times becomes even greater. Also, many States require shutdown for at least 36 hours if an overweight shipment extends over the weekend. The present analysis does not account for potential weekend travel restrictions. Facility turnaround time is based upon a previous study by AGNS (Anderson, 1978, pp. 10-11) which estimated elapsed time for unloading LWT and OWT casks to be 12.75 hours and 15.75 hours, respectively. These figures are doubled to estimate total loading and unloading time at facilities to be 
approximately 26 hours for LWT and 32 hours for OWT. Thus, total trip time, including both transit and facility turnaround time, is estimated to be 104 hours ( 4.3 days) for LWT and 158 hours (6.6 days) for OWT.

The total capital cost per shipment is then found by multiplying the daily lease rate by the total trip time. Capital cost for LWT is, therefore, $\$ 6,450$ per shipment and for OWT is $\$ 13,200$ per shipment as shown in Table 14 .

The final transport cost component is maintenance cost. Maintenance charges are based upon the first repository cost/risk analysis completed by Sandia National Laboratories, which estimated maintenance cost of spent fue 1 casks at $\$ 75,000$ per cask per year for current generation (i.e., legal-weight) casks (Neuhauser et a1., 1984, p. 17). A maintenance charge of $\$ 100,000$ per cask per year is used for OWT casks. These charges are divided by the number of shipments per cask per year ( 300 shipping days divided by the round-trip time) to arrive at a maintenance charge per shipment.

Total transport costs per shipment are combined as shown in Table 14. These costs are multiplied by the appropriate shipment index to arrive at relative costs associated with each cask/vehicle system. As shown, the low cost alternative using the assumptions in this analysis is OWT $_{2}$ (future overweight). This is followed by the LWT2 (future legal-weight) alternative.

These results are considered tentative because of the static analysis used to estimate costs and the many assumptions that are required. Although it is believed that reasonable assumptions are used throughout the analysis, the results could change if key assumptions are varied or if better or more recent data become available.

\subsubsection{Occupational Exposure Time. Another measure of relative} impacts among the four alternatives is exposure time to the drivers and faci1ity personnel (i.e., the occupational exposure). This may be considered representative of the relative risk associated with the alternatives. In general, the total radiological risk can be expected to vary in a similar manner as occupational exposure.

Occupational exposure depends upon total transit time and facility turnaround time. These are computed for each alternative using the same assumptions as before. As shown in Table 14, the total driving time for the 
loaded cask is 39 hours $(1,360$ one-way mileage divided by an average speed of $35 \mathrm{mph}$ ) for both LWT and OWT. Assuming a crew of 2 drivers, total driver exposure time is 78 man-hours for both the LWT and the OWT.

Facility turnaround times are based upon AGNS experience with unloading LWT and OWT casks (Anderson, 1978, pp. 10-11). AGNS found that a crew of 3 to 4 personnel was required for both types of casks and that it took 42.4 man-hours to unload the LWT and 58.9 hours to unload the OWT. These figures are doubled to estimate total loading and unloading exposure time. Thus, total exposure time including transit and facility turnaround for each shipment is estimated to be 162.8 man-hours for the LWT and 195.8 man-hours for the OWT.

After applying the shipment index to reflect the differential in the number of shipments required for each design, Table 14 shows that the future overweight cask (OWT2) has the lowest estimated exposure time and is about 60 percent of the estimated exposure time of the future legal-weight cask alternative $\left(L W T_{2}\right)$.

\subsubsection{Hiqhway Damage. A commonly accepted unit of measure for} comparing the relative pavement damage caused by various vehicle weight classes is the equivalent standard axle load (ESAL). ESALs are based upon the relationship between pavement thickness, the loss in pavement serviceability over a period of time and the frequency and magnitude of total axle loadings over a pavement during the same time period. As discussed previously, this relationship is mathematically derived from data collected during the American Association of State Highway and Transportation Officials (AASHTO) Road Tests in the 1950s and 1960s. The Federal Highway Administration (FHWA) has relied upon ESAL values for the purpose of allocating the cost of new and rehabilitated highways among various vehicular weight categories. In two of its most recent studies, the Final Report on Federal Highway Cost Allocation Study (DOT, 1982) and Alternatives to Tax on Use of Heavy Trucks (DOT, 1984a), FHWA employed ESAL values to apportion the cost of new pavement construction on the Federal-aid highway system to 38 vehicular classes. Further details on the derivation and computation of ESAL values are presented in Appendix $D$.

An ESAL is a standardization of the amount of highway damage caused by various axle weights. A procedure was developed by AASHTO to convert 
different vehicular axle-weight configurations into a single, standard "axle load equivalent." The standard selected was the 18,000-pound single axle. Thus, an ESAL represents the loss in serviceability of a highway over time due to repeated applications of various axle loads converted to 18,000-pound axleload equivalents. Pavement damage caused by a given vehicle is represented by the sum of the ESAL factors for a 11 its axles. Because the tandem axle distributes weight differently, separate procedures are used to compute ESALs for single and tandem axles. In addition, new AASHTO procedures have been recently adopted for tridem axles (AASHTO, 1985).

Table 14 shows the ESAL values for flexible and rigid pavements for each of the vehicle/axle configurations. Computations of ESALs are contained in Appendix D. According to an FHWA source, the Interstate system in the United States is approximately 57 percent rigid pavement and 43 percent flexible pavement. This ratio was used to compute composite ESAL values for each vehicle.

The current legal-weight cask/vehicle design consisted of a single axle weight of 10,000 pounds and two tandem axle weights of 32,500 and 32,000 pounds, respectively. The total composite ESAL value for LWT $_{1}$ is 2.64. LWT2 requires only slightly higher axle weights to accommodate twice the payload of LWT 1 , because of lower cask weight to accommodate the older fuel to be shipped in the future. Its axle weights of $11,000,34,000$, and 34,000 pounds result in a total composite ESAL value of 3.28 .

The overweight cask/vehicle designs necessitate the use of tridem axles. OWT 1 has two tridem axles of 47,000 and 52,000 pounds each. The total composite ESAL for OWT 1 would be 4.51. Similarly, the composite ESAL for $\mathrm{OWT}_{2}$, which has tridem axles of 51,000 and 54,000 pounds, would be 5.53.

In order to compare relative highway damage for the entire repository program, the single vehicle ESAL values computed above need to be adjusted to account for the number of shipments. Therefore, the shipment index is also applied to the ESAL values as previously done for cost and exposure measures. Table 14 shows that OWT 2 will create the least total highway damage among the cask/vehicle alternatives. Most pertinent here, the unit measure for the future OWT cask/vehicle design (OWT2) is about 15 percent lower than that for the future LWT cask/vehicle design (LWT2). 
It was briefly mentioned above that new AASHTO highway design procedures had recently been adopted. The new procedures treat tridem axles differently with respect to projected highway damage than the old AASHTO procedures. Although this is discussed in more detail in Appendix $D$, it is important to note here that the use of the new procedures is pivotal for the present comparative analysis of repository highway damage. Under the old AASHTO procedures, the ESALs computed for OWT 1 and OWT 2 would be substantially higher (14.51 and 18.07, respectively) than those shown in Table 14. Thus, $\mathrm{OWT}_{2}$ would have resulted in the greatest highway damage among the four alternatives, even after accounting for fewer shipments. Under the newer procedures, the order is reversed and OWT2 results in the least highway damage.

The FHWA is currently undergoing a public review process to determine if it should recommend the new AASHTO design procedures for Federal highway projects. However, formal FHWA approval is not required. State highway officials are now authorized to use the AASHTO procedures with or without a Federal review or recommendation. Consequently, it was decided to use the most current AASHTO design procedures for this analysis. The ESAL figures in Table 14 therefore reflect the new procedures adopted by AASHTO at its annual meeting in October, 1985. 
TABLE 14

COMPARISON OF IMPACTS

1. TRANSPORT COST

\begin{tabular}{|c|c|c|c|c|c|c|c|c|c|c|c|}
\hline \multirow[b]{3}{*}{$\begin{array}{l}\text { Cask } \\
\text { Type }\end{array}$} & \multirow{2}{*}{\multicolumn{2}{|c|}{ Shipping Costs }} & \multirow{2}{*}{\multicolumn{3}{|c|}{ Capital Costs }} & \multirow{2}{*}{\multicolumn{3}{|c|}{ Maintenance Costs }} & \multicolumn{3}{|c|}{ Total Transport Costs } \\
\hline & & & & & & & & & \multirow[b]{2}{*}{$\begin{array}{l}\text { Total Transport } \\
\text { Costs per } \\
\text { Shipment } \\
\text { (Shipping, } \\
\text { Capital, Maint) }\end{array}$} & \multirow[b]{2}{*}{$\begin{array}{l}\text { Shipment } \\
\text { Index }\end{array}$} & \multirow[b]{2}{*}{$\begin{array}{c}\text { Relative } \\
\text { Transpor } \\
\text { Cost (\$) }\end{array}$} \\
\hline & $\begin{array}{c}\text { Round } \\
\text { Trip } \\
\text { Distance } \\
\text { (miles) }\end{array}$ & $\begin{array}{c}\text { Tariff } \\
\text { Charge } \\
\text { per } \\
\text { Shipment }\end{array}$ & $\begin{array}{l}\text { Daily } \\
\text { Lease } \\
\text { Rate }\end{array}$ & $\begin{array}{l}\text { Total } \\
\text { Round } \\
\text { Trip } \\
\text { Time } \\
\text { (days) }\end{array}$ & $\begin{array}{c}\text { Total } \\
\text { Capital } \\
\text { Cost/ } \\
\text { Shipment }\end{array}$ & $\begin{array}{c}\text { Annual } \\
\text { Maint } \\
\text { Chg/Cask }\end{array}$ & $\begin{array}{c}\text { No. of } \\
\text { Shipments } \\
\text { per Cask/yr. }\end{array}$ & $\begin{array}{c}\text { Maint } \\
\text { Charge per } \\
\text { Shipment }\end{array}$ & & & \\
\hline $\mathrm{LWT}_{1}$ & 2,720 & $\$ 7,100$ & $\$ 1,500$ & 4.3 & $\$ 6,450$ & $\$ 75,000$ & 70 & $\$ 1,070$ & $\$ 14,620$ & 1 & $\$ 14,620$ \\
\hline $\mathrm{LWT}_{2}$ & 2,720 & 7,800 & 1,500 & 4.3 & 6,450 & 75,000 & 70 & 1,070 & 15,320 & 0.5 & 7,660 \\
\hline$O W T_{1}$ & 2,720 & 13,900 & 2,000 & 6.6 & 13,200 & 100,000 & 45.5 & 2,200 & 29,300 & 0.33 & 9,669 \\
\hline $\mathrm{OWT}_{2}$ & 2,720 & 14,100 & 2,000 & 6.6 & 13,200 & 100,000 & 45.5 & 2,200 & 29,500 & 0.25 & 7,375 \\
\hline
\end{tabular}

2. EXPOSURE TIME

\begin{tabular}{|c|c|c|c|c|c|c|c|c|}
\hline $\begin{array}{c}\text { Cask } \\
\text { Type }\end{array}$ & $\begin{array}{c}\text { One-Way } \\
\text { Distance } \\
\text { (miles) }\end{array}$ & $\begin{array}{c}\text { Average } \\
\text { Speed (mph) }\end{array}$ & $\begin{array}{c}\text { Total } \\
\text { Driving } \\
\text { Time (hrs) }\end{array}$ & $\begin{array}{c}\text { Total } \\
\text { Exposure Time } \\
\text { for 2 Drivers } \\
\text { (man-hrs) }\end{array}$ & $\begin{array}{c}\text { Facility Exposure - } \\
\text { Time for 3-4 } \\
\text { Crew (man-hrs) }\end{array}$ & $\begin{array}{c}\text { Total Time } \\
\text { of Exposure } \\
\text { (man-hrs) }\end{array}$ & $\begin{array}{c}\text { Relative } \\
\text { Shipment } \\
\text { Index }\end{array}$ \\
\hline LWT1 & 1360 & 35 & 39 & 78 & 84.8 & 162.8 & 1 \\
Time (man-hrs)
\end{tabular}

3. HIGHWAY DAMAGE

\begin{tabular}{|c|c|c|c|c|c|c|}
\hline $\begin{array}{l}\text { Cask } \\
\text { Type }\end{array}$ & $\begin{array}{c}\text { Axle } \\
\text { Weights }\end{array}$ & $\begin{array}{l}\text { Equivalent Std Axle Loads } \\
\text { (ESAL) Flexible Pavement }\end{array}$ & $\begin{array}{c}\text { Equivalent Std Axle Loads } \\
\text { (ESAL) Rigid Pavement }\end{array}$ & $\begin{array}{c}\text { Composite ESAL } \\
\text { (43\% Flexible Pavement } \\
57 \% \text { Rigid Pavement) }\end{array}$ & $\begin{array}{l}\text { Shipment } \\
\text { Index }\end{array}$ & $\begin{array}{l}\text { Relative } \\
\text { Highway } \\
\text { Damage }\end{array}$ \\
\hline LWT & $10-32.5-32$ & $0.1175+0.9411+0.8892=1.95$ & $0.082+1.591+1.491=3.16$ & 2.64 & 1 & 2.64 \\
\hline $\mathrm{LWT}_{2}$ & $11 \cdot 34-34$ & $0.1668+1.111+1.111=2.38$ & $0.122+1.919+1.919=3.96$ & 3.28 & 0.5 & 1.64 \\
\hline $\mathrm{OWT} \mathrm{T}_{1}$ & $12-47-52$ & $0.2287+0.992+1.439=2.66$ & $0.176+2.285+3.442=5.90$ & 4.51 & 0.33 & 1.49 \\
\hline $\mathrm{OWT}_{2}$ & $11-51-54$ & $0.1668+1.339+1.658=3.17$ & $0.122+3.183+4.003=7.31$ & 5.53 & 0.25 & 1.38 \\
\hline
\end{tabular}




\subsection{ANALYSIS OF ISSUES}

The information presented in the last three chapters raises a number of issues to be considered by DOE before major steps should be taken to develop an overweight truck cask. As a matter of presentation, these issues are conveniently grouped into three categories: issues involving Federal and State concerns over highway and bridge damage from heavy trucks, issues arising from State permitting, and issues relating to the repository program itself.

\subsection{FEDERAL AND STATE CONCERN OVER HEAVY TRUCKS}

The Federal and State governments are increasingly concerned with the impacts created by heavy trucks. These concerns include the deterioration of the nation's highways and bridges, the strong link between much of this highway damage and heavy trucks, the belief that heavy trucks avoid State weight enforcement efforts, the perception that heavy trucks do not pay their fair share of highway user fees, and the concern that heavy trucks may be unsafe. These concerns are included here as issues because they are part of the political environment which DOE should consider in the decision of whether to develop an overweight cask fleet.

\subsubsection{Growing Concern Over Highway and Bridge Deterioration}

As stated before, both State and Federal governments recognized in the 1970s that large sections of the Federal-aid highway system were in need of repair. The 20-year design life of a significant portion of Interstate highways was exceeded in the 1970s. Indicative of deteriorating conditions, the Federal Highway Administration (FHWA) changed the overall rating of the Federal-aid highway system from "good" to "fair" in 1975. States began shifting funds from new construction to highway rehabilitation and repair. This emphas is on maintenance of existing roadways rather than new construction has continued until today. 
Highway and bridge deterioration has been accelerated by increasing traffic of a 11 kinds. The heavy-truck component of total traffic has increased substantialiy since the 1950 s as indicated by truck registration data. Many State highway officials reported in a survey conducted by the General Accounting office (GAO) that they believed increasing heavy truck traffic to be a major cause of highway and bridge damage. Further, according to GAO figures, one of four loaded trucks on the highway is overweight (GAO, 1979 , p. 11). A U.S. Department of Transportation (DOT) study estimated that about 11 percent of a11 trucks (loaded and empty) are overweight (DOT, 1981a, p. III-20). These figures do not distinguish between overweight vehicles operating legally under permit and vehicles operating illegally.

By definition, overweight trucks reduce the serviceable life of a highway. As previously explained, pavements are designed for projected legalweight traffic loads. Any increase in axle loadings beyond this decreases serviceability of the pavement before the design life is attained. Consequent1y, many officials believe that widespread overweight shipments, whether legal or not, contribute greatly to advanced deterioration of highways.

The level of concern over the impact of truck weight on highways and bridge deterioration has been tempered somewhat by the findings of DOT in its report An Investigation of Truck Size and Weight Limits (DOT, 1981a). This comprehensive study was mandated by Section 161 of the 1978 Surface Transportation Assistance Act (STAA) and was completed in August of 1981. It investigated the global benefits and costs associated with nine alternatives involving size and weight limits. The largest cost savings came from the alternative to increase axle weights to 22,400 pounds for single axles and 36,000 pounds for tandem axles, and to replace the current Federal Bridge Formula B with the more liberal Bridge Formula $C$. This scenario was found to reduce average truck cost per ton-mile significantly, as well as to lower air pollution and save on fuel and energy. Cost savings from this increased truck productivity exceeded the increased bridge and pavement costs associated with higher weights. The study did point out that truck productivity savings could be eliminated if highway user fees were not raised to pay for the increased damage caused by higher axle and gross vehicle weights. 


\subsubsection{Heavy Truck Damage}

There is clear evidence that heavy trucks cause more highway and bridge damage than similarly designed lighter trucks. As discussed in Section 2.4, pavement damage increases exponentially with increased weight. However, this would ultimately depend on the exact axle configuration of the vehicles.

An analysis was conducted in Section 4.3 of relative highway damage caused by legal-weight and overweight truck shipments to repositories. The results, though somewhat inconclusive, indicate that the overweight truck option will reduce overall highway damage compared to the legal-weight option. This is based upon highway design procedures recently approved by the American Association of State Highway and Transportation Officials (AASHTO) as previously discussed. According to these procedures, the repository-related highway damage is about 15 percent less for future overweight truck (OWT) shipments than for future legal-weight truck (LWT) shipments over the life of the repository because of substantially fewer shipments. It should be noted that there is some disagreement over the relevance and validity of using the AASHTO procedures to compute representative highway damage. Serious consideration is now being given to conducting a new long-term pavement performance study as part of the Strategic Highway Research Program (SHARP) proposed by the Transportation Research Board. This would allocate up to $\$ 10$ million per year for up to 18 years to study the effects of axle weights and axle configurations on highway performance.

Regardless of the validity of the highway-damage calculations in Section 4.3, the amount of total repository-related traffic should be kept in perspective. Even in the unlikely event that all shipments go by truck, repository-related traffic over the thirty-year life of the repository would be a miniscule percentage of total truck traffic, or even total overweight truck traffic, over the same time period.

\subsubsection{Increased Federal Emphasis on \\ State Weight Enforcement}

States are responsible for enforcing vehicle size and weight limits on a 11 Federal and State roadways as noted earlier. However, there have been 
allegations that State enforcement efforts have not been effective and that a relatively high percentage of trucks are illegally overweight. Recent laws have given the Federal government more oversight on State weight enforcement activities. States are required to submit certifications to FHWA that they are enforcing weight 1 imits and to provide supporting data as well as report on overweight permitting. In turn, the FHWA is required to report on State enforcement activity to Congress each year.

According to DOT, it became apparent after some experience with the certification process that some States had very low levels of enforcement. This was based on low ratios of vehicle weighings to truck registrations and of citations to truck weighings. This spurred Congress in 1978 to adopt a penalty of 10 percent of apportioned highway funds if States fail to adequately enforce weight laws. The FHWA now also requires States to submit enforcement plans as well as certifications. Once again, GAO was very critical in its report, finding that many States devote only minimal resources to enforcement, that most fines and penalties are too low to deter violations, and that widely used permanent scales are ineffective because they are easily avoided.

In response to increasing public awareness and Federal pressure, many States have upgraded their enforcement efforts. It is inevitable that the concern over legal-weight enforcement has also caused States to become more stringent in granting overweight permits. It has been argued by some that liberal overweight permit policies serve to encourage violation of legal weights.

Another repercussion of increased weight-enforcement efforts is a crackdown on overweight shipment practices by Federal agencies and their contractors. Although DOT has no direct authority, it has encouraged other agencies to set an example for States by limiting overweight shipments to only where absolutely necessary. This includes DOE as discussed in Section 5.3.1.

\subsubsection{Heavy Trucks and Highway Costs}

A number of highway cost allocation studies by the Federal government and by many State governments have consistently found that the heavier trucks underpay their allocated costs. Even with the recent significant 
increase in truck-user fees in 1982, heavy trucks do not pay the ir share under the current cost allocation methodology. The American Trucking Associations, Inc. (ATA) does not agree with the methodology used in most of these studies and maintains that trucks pay a higher share than indicated. Nonetheless, the common perception among State highway officials is that heavy trucks do not pay high enough user fees, given the clear link between this class of vehicles and extensive highway damage and bridge stress.

\subsubsection{Concern Over Heavy Truck Safety}

FHWA is currently studying the safety implications of larger and heavier trucks. The differential between average automobile weights and truck weights is growing. Braking distances and speed maintenance on upgrades were reported by State officials in a GAO (1979) survey to be major problems for heavy trucks. These and other potential safety problems have not been fully studied. The results of current research on the safety aspects of heavy trucks may have a significant bearing on State attitudes toward overweight shipments.

\subsection{STATE PERMITTING}

There are a number of potential problems facing DOE in relation to State permit operations, many of which are apparent from the discussion in Section 3.2 of this report.

\subsubsection{Divisibility of Load}

An interpretation on the divisibility of a multi-element spent fuel cask will be important to the development of an overweight cask by DOE. If it is deemed to be a "divisible load" there could be legal and administrative obstacles at both the Federal and State levels.

A controversy currently exists as to whether certain States are restricted by Federal law from issuing divisible load permits for vehicles operating on the Federal-aid highway system. The 1982 STAA authorizes States to issue special permits for vehicles which exceed 80,000 pounds gross vehicle 
weight (GVW) if the load is considered nondivisible (i.e., cannot be "easily dismantled or divided"). Permitting for nondivisible loads is therefore clearly a State prerogative without regard to Federal restrictions. Thus, if a spent fuel cask with more than one fuel element is determined to be a nondivisible load, there is no Federal restriction on what States may allow under a special permit.

States are not authorized by the 1982 STAA to issue special permits for vehicles greater than 80,000 pounds GVW for divisible loads, except for one controversial condition. That condition again relates to grandfather rights for States that had permit authority for certain divisible-load weight 1 imits in effect when laws were changed in 1956. Many States now issue divisible load permits based on the authority of this grandfather clause. However, the FHWA maintains that not a11 such state authority is legitimate. Some States claim that grandfather rights apply if the States had legal authority to issue divisible-load permits in 1956, but had not done so at that time. The FHWA has consistently argued that States have divisible load permit authority only as it existed in 1956, and that such permit authority cannot be exceeded or expanded.

The GAO report on overweight trucks has recommended that the FHWA closely examine State interpretations on divisible load permits. GAO also presented its own interpretation to Congress maintaining that the grandfather clause does not authorize the issuance of permits on the basis that a State could have passed a permit law on July 1, 1956 but had not done so. DOT has stated its agreement with GAO (DOT, 1980):

The Department is in complete agreement with the GAO on these points and believes that a state may not exceed its Ju1y 1, 1956 permit authority without violating 23 U.S.C. 127. This includes ... authorizing permits for divisible loads when only non-divisible or non-reducible load permits were previously authorized.

Twenty-three States currently issue divisible load permits. The number of States that have legitimate grandfather rights that allow them to issue such permits is now under review by the FHWA.

The divisible load rule is obviously subject to different interpretations and remains highly controversial. The FHWA has never been able to resolve the differences of opinion and the matter is currently being litigated 
by the Truck Weight Advisory Council, the State of South Dakota, and others. The resolution of this controversy could have a serious impact on DOE policy on developing an OWT cask. If the FHWA interpretation is correct, and if a multi-element spent fuel cask is determined to be a divisible load, then many States would not be allowed to permit nuclear OWT casks even if they so desired.

In addition to the Federal statute, some State laws specifically prohibit divisible load overweight permits. At least 20 States do not issue divisible load permits, although some do provide a statutory exception for certain commodities (often of local or regional economic importance such as logging or coal). Thus, even if the Federal divisible load rule is resolved in favor of OWT permitting, a number of State statutes must also be overcome.

Obviously, the key for DOE to eliminate these potential obstacles is to have the multi-element spent fuel cask recognized as a nondivisible load for purposes of State permitting. As discussed in Section 4.1, some State representatives have argued in the past that the mere presence of more than one fuel element inside the cask makes the entire shipment a divisible load, for which permits may not legally be issued in some States. Industry has argued in the past that a spent fuel cask is nondivisible regardless of the number of fuel elements inside the cask. It has maintained that the divisible load rules apply to the shipment, not the package. Only one cask is being shipped at a time and it cannot be dismantled or divided. Furthermore, industry has argued that a cask that is overweight when empty (as would be the case with prospective OWT casks) makes the number of fuel elements inside irrelevant when considering divisibility. The shipment would be overweight, thus requiring a State permit, whether it has $0,1,2$, or more fuel elements. Despite the past reservations of some State officials, States have issued overweight permits for a variety of packagings containing nuclear waste and multi-element spent fuel casks. Tri-State Motor Transit Company (TSMT), Home Transport, and other carriers routinely obtain permits and transport packagings containing bulk low-level nuclear waste, which conceivably could be reduced in weight to legal limits. As discussed in Chapter 4 of this report, States have issued overweight permits for a number of spent fuel shipping campaigns involving multi-element casks. An official of TSMT reported that, 
to his knowledge, no State had ever refused to issue an overweight permit on the basis of load divisibility for a multi-element cask.

A more recent argument on load divisibility has to do with timing.

Some argue that permits are issued now only because overweight multi-element casks have already been built and nothing can be done now about their design. However, DOE is early in the cask development stage and has the option to build a multi-element cask that is legal-weight as well as one that is overweight. DOE should consider the fact that some States could argue that future multi-element spent fuel casks that are purposely designed to be overweight should be considered a nonpermittable divisible load since they could have been designed as legal-weight casks.

\subsubsection{Optimum Gross Vehicle Weight for Permitting}

Assuming that legal questions concerning divisibility of a multielement cask are surmounted, the next question involves the type of cask that is likely to be permittable in the greatest number of States. Ideally, an overweight spent fuel cask should be permittable by a11 48 contiguous States, as well as by all toll facilities and localities that enforce weight limits. This may not be possible given the physical requirements necessary to accommodate a four-element pressurized-water reactor (PWR) or ten-element boilingwater reactor (BWR) spent fuel cask.

As discussed in detail in Sections 3.2 and 4.2 , State weight limits allowable under special permits vary greatly and can be confusing because of terminology. To account for the different State practices and definitions, this report identifies "practical maximum" permit weights for different axle configurations based upon carrier operating experience.

The maximum gross vehicle weights allowed under permit in most States are tied to individual axle weights and axle spacing requirements. Thus, the key to obtaining approval for a desired GVW is to comply with maximum permittable single, tandem, or tridem axle limits as appropriate, and to stay within the axle spacing requirements dictated by the State bridge formulas or tables. Of particular importance in most states is compliance with the inner and outer bridge formula weights as discussed in Section 3.1. The 
practical maximum permit weight limits identified in Figure 1 reflect State axle limits and axle spacing requirements.

Recent carrier experience and past nuclear OWT shipping campaigns show that many States have issued permits for shipments in the range of 90,000 to 112,000 pounds gross vehicle weight. This includes the West valley, New York, to Oyster Creek, New Jersey, move at approximately 111,600 pounds. The States have also approved tridem axle weights in the range of 50,000 to 52,000 pounds for these shipments.

Figure 1 shows a range of permittable weights depending upon the axle configurations based upon TSMT data. Future tractor/trailer configurations to accommodate OWT casks will probably require from 6 to 9 total axles. Figure 1 indicates that the closest to 100 percent certainty of qualifying for a State permit is a 6-axle configuration with a gross weight of 96,000 pounds. However, it is not apparent that cask weights and/or trailer weights and axle arrangements can be such that four-element PWR casks or ten-element BWR casks could be shipped at 96,000 pounds GVW. The addition of either another axle or more weight would quickly lower the number of States that would accept this option on a routine basis.

The representative cask/vehicle design discussed in Section 4.3 is a 7-axle combination vehicle with two tridem axles. This design could accommodate up to 116,000 pounds as previously discussed. However, it may not be possible to obtain a permit in as many as 10 States without special arrangements or agreements with each of the States.

It appears that a 7-axle combination vehicle with a GVW not greater than about 110,000 pounds is the most desirable vehicle configuration and optimum cask weight according to Figure 1 based upon TSMT data. This arrangement could be permitted in at least 90 percent of the States. This would still leave five States to be approached for special arrangements or agreements.

\subsubsection{Changes in State Permit Policies Over Time}

Vehicle size and weight limits have a great economic impact on the commercial motor carrier industry. Shippers are also vitally affected. There has been continual pressure from both shippers and carriers to increase 
trucking productivity since the beginning of the industry. One way to do this is to increase the payload for each trip by allowing longer or wider vehicles, more trailers, or greater weight. On the other hand, highway damage caused by heavy trucks, safety questions involving the maneuverability and braking of long and heavy trucks, and the amount of public investment in highways have become visible issues in most State legislatures.

The net result of this dynamic environment is that State policy on vehicle size and weight controls can, and will, change over time. This change could result from different State administrations, political pressure from industry or from environmental or safety groups, or even from economic events external to the political process. As an example, the oil shortage of the early 1970's brought about new and higher legal-weight limits at the State and Federal level.

Changing State policy on vehicle size and weights could affect State overweight permit policies as well as legal-weight limits. A newly elected executive branch may decide it does not agree with the previous administration's policies on overweight vehicles and initiate changes in regulations and procedures by its highway weight control agency. This could adversely affect overweight truck shipments to repositories at some time in the future even though overweight casks are developed on the basis of agreements and policies between DOE and individual States established in the 1980's.

\subsubsection{Off-System Highways and Bridges}

Highways and bridges which are not eligible for Federal matching funds are referred to as "off system" highways and bridges. Off-system bridges, in particular, have received much attention recently from Congress and State authorities and extensive problems have been documented in a recent GAO report (GAO, 1983). Generally, off-system bridges are built to a lower design standard and receive a lower maintenance priority than Interstate and other Federal-aid bridges. As discussed in Section 2.4, many off-system bridges are protected from overstress by bridge posting at lower weight limits.

Off-system highways and bridges may present the greatest permitting problem for DOE. It is very conceivable that a properly designed OWT shipment 
that complies with Federal and State bridge formulas can be permitted by States on a routine basis for operation on the Federa1-aid system. However, States are very concerned about the condition of off-system highways and bridges that are not eligible for Federal funds and that are the most vulnerable to overloads. Most reactors and a 11 potential repository sites are located off the Federal-aid system. Thus, connecting roadways and bridges could present a critical obstacle to State permitting, even though 98 percent of the shipment will be on the Federal-aid system roads and eligible for permits.

\subsubsection{Administrative Constraints}

In addition to questions involving whether permits can be obtained, several administrative constraints involving State permitting procedures and requirements should be considered.

5.2.5.1 Nonuniformity in State Permit Procedures. As discussed throughout Section 3.2, permit procedures and requirements vary widely. This general nonuniformity among the States has frustrated carriers for years. Despite calls for development of uniform State weight control practices by FHWA, AASHTO, the Transportation Research Board, and others, it is not likely that the situation will be much different in the years ahead.

State procedures and requirements vary on virtually all aspects of weight control: type and duration of permit; allowable axle and gross weights, and axle spacing; permit restrictions involving time controls and routing; permit fee structures; financial responsibility; and permit application and approval procedures. The differences are discussed generally in Section 3.2 and enumerated in detail in Appendix A. This nonuniformity is costly and burdensome in and of itself. Should DOE pursue the development of an overweight cask and conduct OWT operations on a routine basis, it will have to commit resources to become thoroughly apprised of this array of permit controls for virtually every State and turnpike authority, as well as for some localities. 
5.2.5.2 Repetitive, Single-Trip Permits. It is likely that most States will not issue blanket or multiple-trip permits to cover an entire spent fuel shipping campaign. Single-trip permits will probably have to be obtained for each round trip. Since many shipments could involve 5 to 10 States (plus turnpike and possibly some local weight approval), this will place a repetitive administrative and paperwork burden on DOE and the carriers.

However, much of the repetitive nature of obtaining single-trip permits can be overcome by developing routine procedures between shippers and carriers, and each affected State weight authority. This is typical for the motor carrier industry in making other types of overweight shipments. Once State authorities become familiar with the type of overload and have had a chance to observe a few movements, permit processing usually becomes routine. Since most of the repository shipments will involve multiple shipments between a specific reactor and the repository site, the permit processing should become routine after the first few shipments even if repetitive single-trip permits are required.

\subsection{PROGRAM CONSIDERATIONS}

This group of overweight truck issues relates to repository transportation requirements or general1y to the DOE transportation program.

\subsubsection{Current DOE Overweight Truck Policy}

DOE has stated its general overweight truck policy clearly on several occasions. It provides that its contractors may not ship any item overweight until DOE has determined that it is not practical to further divide the load, nor feasible to use another mode of transportation. As discussed in Section 2.2, this policy has been expressed to the House Ways and Means Committee, DOT, and to private industry, and is also embodied in DOE Order 1540.1 (DOE, 1982). Traffic managers at each DOE Operations Office have 
followed this policy for years and, based upon a recent survey, are generally opposed to overweight shipments.*

Recentiy, the DOE Office of Defense Programs went one step further and expressed DOE policy specifically on developing an OWT cask (see Section 2.2 for specific language). DOE stated that radioactive material cask design would balance the benefits of reduced shipments with the cost of possible highway damage, and that appropriate State officials' review and comment on overweight cask design would be solicited.

The first policy statement may present several problems for DOE if it intends to develop an OWT cask. The DOE policy reinforces the problems just discussed on State permitting for divisible loads. It says that DOE wi11 not even request State permits if a divisible load is involved. Thus, DOE must either change this policy provision or convince Federal and State officials that a multi-element cask is a nondivisible load. Also, the DOE has imposed an additional restriction on itself by specifying the nonavailability of other modes as a prerequisite for requesting State permits. This provision will almost certainly have to be revised unless DOE intends only to use OWT for reactors without any rail and water alternatives.

Another provision of the DOE policy is the commitment to seek State review and comments on cask design. This process could be useful for addressing many of the problems discussed in this report. Issues involving the political sensitivity of heavy trucks and highway damage, legal questions on load divisibility, optimum cask weight for permitting, and State permitting problems could be discussed well in advance.

\subsubsection{Cost and Risk Impacts}

The potential for overweight truck casks to reduce cost and risk impacts compared with legal-weight truck casks for the repository program was

\footnotetext{
* Results of a survey questionnaire mailed to DOE field office traffic managers indicate general opposition to overweight truck shipments. Principal concerns are the loss of control over a shipment to State weight authorities, the introduction of potential new legal obstacles involving unnecessary overweight restrictions, and questions about the cost efficiency of OWT over LWT. See Appendix $E$ for specifics on the questionnaire and replies.
} 
briefly evaluated in Section 4.3. Because of the importance of occupational exposure in normal transport exposure (which dominates total radiological risk), occupational exposure time was evaluated as representative of risk. It was seen that the representative 4 PWR/10 BWR OWT cask has the potential to substantially reduce worker exposure from that of LWT cask alternatives because of reduced exposure time. Exposure time was reduced because fewer shipments were required, even though transit times and facility exposure times were longer.

Cost components evaluated included shipping cost, capital cost, and maintenance cost. After accounting for the reduced number of shipments for the OWT options, the low-cost alternative was the representative future 4 PWR/10 BWR overweight cask. However, the cost advantage of the 4 PWR/10 BWR OWT cask over the 2 PWR/5 BWR legal-weight cask was found to be relatively sma11. It should be stated that the numbers and assumptions used for certain cost comparisons are tentative and, in some cases, may be outdated due to ongoing research by DOE. This applies especially to cask lease rates and turnaround times. Conceivably, the results of the cost comparison could change based upon new data.

The results of this preliminary cost analysis, in conjunction with other findings in this report relating to cost, should be of some concern to DOE. TSMT tariff data indicate that shipping charges are 12 percent higher for OWT than for LWT for both empty and loaded moves. Higher security costs and State OWT permit fees increase the cost differential between LWT and OWT. Recent nuclear OWT campaigns show that State permit time restrictions reduce average vehicle speed for OWT shipments, thus increasing transit time. Facility turnaround times also appear to be longer for OWT shipments. Of particular concern should be TSMT experience that vehicle detention charges for some recent West Valley OWT moves have been as much as 150 percent of freight charges (compared to an average of 20 percent for LWT shipments). Also, recent cost comparisons between OWT and LWT shipments by DOE traffic managers show higher costs for some overweight moves. Despite all of the foregoing, the analysis conducted in this report shows the OWT option to be slightly more cost-effective than LWT, principally because of the reduced number of shipments required. However, the margin is small enough that a change in one key assumption could affect the comparison. DOE should consider 
conducting a more extensive cost comparison between OWT and LWT shipments using new input data and existing logistics models.

\subsubsection{Shipping Schedules}

There are several aspects of utilizing overweight casks that could have significant effects on repository shipping schedules. First and most important, time restrictions from State overweight permits will greatly influence transit times. Almost all States have permit provisions that do not allow travel at night or on weekends and holidays. This will lengthen almost all shipments. Another cause of increased transit time is the cumbersome procedure of applying for and obtaining permits from all the various States involved in a move. As illustrated previously, this can be time-consuming. Facility turnaround times will also be longer for OWT casks. All of these factors, discussed in Section 3.2, will impact shipping schedules and cask utilization.

Another type of permit time restriction may also play an important factor for reactors located in the North. Frost laws restrict movement of heavy vehicles in many of these States during the spring and fall seasons. Some States reduce legal-weight limits and others temporarily cancel overweight permits. Again, this could impact shipping schedules.

It should be noted that time restrictions, especially night and weekend prohibitions, could be waived under special agreements by many States. This has been done in the past for some cross-country nuclear OWT movements. Also, the process of obtaining approval for any type of nuclear waste shipment today is time-consuming, whether it involves LWT casks or OWT casks. This has removed some of the time advantages of LWT casks over OWT casks.

\subsubsection{Loss of Control}

A more subtle program impact caused by the use of overweight casks has to do with a loss of some control of the shipment to State and local governments. Once a load is subject to overweight permit provisions, it falls almost completely under the control of State weight officials and enforcement personne?. 
Under normal legal-weight operations, nuclear shipments are subject to extensive Federal transportation regulations like any other hazardous material. Some State and local governments have implemented restrictions over the past several years for nuclear shipments that shippers and carriers have found objectionable. Many of these restrictions are preempted by Federal laws governing hazardous material transportation, principally the Hazardous Materials Transportation Act (HMTA). For example, routing of certain radioactive materials cannot be prescribed in an arbitrary fashion by a State. The DOT HM-164 rulemaking, promulgated pursuant to the HMTA, established a procedure for determining routes (DOT, 1981b). However, HM-164 provisions are applicable based upon the hazardous nature of the cargo, not upon the weight of the vehicle. State weight authorities could, therefore, prescribe routes for overweight nuclear shipments as they deem appropriate for any type of overload, regardless of the routing framework established by HM-164. Routing is just one example of a number of operational procedures that fall under the sole authority of State weight officials once a shipment requires a State OWT permit. 


\subsection{CONCLUSION AND RECOMMENDATIONS}

As discussed in the introduction to this report, there are a number of reasons for the U.S. Department of Energy (DOE) to pursue the deveiopment of an overweight truck cask to serve the repository program. Regardless of the final modal strategy selected by DOE, it is certain that truck shipments of some type will be necessary. Thus, the payload limitation of truck casks becomes a crucial factor. Existing legal-weight cask payloads are limited to one pressurized-water reactor spent fuel element or two boiling-water reactor spent fuel elements ( 1 PWR/2 BWR), and future legal-weight cask payloads may not exceed 2 PWR/5 BWR elements. Potential future overweight cask payloads of 4 PWR/10 BWR elements offer the promise of substantially fewer highway shipments. However, the apparent advantages of overweight casks must be evaluated in light of the issues presented and discussed in this report.

The first set of issues identified in Chapter 5 relates to Federal and State concerns with heavy trucks in general. Some of these issues can be mitigated to a certain extent by other factors or by DOE actions. The concern over deteriorating Federal-aid highways and bridges, and the relationship between this deterioration and heavy trucks creates a difficult environment for DOE to seek consensus for repository-related nuclear overweight truck (OWT) operations. However, this concern is mitigated by evidence that OWT operations may cause less total highway damage than legal-weight, and that total repository-related truck traffic will be a small fraction of total heavy truck traffic in the future. Concerns that State enforcement of overloaded trucks is inadequate, and that heavy trucks are unsafe, can be diminished to some extent by the fact that nuclear OWT shipments will be under permit controls that dictate routes, speed, time, and other conditions. The concern that heavy trucks do not pay high enough user fees could be resolved through specialiy negotiated permit fees for the nuclear overweight shipments. In sum, despite the overall adverse political environment represented by Federal and State concerns over heavy trucks in general, it is believed that many concerns can be diminished or even overcome.

The second set of issues discussed in Chapter 5, involves State permitting. These issues present more formidable obstacles than the general 
political environment discussed above. The administrative constraints involving State permitting, i.e., dealing with nonuniform procedures and the need for obtaining repetitive single-trip permits, could become quite burdensome but are surmountable with program planning and shipping experience. However, the fact that State vehicle-weight policies will change over time, and that some local governments and turnpike/bridge authorities have permit autonomy could result in serious problems in the future. Although not all such problems can be eliminated in advance, DOE could resolve some of these in its early planning by negotiating formal Federal-State agreements.

Another important State permitting issue will be maximum allowable permit weight. Without belaboring the obvious, the lower the gross vehicle weight the better. Even more crucial, however, will be individual axle weight and axle spacing. As discussed in Chapter 5, if OWT cask/vehicle systems can be developed such that State permit limits on single, tandem, and tridem axles are not exceeded, and the vehicle meets applicable bridge formulas, there wil1 be greatly reduced opposition to the issuance of State permits. Further, if the gross vehicle weight can be kept below 110,000 pounds, widespread State permit acceptance may be possible. The one potential permitting barrier could be physical limitations of crucial off-system roads and bridges. These roads and bridges are not eligible for Federal aid and are the most vulnerable to overloads. State and local officials are extremely reluctant to permit overweight movements over these facilities. These need to be independently evaluated by DOE.

The last, and most uncertain, State permitting issue is load divisibility. Two issues to be addressed are (1) whether a multi-element spent fuel cask is a divisible load, and (2) whether certain States can legally issue a divisible load permit to allow operation on the Federal-aid system. Preferably, DOE should encourage the standardized interpretation that a multielement cask is a nondivisible load to avoid the legal uncertainty involved with the latter issue.

It is true that multi-element casks have been permitted in the past by many States and that the TN-8 and TN-9 casks are current $1 \dot{y}$ being used for nuclear campaigns under State permits. However, this is not a good reason to ignore the issue of load divisibility. Some States have expressed opinions in the past that multi-element casks are divisible loads and that some States 
cannot issue divisible load permits because of either Federal restrictions or State laws. Because of unsettled legal questions, there is enough confusion and vagueness in this area that it would be prudent to address load divisibi1ity as soon as practicable.

The third set of issues discussed in Chapter 5 involves repository program considerations. The current DOE overweight shipment policy includes two self-imposed limits on overweight shipments, including load nondivisibility and nonavailability of other modes. These could be resolved by seeking the standardized interpretation that multi-element casks are nondivisible and by relaxing the restriction on use of other modes. Repository shipping schedules could be affected by State OWT permit restrictions involving nights, weekends, holidays, and, for some northern States with frost laws, the seasons of early spring and late fall. These time restrictions also affect transport cost and risk as well as scheduling. However, as noted before, the increasing restrictions and time associated with all types of nuclear shipments may be reducing the relative time advantage of legal-weight shipments over overweight shipments. The analysis conducted in Section 4.3.2 illustrates that overweight shipments could substantially reduce occupational exposure time, and by inference, overall transport risk. The cost analysis also showed that overweight shipments have the potential to reduce transport cost over the life of the repository program, particularly if agreements can be reached with State officials to minimize permit time restrictions. The last issue relating to program considerations is the potential loss of control by DOE over the nuclear shipments since overweight shipments are under almost total control by State weight authorities.

Based upon the above discussion, it is apparent that there are a number of potential problems relating to overweight trucks casks that should be addressed by DOE. Nevertheless, the overall conclusion of this study is that, although some of these problems are serious, they should not preclude further consideration of the OWT option by DOE at this time. Early development of the overweight cask concept, however, should be closely coordinated with parallel DOE activities to resolve key issues. It is recommended that DOE take the following actions to address these issues: 
1. Establish a top-level working group on overweight nuclear shipments.

The purpose of this group would be (1) to foster the development of a clear national consensus for repository-related OWT shipments, (2) to resolve legal questions and interpretations, and (3) to mitigate political sensitivity associated with heavy trucks and deteriorating highway conditions. This group should consist of representatives from DOE, Federal Highway Administration (FHWA), American Association of State Highway and Transportation Officials (AASHTO), and a carrier organization as the core group. The key issues which this group needs to focus upon include the following:

- Interpretation on the divisibility of a multi-element spent fuel cask

- Legal interpretation on the ability of States to issue divisible load permits

- The need to obtain near unanimity among States on maximum allowable permit weights and vehicle configurations

- The near for virtual certainty among a11 States that repetitive OWT permits will be available and State permitting policy will be consistent over time.

All of these issues will probably require formal resolution. Options available are (1) Federal or State regulatory interpretation or rule change; (2) changes in Federal or State law; or (3) forma 1, written agreements between DOE and State governments. One responsibility of the working group would be to recommend to DOE the most appropriate method of resolving issues identified in this report or to point out areas where resolution may not be possible.

2. Proceed with early planning to develop overweight cask designs.

Early conceptual designs for overweight casks should continue to be developed along with legal-weight truck casks, rail casks, and other cask concepts. However, DOE should coordinate all OWT cask development activities with the OWT working group recommended above. This should include participation by State weight authorities (possibly via the AASHTO representatives on the working group) as currently suggested by the DOE policy statement on overweight shipments.

Cask and vehicle designers should be encouraged to consider the following:

- Axle weights should not exceed single, tandem, tridem axle permit limits prescribed by almost all States 
- Axle spacing should allow compliance with Federal and State bridge formulas under almost any situation

- Gross vehicle weight should idea11y be kept to 110,000 pounds or less to enhance chances of universal permit acceptance.

3. Re-examine current DOE overweight truck policy.

DOE may be imposing unnecessary restrictions on itself by specifying that other modes of transport must be unavailable before overweight permits will be sought from State authorities. This may have to be changed or DOE needs to provide an exception for repository-related shipments.

4. Inventory off-system bridge and hiqhway limitations for each reactor and repository site.

As previously discussed, 98 percent of a route may a1low for permitting because it is on Interstate or other Federal-aid highways and bridges, which are built and maintained to higher standards than those for off-system facilities. However, an overweight shipment may be impossible because of the condition or physical limitations of the 2 percent of the route that is on non-Federal-aid highways and bridges. DOE needs to conduct an inventory of off-system road and bridge conditions for each reactor (especially those without rail or water access) and repository location. This includes potential monitored retrievable storage facility locations if approved by Congress.

5. Conduct case analysis of an upcoming overweight shipping campaiqn.

A detailed case analysis of an upcoming overweight shipping campaign would allow the documentation of the State-permit approval and issuance process, scheduling considerations, time and route restrictions, occupational exposure times, turnaround times, and costs involved with overweight shipments for detailed comparison with legal-weight shipments. 


\subsection{REFERENCES}

AASHTO, see American Association of State Highway and Transportation Officials.

American Association of State Highway and Transportation Officials, 1972. AASHTO Interim Guide for Design of Pavement Structures, Washington, DC (Chapter III, Rev., 1981).

American Association of State Highway and Transportation Officials, 1977. Standard Specifications for Highway Bridges Adopted by AASHTO, 12th Edition.

American Association of State Highway and Transportation Officials, 1985. Proposed AASHTO Guide for Design of Pavement Structures, NCHRP Project 20-7/24, National Cooperative Highway Research Program, Washington, DC.

Anderson R. T., 1981. Studies and Research Concerning BNFP. Nuclear Transportation Studies Related to Use of the Barnwe11 Nuclear Fuel Plant, AGNS-35900-1.4-161, A11ied-General Nuclear Service, Barnwe11, SC, for U.S. Department of Energy, Waste and Fuel Cycle Technology Office.

Anderson, R. T., D. G. Darr, W. L. Godfrey, R. B. Keely, E. C. Lusk, R. W. Peterson, J. L. Ridihalgh, F. A. Shai10, and M. Young, 1978. Current Status and Future Considerations for a Transportation System for Spent Fuel and Radioactive Waste, Y/OWI/SUB-77/42513, A11ied-Genera1 Nuclear Services, Barnwe 1T, SC.

Anderson, R. T., and J. B. Maier, 1979. Studies and Research Concerning BNFP. Nuclear Spent Fuel Transportation Studies, Allied-General Nuclear Services, Barnwe 11, SC, for U.S. Department of Energy, Fuel Cycle Project Office.

Best, R. E., J. H. Allen, P. A. Aucoin, G. D. Ball, C. C. Hoffman, M. E. Mason, W. A. Propes, and T. A. Vizzini, 1977. Capabilities of U.S. Domestic Transportation Systems for the Shipment of Radioactive Wastes, Y/OWI/SUB-77/22330, Nuclear Assurance Corp., At lanta, GA, for Office of Waste Isolation, Oak Ridge, TN.

DOT, see U.S. Department of Transportation.

GAO, see U.S. General Accounting Office.

Garrison, Roy, 1983. Letter from Garrison, Manager, Transportation Operations and Traffic, U.S. Department of Energy, to Leo Macklin, Transnuclear, Inc., June 1.

Gibbons, Sam M., 1979. Letter from Congressman Gibbons, Chairman of the House Ways and Means Subcommittee on Oversight to the Honorable James R. Schlesinger, Secretary of Energy, July 30. 
Gillogly, C. 0., 1984. Tri-State Motor Transit Co., Docket No. MC-109397 and Subs; Naming Specific Truck load Commodity Rates, also Specific Truck load Commodity Rates Applying on Radioactive Materials, Related Articles Classified or Declared Sensitive by the United States Government, and Empty Radioactive Material Containers, from, to, between a 17 Points and Places in the United States Except Alaska and Hawai 1 , ICC TSMT 4007-A, Interstate Commerce Commission, Joplin, MO.

Hoover, William W., 1984. Memo from Hoover, Assistant Secretary of Defense Programs, DOE to other program offices, November 29.

Keller, J. J., \& Associates, Inc., 1984. Vehicle Sizes and Weights Manual, Keller Regulatory Publications, Neenah, WI.

Neuhauser, K. S., J. W. Cashwe11, P. C. Reardon, and G. W. McNair, 1984. A Preliminary Cost and Risk Analys is for Transporting Spent Fuel and HighLeve 1 Waste to Candidate Repository Sites, SAND84-1795, Sandia Nationa 1 Laboratories, Albuquerque, NM.

Schlesinger, James R., 1979. Letter from the Honorable Schlesinger, Secretary of Energy, to The Honorable Brock Adams, Secretary of Transportation, February 2.

SINB, see Southern Interstate Nuclear Board.

Southern Interstate Nuclear Board, 1970. Proceedings of the Conference on Transportation of Nuclear Spent Fuel (February 5-6, 1970, Atlanta, GA).

Transportation Research Board, National Research Counci1, 1980. Motor Vehicle Size and Weight Regulations, Enforcement and Permit Operations, National Cooperative Highway Research Program Synthesis Report 68, Washington, DC.

TRB, see Transportation Research Board.

U.S. Congress, House Committee on Ways and Means, 1978. Impact of Truck Overloads on the Highway Trust Fund, Hearings Before the Subcommittee on Oversight, 95th Congress, 1st Session.

U.S. Department of Energy, 1982. Materials Transportation and Traffic Management, DOE Order 1540.1, Washington, DC.

U.S. Department of Energy, 1984. Draft Environmental Assessment (environmental assessments for nine sites); Nuclear Waste Policy Act (Section 112), DOE/RW-0009 through DOE/RW-0017, Office of Civilian Radioactive Waste Management, Washington, DC.

U.S. Department of Transportation, 1980. Overweight Vehicles-Penalties and Permits; An Inventory of State Practices, Report to Congress from the Secretary of Transportation, Federal Highway Administration, Washington, DC. 
U.S. Department of Transportation, Office of the Secretary, 1981a. An Investigation of Truck Size and Weight Limits, Final Report, of the Secretary of Transportation to U.S. Congress Pursuant to Section 161 of Public Law 95-599, The Surface Transportation Assistance Act of 1978, D0T-P-30-82-07, Washington, DC.

U.S. Department of Transportation, Research and Special Programs Administration, 1981b. "Radioactive Materials; Routing and Driver Training and Routing Exemptions," Docket HM-164, Federal Register, Vol. 46, No. 12, pp. 5298-5318, January 19.

U.S. Department of Transportation, 1982. Final Report on the Federal Highway Cost Allocation Study. Report of the Secretary of Transportation to the U.S. Congress Pursuant to Section 506 of Public Law 95-599, The Surface Transportation Assistance Act of 1978, Federal Highway Administration, Washington, DC.

U.S. Department of Transportation, 1984a. Alternatives to Tax on Use of Heavy Trucks; Surface Transportation Act of 1982, Section 513(G), Federal Highway Administration, Report to Congress, HPP-13/1-84(1-M)EW, Washington, DC.

U.S. Department of Transportation, 1984b. Overweight Vehicles-Penalties and Permits; An Inventory of State Practices, Report to Congress from the Secretary of Transportation, Federal Highway Administration, Washington, DC.

U.S. General Accounting Office, 1979. Excessive Truck Weight: An Expensive Burden We Can No Longer Support. And Questionnaire Summary, CED-79-94, CED-79-94A, U.S. Comptroller Genera 1, Washington, DC.

U.S. General Accounting Office, 1983. Limited Funds and Numerous Deficient Off-System Bridges Create Federal Bridge Program Dilemma, GAO/RCED-84-66, Report to the Secretary of Transportation, Washington, DC. 
APPENDIX A

STATE PERMIT REQUIREMENTS FOR OVERWEIGHT VEHICLES AND PERMIT REQUIREMENTS FOR TOLL ROAOS 
STATE PERMIT REQUIREMENTS FOR OVERWEIGHT VEHICLES

\begin{tabular}{|c|c|c|c|c|c|c|c|c|c|c|c|c|c|c|c|c|}
\hline 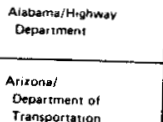 & 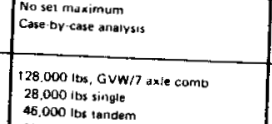 & 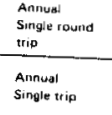 & $\begin{array}{l}\text { Year } \\
5 \text { days }\end{array}$ & Fixed tee & 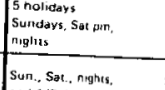 & Fog, cce, snow & $N / S$ & 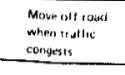 & $\begin{array}{l}\text { Perinum } \\
\text { specitites }\end{array}$ & No & No & $\begin{array}{l}\text { Perumit w" } \\
\text { werlice }\end{array}$ & s300.000 usuruance & \begin{tabular}{|l|} 
No \\
\end{tabular} & $N / S$ & 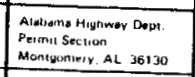 \\
\hline $\begin{array}{l}\text { Arizonal } \\
\text { Devartment of } \\
\text { Transportation } \\
\text { Arkansas/thighway } \\
\text { Departrment }\end{array}$ & 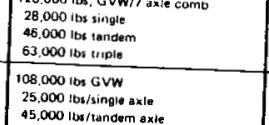 & Singlis rip & $\begin{array}{l}\text { Peat } \\
\text { N/S }\end{array}$ & $\begin{array}{l}\text { Fixed tee plus } \\
\text { weight charge }\end{array}$ & 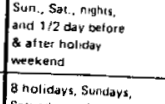 & $\begin{array}{l}\text { Snow, ice, averere } \\
\text { wealter , }\end{array}$ & $95 \mathrm{mph}$ & - & 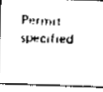 & No & No & $\begin{array}{l}\text { Perrmititin } \\
\text { vefuclie }\end{array}$ & $\mathrm{N} / \mathrm{s}$ & No & 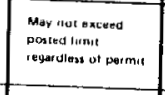 & 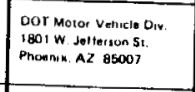 \\
\hline 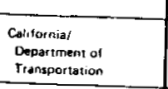 & 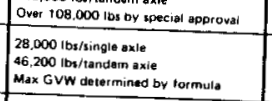 & $\begin{array}{l}\text { Annual } \\
\text { Single ritip }\end{array}$ & $\begin{array}{l}\gamma_{\text {ven }} \\
6 \text { datys }\end{array}$ & Fixeou Fee & | & inclement weather & N/S & - & 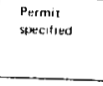 & $N / s$ & Nis & $\begin{array}{l}\text { Permitin } \\
\text { venticle }\end{array}$ & $\mathrm{N} / \mathrm{S}$ & Nis & 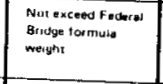 & 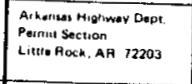 \\
\hline 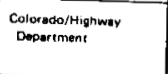 & $\begin{array}{l}\text { No ser maximum } \\
\text { Cose by case onalysis }\end{array}$ & $\begin{array}{l}\text { Annual } \\
\text { Singlat trig }\end{array}$ & $\begin{array}{c}\text { Year } \\
\text { N/s }\end{array}$ & $\begin{array}{l}\text { Fixed fiee plus } \\
\text { sale charge }\end{array}$ & $\begin{array}{l}\text { brolddays, weekends, } \\
\text { nights N/S }\end{array}$ & $\begin{array}{l}\text { Fog. (allit, winc inat } \\
\text { causes swave, we. } \\
\text { snow, frosi }\end{array}$ & $\mathrm{N} / \mathrm{s}$ & - & 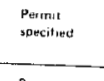 & No & No & $N / S$ & $\begin{array}{l}\text { Ai damages to highwav? } \\
\text { structures }\end{array}$ & No & 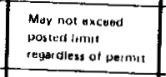 & 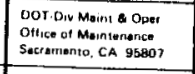 \\
\hline 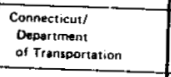 & 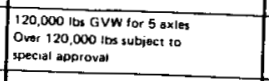 & $\begin{array}{l}\text { Annual } \\
\text { Single rip }\end{array}$ & $\begin{array}{l}\text { Year } \\
3 \text { dary }\end{array}$ & Fixed fee & 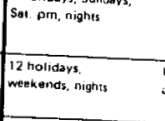 & 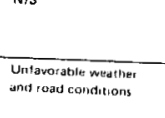 & $-\frac{N / S}{N / S}$ & $=$ & 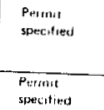 & No & $-{ }_{\text {No }}^{\text {No }}$ & 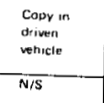 & 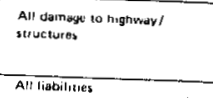 & No & N/S & 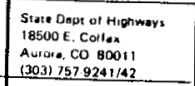 \\
\hline 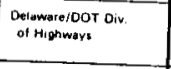 & 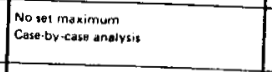 & Single tris & $N / S$ & 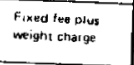 & 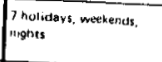 & $\overline{\mathrm{N} / \mathrm{S}}$ & $\mathrm{N} / \mathrm{S}$ & & & No & & & All ibatiliness & No & $N / S$ & Wosanerstifeld, CT 06109 \\
\hline 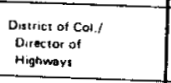 & 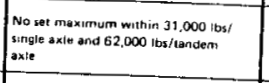 & $\begin{array}{l}\text { Annual } \\
\text { Single trio }\end{array}$ & $\begin{array}{c}\text { reat } \\
\mathrm{N} / \mathrm{s}\end{array}$ & Fixed tee & Soscial occassions & N/S & N/S & & Proment & No $_{\text {No }}$ & 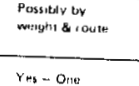 & N/S & TC reguiventents & No & $N / S$ & 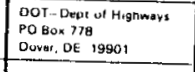 \\
\hline 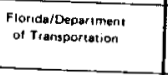 & 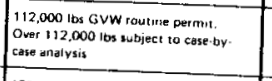 & $\begin{array}{l}\text { Bianker } \\
\text { Single trip }\end{array}$ & $\begin{array}{l}36 \text { monath } \\
12 \text { manth } \\
5 \text { duars }\end{array}$ & $\begin{array}{l}\text { Fixed tee bv } \\
\text { weightc coutegurv }\end{array}$ & 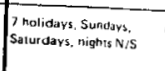 & N/S & N/S & & six:sillumed & No & 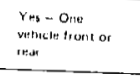 & $\begin{array}{l}\text { Pertruten } \\
\text { vethuile }\end{array}$ & 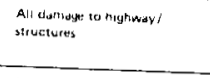 & No & Nis & 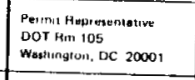 \\
\hline 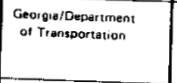 & 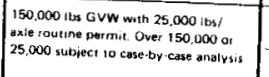 & Single trip & N/S & N/S & $\begin{array}{l}\text { 3holiders, Sunvarss } \\
\text { rights }\end{array}$ & fog, snow, lice & N/S & & 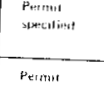 & No & Na & $N / S$ & $\begin{array}{l}\text { All domasese to lighnwayt } \\
\text { stuclurese }\end{array}$ & No & $N / S$ & 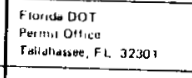 \\
\hline 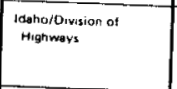 & 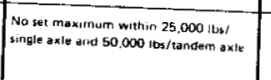 & $\begin{array}{l}\text { Atrinual } \\
\text { Singse trip }\end{array}$ & $\begin{array}{c}\text { Yeat } \\
\text { w,s }\end{array}$ & 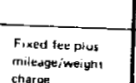 & 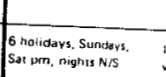 & Ict, stiow, tost, bad & & & 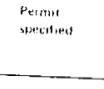 & No. & No & N/S & 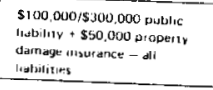 & No & N/S & 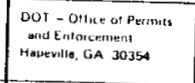 \\
\hline 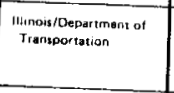 & 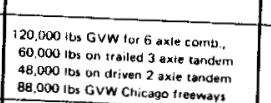 & Single thip & N/S & 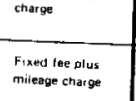 & $\mid$ & 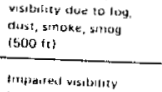 & & 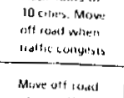 & 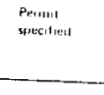 & No & No & 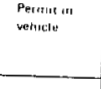 & 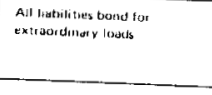 & 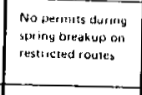 & 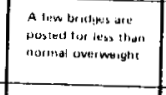 & 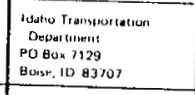 \\
\hline $\begin{array}{l}\text { Intiana/Department: of } \\
\text { Highwers }\end{array}$ & 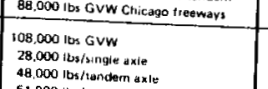 & Singlet trip & $N / S$ & $N / S$ & 6 holidars, weekends. & 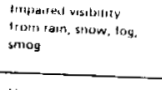 & $\begin{array}{l}5 \text { mon over } \\
\text { min sperd }\end{array}$ & 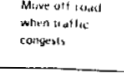 & 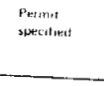 & no & N/S & 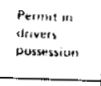 & Ali responisulutitites & No & 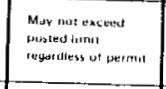 & 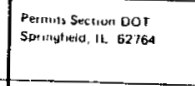 \\
\hline 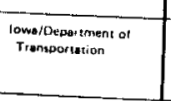 & 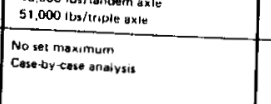 & $\begin{array}{l}\text { Annual } \\
\text { Single trop }\end{array}$ & $\begin{array}{l}\text { Vear } \\
\text { Nis }\end{array}$ & Fixod lee & 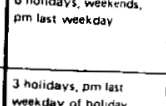 & 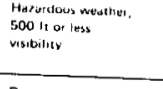 & $N / S$ & 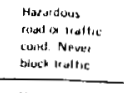 & 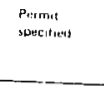 & 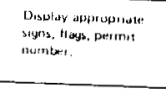 & No & 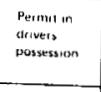 & 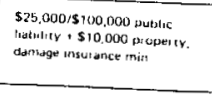 & No & $N / S$ & 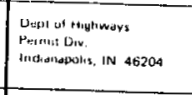 \\
\hline 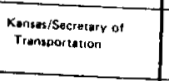 & 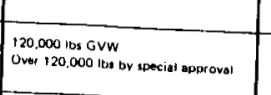 & $\begin{array}{l}\text { Conlumous } \\
\text { Singte trip }\end{array}$ & $\begin{array}{l}\text { varisble } \\
\text { N/s }\end{array}$ & Fiveu fae & 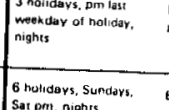 & $\begin{array}{l}\text { Reassinatle } \\
\text { prectautions }\end{array}$ & $45 \mathrm{mph}$ & 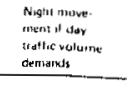 & $\begin{array}{l}\text { Perrmit } \\
\text { sprutheu }\end{array}$ & No & 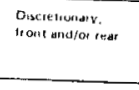 & 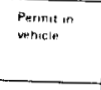 & 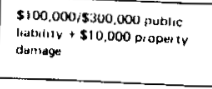 & No & $\begin{array}{l}\text { Mar nol exceed } \\
\text { posied limul }\end{array}$ & 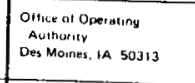 \\
\hline 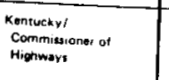 & 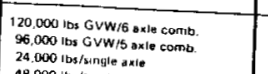 & $\begin{array}{l}\text { Extended } \\
\text { Single trip }\end{array}$ & $\underset{\text { Variable }}{\text { Nis }}$ & Fixes les & 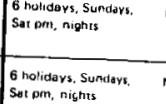 & Bad meanthor & N/S & $\begin{array}{l}\text { Bad nowd } \\
\text { cantiducuns }\end{array}$ & $\begin{array}{l}\text { Perum } \\
\text { serectitud }\end{array}$ & No & No & 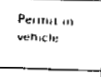 & 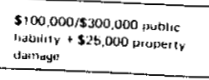 & No & $\mathrm{N} / \mathrm{S}$ & 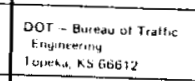 \\
\hline 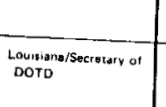 & 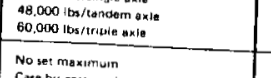 & & & & 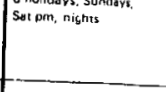 & $\mathrm{N} / \mathrm{s}$ & $\mathrm{N} / \mathrm{s}$ & N/S & 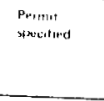 & $\mathrm{N}: 3$ & No & $\begin{array}{l}\text { Perrimutin } \\
\text { vethicle }\end{array}$ & 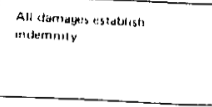 & No & N/S & 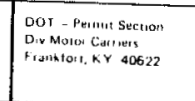 \\
\hline e: & 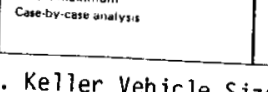 & Single trip & N:S & 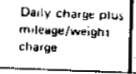 & 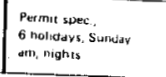 & Inclement weather & 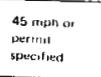 & Nis & 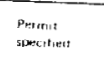 & No & 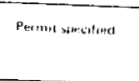 & 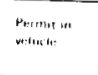 & 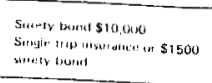 & No & Nis & 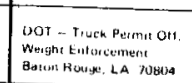 \\
\hline
\end{tabular}


APPENDIX A

STATE PERMIT REQUIREMENTS FOR OVERWEIGHT VEHICLES

\begin{tabular}{|c|c|c|c|c|c|c|c|c|c|c|c|c|c|c|c|c|}
\hline Sterer/Agoncer & 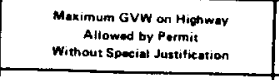 & Tyese & $\begin{array}{c}\text { Paremion } \\
\text { Durstion }\end{array}$ & Fos & Time & $\begin{array}{l}\text { Travel Aestiri } \\
\text { westher }\end{array}$ & ctions spest & Other & Routing & Markingerem & $\begin{array}{l}\text { ions } \\
\text { Exorns } \\
\end{array}$ & Avelabobitiv & 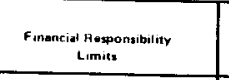 & Fross Lows & 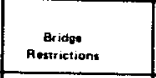 & Permit Oticke \\
\hline $\begin{array}{l}\text { Mane//Oepartmenti of } \\
\text { Treassportation }\end{array}$ & 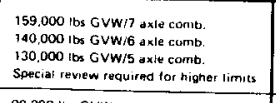 & Single trip & N/S & $\begin{array}{l}\text { Fi ixed fere pus } \\
\text { weight charge }\end{array}$ & 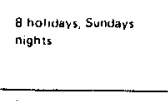 & $N / S$ & N/S & N/S & 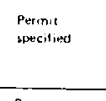 & No & No & $\begin{array}{l}\text { Permul in } \\
\text { vethicle }\end{array}$ & 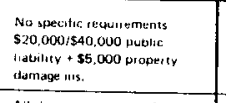 & 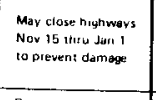 & N/S & 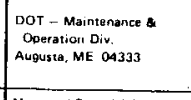 \\
\hline $\begin{array}{l}\text { Marylanditignowar } \\
\text { Aumimistration }\end{array}$ & 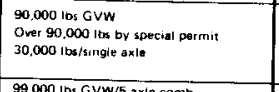 & $\begin{array}{l}\text { Blanke1 } \\
\text { Single ling } \\
\end{array}$ & $\begin{array}{l}\text { Annual } \\
30 \text { dav }\end{array}$ & 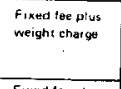 & 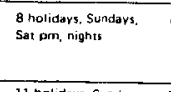 & N/S & $\begin{array}{l}35 \text { mpn for } \\
\text { GVw } 90,000 \\
\text { las } \\
\end{array}$ & $N / S$ & $\begin{array}{l}\text { Permit } \\
\text { spectified }\end{array}$ & $\mathrm{No}$ & 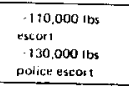 & $\mathrm{N} / \mathrm{S}$ & 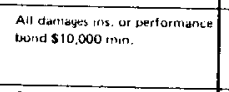 & 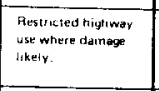 & N/S & 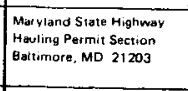 \\
\hline 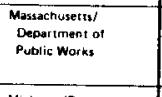 & 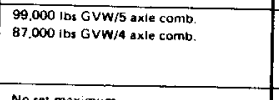 & \begin{tabular}{|l|l|} 
Singiete tip \\
\end{tabular} & $\mathrm{N} / \mathrm{s}$ & $\begin{array}{l}\text { Fixed ter plut } \\
\text { weiphe charge }\end{array}$ & 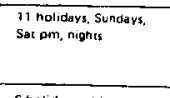 & N/S & $\mathrm{N/S}$ & $\mathrm{N} / \mathrm{s}$ & 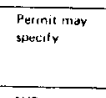 & 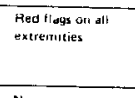 & No & $N / S$ & 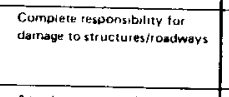 & No & 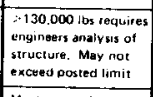 & 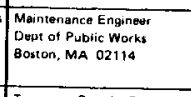 \\
\hline 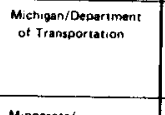 & \begin{tabular}{|l} 
No set maximum \\
cosety cose analysit
\end{tabular} & \begin{tabular}{|l} 
Extranded \\
Simgle trip
\end{tabular} & $\begin{array}{l}N / S \\
\leqslant S \text { days }\end{array}$ & Fixeat toe & 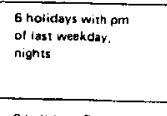 & $N / S$ & $\begin{array}{l}35 \text { mph during } \\
\text { serning restrictions }\end{array}$ & $N / S$ & $\bar{N} / \mathrm{s}$ & No & No & $\begin{array}{l}\text { Pertrite } \\
\text { venicte }\end{array}$ & 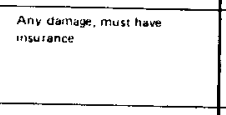 & 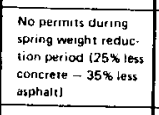 & 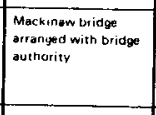 & 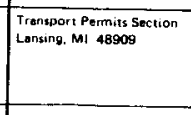 \\
\hline 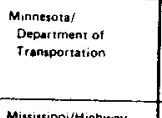 & 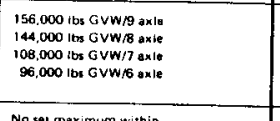 & \begin{tabular}{|l|} 
Arnusal \\
Jon \\
Singito urip
\end{tabular} & $\begin{array}{l}1 \text { vear } \\
\text { semonths } \\
\text { Nis }\end{array}$ & Fixed teos & 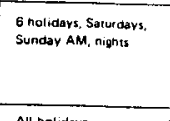 & Advers wesilher & $N / S$ & 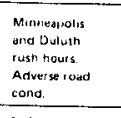 & $N / S$ & No & No & $\begin{array}{l}\text { Peermut in } \\
\text { venicle }\end{array}$ & 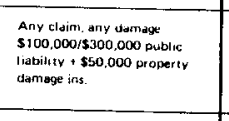 & 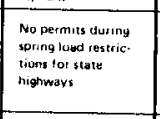 & N/S & $\begin{array}{l}\text { Mrin doot } \\
\text { Transportation Blida } \\
\text { St. Paul, MN } 55155\end{array}$ \\
\hline $\begin{array}{l}\text { Misisisippi/Hignway } \\
\text { Dopest Iment }\end{array}$ & 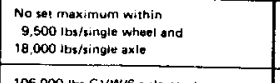 & \begin{tabular}{|l}
$\begin{array}{l}\text { Bianket } \\
\text { Sninget rip }\end{array}$ \\
\end{tabular} & $\begin{array}{l}56 \text { months } \\
<5 \text { a dars }\end{array}$ & 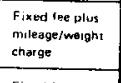 & \begin{tabular}{|l|} 
All hol idarss, \\
Sundays, sat pm, \\
nighote.
\end{tabular} & Special weather & $\begin{array}{l}50 \text { minh hignoways } \\
10 \text { mph brutuges }\end{array}$ & N/S & $\begin{array}{l}\substack{\text { Perrimit } \\
\text { speciled }} \\
\text { sed }\end{array}$ & Nis & $N / 5$ & 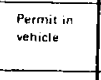 & 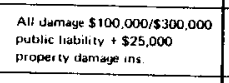 & No & 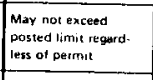 & 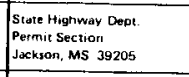 \\
\hline 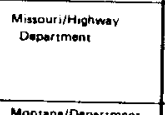 & 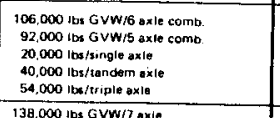 & 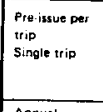 & 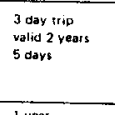 & Fixed ter & 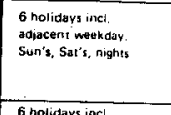 & Vistointy $<$ :500 th & $\mathrm{N} / \mathrm{s}$ & 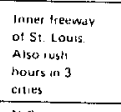 & $\begin{array}{l}\text { Peermit mar } \\
\text { speciiv }\end{array}$ & No & No & $\begin{array}{l}\text { Peennil in } \\
\text { venicle }\end{array}$ & 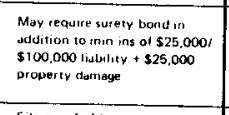 & Decasionally used & $N / S$ & 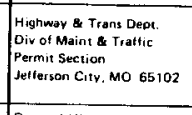 \\
\hline 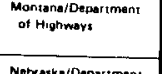 & 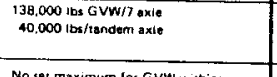 & \begin{tabular}{|l} 
Annual \\
Singte trip
\end{tabular} & $\begin{array}{l}\text { Tyear } \\
\text { Verizaio }\end{array}$ & 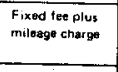 & 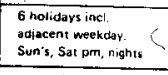 & & $\mathrm{N} / \mathrm{s}$ & $N / S$ & N/S & No & No & $\mathrm{N} / \mathrm{s}$ & File proot of inssurance & \begin{tabular}{|l|} 
Yegs \\
Special consididerations
\end{tabular} & N/S & 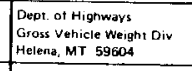 \\
\hline 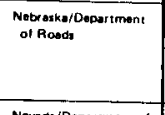 & 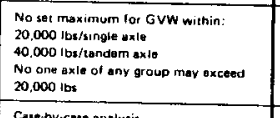 & \begin{tabular}{|l|} 
Conntinuous \\
Singlet tip
\end{tabular} & $\underset{N / S}{66 \text { month }}$ & Fixest teet & $\begin{array}{l}7 \text { holidós, Sun's, } \\
\text { Sart's, nights }\end{array}$ & Marardous wesiher & $N / S$ & 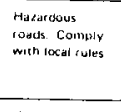 & $N / S$ & No & No & $\mathrm{N} / \mathrm{s}$ & 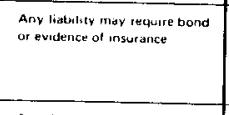 & $\begin{array}{l}\text { At departments } \\
\text { discietion }\end{array}$ & 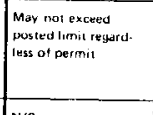 & 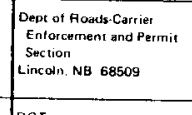 \\
\hline 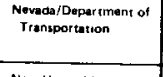 & Cars by cane sinatysit & \begin{tabular}{|l} 
Annuat \\
Singlo wis
\end{tabular} & $\begin{array}{l}\text { Year } \\
5 \text { work dary }\end{array}$ & Fixed tree & \begin{tabular}{|l|}
$\begin{array}{l}\text { No restrictichans if anly } \\
\text { overemeight }\end{array}$ \\
\end{tabular} & Hazardous weasther & $55 \mathrm{mph}$ & $\begin{array}{l}\text { Hazaltivus } \\
\text { loars }\end{array}$ & $N / S$ & No & No & 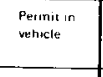 & 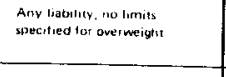 & $\begin{array}{l}\text { Rewere essticticuns } \\
\text { fevsed annualiy }\end{array}$ & $\mathrm{N} / \mathrm{S}$ & 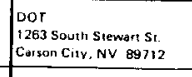 \\
\hline New Hampaniro & 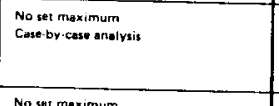 & \begin{tabular}{|l|} 
Single rip \\
\end{tabular} & 5 davs & $\begin{array}{l}\text { Fixed tee pius } \\
\text { weight charges }\end{array}$ & 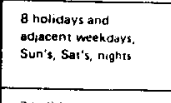 & Incletenent weather & 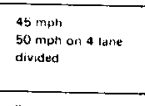 & $\begin{array}{l}\text { Nonte lor } \\
\text { overweignt }\end{array}$ & 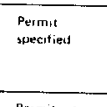 & No & No & $\begin{array}{l}\text { Putrum in } \\
\text { venticte }\end{array}$ & All responsinutitites & 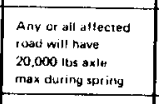 & 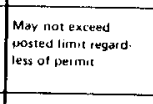 & 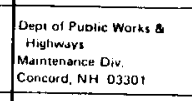 \\
\hline 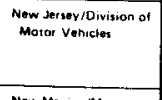 & 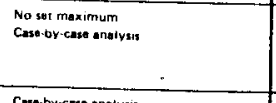 & Single inip & 3 days & $\begin{array}{l}\text { Fixed tee plus } \\
\text { werght craseger }\end{array}$ & 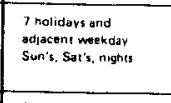 & $N / S$ & 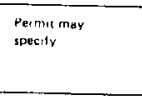 & $\begin{array}{l}\text { Novi al lowas on } \\
\text { toll rods }\end{array}$ & $\begin{array}{l}\text { Permit miay } \\
\text { swecity }\end{array}$ & No & No & $N / S$ & 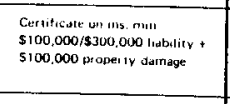 & No & N/S & 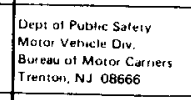 \\
\hline 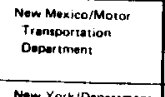 & Costoby-case onolyzis & \begin{tabular}{|l|l|}
$\begin{array}{l}\text { Mutritiole } \\
\text { Single trip }\end{array}$ \\
\end{tabular} & $\underset{N / S}{N / S}$ & Fixed tee & 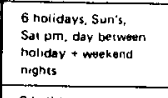 & inclemereri weather & $\mathrm{N} / \mathrm{s}$ & & 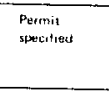 & No & 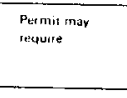 & 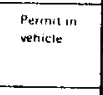 & 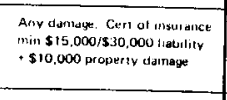 & 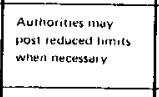 & $N / s$ & 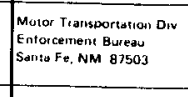 \\
\hline 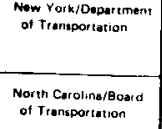 & 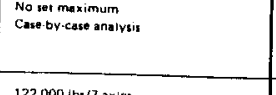 & 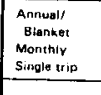 & $\begin{array}{l}\text { Year } \\
30 \text { days } \\
8 \text { days } \\
\end{array}$ & Fixed toe & 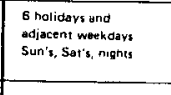 & $N / S$ & $N / S$ & $\begin{array}{l}\text { Thumuon that } \\
\text { special tees. }\end{array}$ & $\begin{array}{c}\text { Pesmmit mar } \\
\text { spectivy }\end{array}$ & No & No & $\begin{array}{l}\text { Permatian } \\
\text { venthele }\end{array}$ & 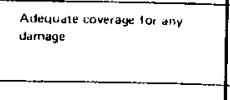 & No & $N / S$ & 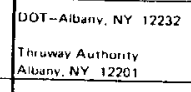 \\
\hline 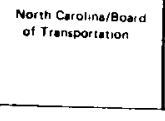 & 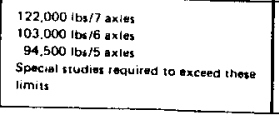 & $\begin{array}{l}\text { Annual } \\
\text { Single trip }\end{array}$ & rear & Fixeod tee & 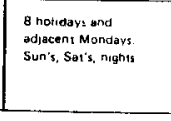 & $\mathrm{N} / \mathrm{S}$ & 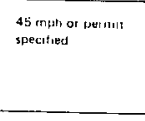 & - & $\mathrm{N} / \mathrm{S}$ & No & No & $\begin{array}{l}\text { Permmin } \\
\text { velluctr }\end{array}$ & 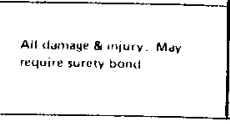 & No & N/S & 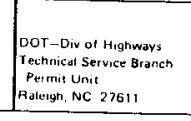 \\
\hline
\end{tabular}


APPENDIX A

\begin{tabular}{|c|c|c|c|c|c|c|c|c|c|c|c|c|c|c|c|c|}
\hline Sutota/Apency & \multirow{2}{*}{ 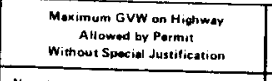 } & \multirow{2}{*}{ Trpes } & \multirow{2}{*}{$\begin{array}{c}\text { Permits } \\
\text { Duration } \\
\end{array}$} & \multirow{2}{*}{ fout } & \multirow[b]{2}{*}{ Time } & \multirow{2}{*}{\multicolumn{2}{|c|}{$\begin{array}{c}\text { Travor Aessticitions } \\
\text { westher }\end{array}$}} & & & & & & & & & \\
\hline 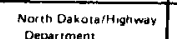 & & & & & & & & Oaterer & Routing & \multicolumn{2}{|c|}{ 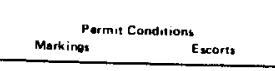 } & Avatubatility & $\begin{array}{c}\text { I Inamciat Rasponstbility } \\
\text { Limits }\end{array}$ & Frout tows & $\begin{array}{c}\text { Brodag } \\
\text { Aostinciions }\end{array}$ & Permin office \\
\hline Devastrment & 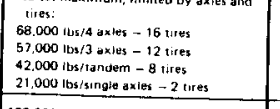 & Single tipe & & Fixed lee & 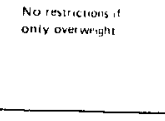 & Adverse weather & $\begin{array}{l}55 \text { moph concuetere } \\
35 \text { mph astronale }\end{array}$ & & $N / S$ & No & No & $\mathrm{N} / \mathrm{s}$ & Muss tile evidence of insurancer & 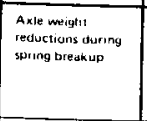 & $N / S$ & 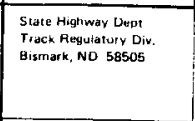 \\
\hline 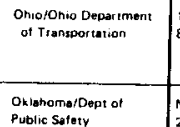 & 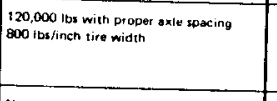 & $\begin{array}{l}\text { Inactive } \\
\text { Cantivung } \\
\text { Active }\end{array}$ & 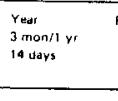 & Fixed tee & 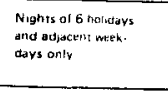 & N/S & $\begin{array}{l}\text { Permul specifited } \\
\text { maximusm }\end{array}$ & 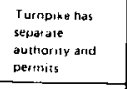 & 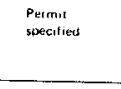 & 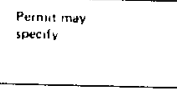 & $\begin{array}{l}\text { Pernu may } \\
\text { Spectity }\end{array}$ & $\begin{array}{l}\text { Perrnit ar } \\
\text { vehncle }\end{array}$ & 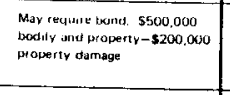 & No & 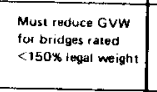 & 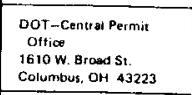 \\
\hline 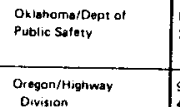 & 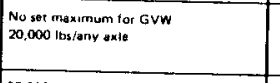 & $\begin{array}{l}\text { Single erip } \\
\text { onivy }\end{array}$ & $\mathrm{N} / \mathrm{s}$ & $\begin{array}{l}\text { Fixes tee plus } \\
\text { weigni chersose }\end{array}$ & $\begin{array}{l}\text { No restrictions on } \\
\text { overwetight }\end{array}$ & Adverse wearther & $\begin{array}{l}\text { ind mph on } \\
\text { interstares }\end{array}$ & 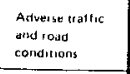 & $\begin{array}{l}\text { Petrmut } \\
\text { specitifed } \\
\end{array}$ & No & No & $\begin{array}{l}\text { Peermiti in } \\
\text { veluctele }\end{array}$ & 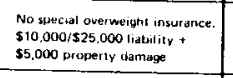 & No & N/S & 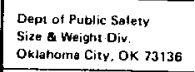 \\
\hline $\begin{array}{l}\text { Oelogon/Highnay } \\
\text { Owistion }\end{array}$ & 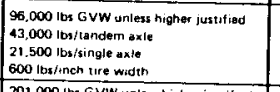 & \begin{tabular}{|l} 
Continuing \\
Opeastion \\
Singote unp
\end{tabular} & 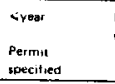 & 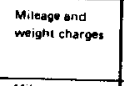 & $\mathrm{N} / \mathrm{s}$ & Adverse weriner & N/S & Adverse road & $\begin{array}{l}\text { Perernit } \\
\text { secalliod }\end{array}$ & No & No & $N / S$ & 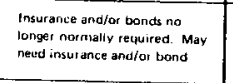 & No & 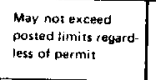 & 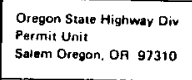 \\
\hline 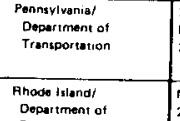 & 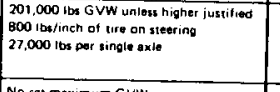 & Singlet inip & 5 deves & 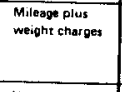 & 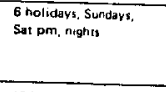 & Adverse weather & $\mathrm{N} / \mathrm{s}$ & Adversest rood & $N / S$ & No & 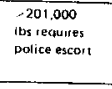 & $\begin{array}{l}\text { Peeturit in } \\
\text { vencice }\end{array}$ & 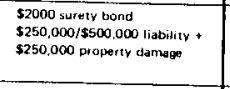 & 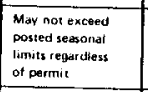 & $\mathrm{N} / \mathrm{s}$ & \begin{tabular}{|l|} 
DOT-Petrmit Section \\
Transportation S Satetr \\
Bldy \\
Matrisburg, PA 17120 \\
\end{tabular} \\
\hline 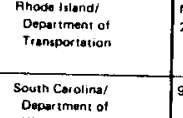 & 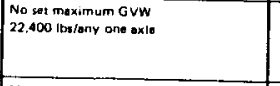 & $\begin{array}{l}\text { Continuour } \\
\text { single trip }\end{array}$ & $\begin{array}{ll}N / S \\
N / S\end{array}$ & Nane & 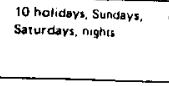 & $N / S$ & N/S & - & 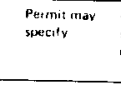 & 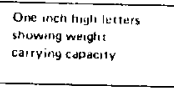 & No & $N / S$ & Normat insurance coveragege & 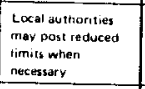 & $\mathrm{N} / \mathrm{s}$ & 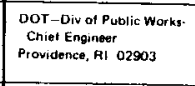 \\
\hline 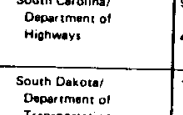 & 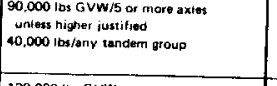 & $\begin{array}{l}\text { Singlie/open } \\
\text { send } \\
\text { single tip }\end{array}$ & $\begin{array}{l}\text { Variable } \\
2 \text { meeks }\end{array}$ & Fixeos teo & $\begin{array}{l}5 \text { holidars, weekends. } \\
\text { nights }\end{array}$ & $\mathrm{N} / \mathrm{s}$ & $\mathrm{N} / \mathrm{s}$ & 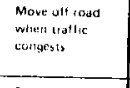 & $\begin{array}{l}\text { Persmut } \\
\text { sseculted }\end{array}$ & No & No & 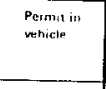 & All darmases $\$ 500$ or mort & No & $N / S$ & 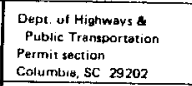 \\
\hline $\begin{array}{l}\text { Depasermentrot of } \\
\text { Transportition }\end{array}$ & 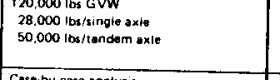 & \begin{tabular}{|l} 
Annusi \\
6 month \\
Singter trip
\end{tabular} & 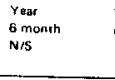 & $\begin{array}{l}\text { Meignt plut } \\
\text { miteage charget }\end{array}$ & $\begin{array}{l}6 \text { holidays, Surdars. } \\
\text { Sal am, nights }\end{array}$ & Hatad fous weather & N/S & 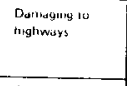 & 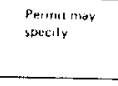 & No & No & $\begin{array}{l}\text { Permini an } \\
\text { vethicie }\end{array}$ & 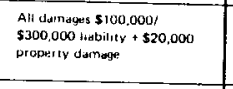 & \begin{tabular}{|l|}
$75 \%$ of load on \\
concrete, $65 \%$ of \\
load on asphalt \\
during buringy \\
\end{tabular} & N/S & \begin{tabular}{|l|} 
DOT-Operation Support \\
Progiam \\
Pierre. SO 57501
\end{tabular} \\
\hline 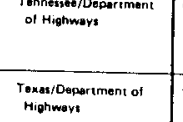 & Cosen by cose anatysis & $\begin{array}{l}\text { Annual } \\
\text { Singie trip } \\
\text { specified }\end{array}$ & $\begin{array}{c}\text { Year } \\
\text { Nos }\end{array}$ & $\begin{array}{l}\text { Weight phus } \\
\text { mulugage charge }\end{array}$ & 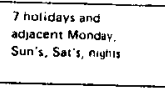 & $\begin{array}{l}\text { Unsite surtacts. } \\
\text { snow, ice, elc }\end{array}$ & $N / S$ & 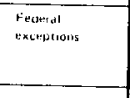 & 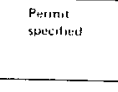 & No & No & $\mathrm{N} / \mathrm{s}$ & 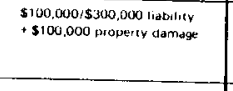 & No & $N / S$ & 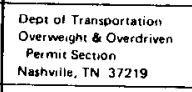 \\
\hline 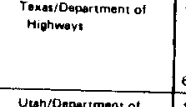 & 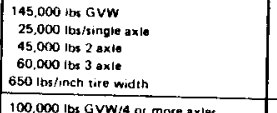 & Singite erip & N/S & Fixed tee & 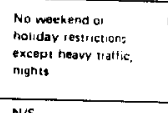 & Poor usitumity & $N / S$ & $\begin{array}{l}\text { Slav ull } \\
\text { stroutleys witen } \\
\text { solt }\end{array}$ & Perenum mav & $\mathrm{Na}$ & No & 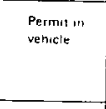 & $\begin{array}{l}\text { Surery Lond tor uossitle } \\
\text { darlage }\end{array}$ & No & Nis & 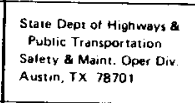 \\
\hline 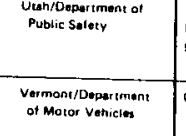 & 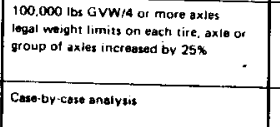 & 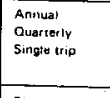 & $\begin{array}{l}\text { rear } \\
3 \text { monums } \\
4 \text { d deys }\end{array}$ & $\begin{array}{l}\text { Ditterential } \\
\text { migrinc charges }\end{array}$ & $\mathrm{N} / \mathrm{s}$ & 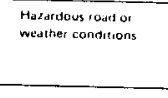 & 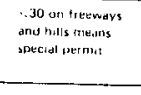 & 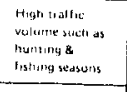 & $\begin{array}{l}\text { Peermut nay } \\
\text { sixculy }\end{array}$ & No & No & $\begin{array}{l}\text { Peimut in } \\
\text { vencicie }\end{array}$ & 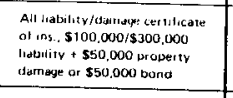 & No & N/S & 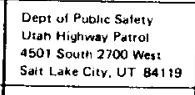 \\
\hline 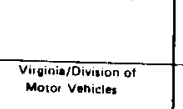 & & $\begin{array}{l}\text { Biannet } \\
\text { Single trip }\end{array}$ & $\begin{array}{l}\text { Yoar } \\
10 \text { caps }\end{array}$ & Fixed tee & 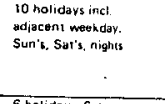 & $\begin{array}{l}\text { Adverss hightimar } \\
\text { conoditions }\end{array}$ & 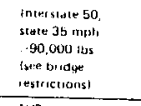 & $\begin{array}{l}\text { Lecal wergen' } \\
\text { regularions }\end{array}$ & $\begin{array}{l}\text { Peurnit: } \\
\text { spercilters }\end{array}$ & No & No & $\begin{array}{l}\text { Permutin } \\
\text { venhicle }\end{array}$ & 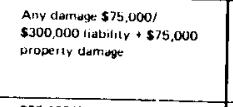 & 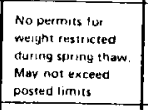 & 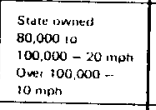 & 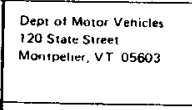 \\
\hline 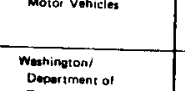 & 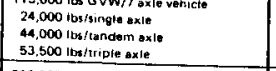 & $\begin{array}{l}\text { Batannet } \\
\text { Singate crip }\end{array}$ & $\begin{array}{l}\text { Year } \\
2 \text { works }\end{array}$ & $\begin{array}{l}\text { Weight lils } \\
\text { cilesge cherge }\end{array}$ & 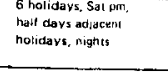 & 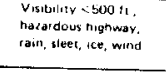 & $\mathrm{N} / \mathrm{s}$ & & $\mathrm{N} / \mathrm{s}$ & No & No & $\mathrm{N} / \mathrm{s}$ & 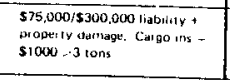 & No & $N / S$ & 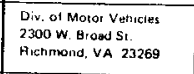 \\
\hline 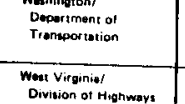 & 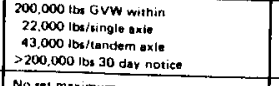 & $\begin{array}{l}\text { Annuart } \\
\text { coninuuous } \\
\text { Singte tripi }\end{array}$ & $\begin{array}{l}\text { Year or } \\
\text { moref } \\
\text { Nols }\end{array}$ & 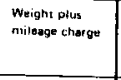 & 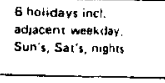 & 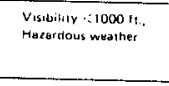 & $\begin{array}{l}\text { Perinil mav } \\
\text { spectily }\end{array}$ & $\begin{array}{l}\text { Aush hous in } \\
\text { 3ctives }\end{array}$ & $\begin{array}{l}\text { Perinum } \\
\text { spectitued }\end{array}$ & No & No & $N / S$ & 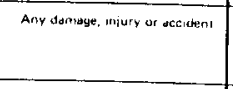 & 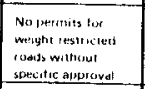 & N/S & 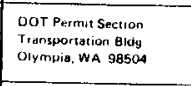 \\
\hline Divivion of thighnarys & 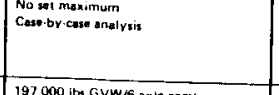 & Singlet trip & 3 davs & $\begin{array}{l}\text { Weighn pius } \\
\text { milezge chargo }\end{array}$ & 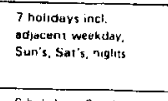 & $N / 5$ & Nis & & $\begin{array}{l}\text { Permut } \\
\text { survectitured }\end{array}$ & No & No & 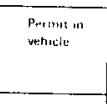 & 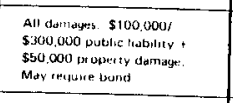 & 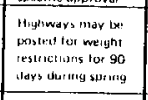 & N/S & 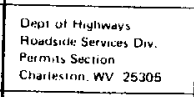 \\
\hline & 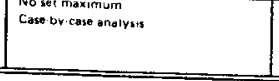 & $\begin{array}{l}\text { Extended } \\
\text { Siryle orip }\end{array}$ & $\begin{array}{l}\text { 8y mortith } \\
\text { so to yeat } \\
4 \text { dary }\end{array}$ & 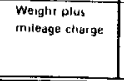 & 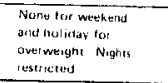 & & 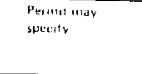 & & 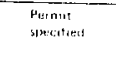 & 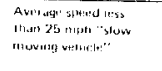 & $\mathrm{Nin}$ & 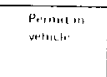 & 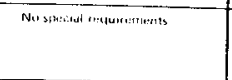 & \begin{tabular}{|l|l} 
No \\
\end{tabular} & 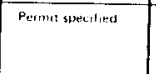 & 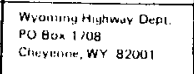 \\
\hline
\end{tabular}




\section{APPENDIX A \\ PERMIT REQUIREMENTS FOR TOLL ROADS}

\begin{tabular}{|c|c|c|c|c|}
\hline $\begin{array}{l}\text { Facility } \\
\text { Authority }\end{array}$ & $\begin{array}{l}\quad \text { Maximum } \\
\text { Gross Vehicle } \\
\text { Weight Without } \\
\text { Permit (Ibs.) }\end{array}$ & $\begin{array}{c}\text { Maximum } \\
\text { Allowable } \\
\text { GVW With } \\
\text { Permit (lbs.) }\end{array}$ & $\begin{array}{l}\text { Type } \\
\text { Permit }\end{array}$ & $\begin{array}{c}\text { Time } \\
\text { Restrictions }\end{array}$ \\
\hline
\end{tabular}

\begin{tabular}{|c|c|c|c|c|c|}
\hline & $\begin{array}{l}\text { Connecticut } \\
\text { State Highway } \\
\text { Department }\end{array}$ & 73,000 & 120,000 & Single Trip & $\begin{array}{l}\text { Nights/ } \\
\text { Weekends }\end{array}$ \\
\hline 2. & $\begin{array}{l}\text { Delaware } \\
\text { State Highway } \\
\text { Department }\end{array}$ & 73,280 & UnTimited & Single Trip & $\begin{array}{l}\text { Nights/ } \\
\text { Weekends }\end{array}$ \\
\hline 3. & $\begin{array}{l}\text { Florida } \\
\text { Department of } \\
\text { Transportation }\end{array}$ & $N / S$ & None & None & $\mathrm{N} / \mathrm{S}$ \\
\hline 4. & $\begin{array}{l}\text { Illinois State } \\
\text { Toll Highway } \\
\text { Authority }\end{array}$ & $\begin{array}{l}\text { Based on } \\
\text { axle weights }\end{array}$ & $\begin{array}{l}\text { Based on } \\
\text { axle weights }\end{array}$ & Single Trip & $\begin{array}{l}\text { Nights/ } \\
\text { Weekends }\end{array}$ \\
\hline 5. & $\begin{array}{l}\text { Indiana Toll } \\
\text { Road Commission }\end{array}$ & 90,000 & 127,400 & Single Trip & $\begin{array}{l}\text { Nights/ } \\
\text { Weekends }\end{array}$ \\
\hline 6. & $\begin{array}{l}\text { Kansas Turnpike } \\
\text { Authority }\end{array}$ & $N / S$ & $N / S$ & Single Trip & $\begin{array}{l}\text { Nights/ } \\
\text { Weekends }\end{array}$ \\
\hline 7. & $\begin{array}{l}\text { Maryland State } \\
\text { Roads Commission }\end{array}$ & 70,000 & 90,000 & Single Trip & $\begin{array}{l}\text { Nights/ } \\
\text { Weekends }\end{array}$ \\
\hline 8. & $\begin{array}{l}\text { Massachusetts } \\
\text { Turnpike } \\
\text { Authority }\end{array}$ & 60,000 & 127,000 & Single Trip & Weekends \\
\hline 9. & $\begin{array}{l}\text { New Jersey } \\
\text { Expressway } \\
\text { Authority }\end{array}$ & 73,500 & Unlimited & Single Trip & $\begin{array}{l}\text { Nights/ } \\
\text { Weekends }\end{array}$ \\
\hline 10. & $\begin{array}{l}\text { New Jersey } \\
\text { Highway Author- } \\
\text { ity (Garden } \\
\text { State Parkway) }\end{array}$ & 73,280 & 140,000 & Single Trip & $\begin{array}{l}\text { Nights/ } \\
\text { Weekends }\end{array}$ \\
\hline 1. & $\begin{array}{l}\text { New Jersey } \\
\text { Turnpike } \\
\text { Authority }\end{array}$ & $\mathrm{N} / \mathrm{S}$ & $N / S$ & $N / S$ & $N / S$ \\
\hline 12. & $\begin{array}{l}\text { New York State } \\
\text { Thruway } \\
\text { Authority }\end{array}$ & 71,000 & 105,000 & Single Trip & Weekends \\
\hline 3. & $\begin{array}{l}\text { Ok lahoma Turn- } \\
\text { pike Authority }\end{array}$ & 73,280 & $\begin{array}{l}18,000 / \\
\text { axle }\end{array}$ & Single Trip & $\begin{array}{l}\text { Nights/ } \\
\text { Weekends }\end{array}$ \\
\hline 4. & $\begin{array}{l}\text { Pennsylvania } \\
\text { Turnpike } \\
\text { Commission }\end{array}$ & 100,000 & Unlimited & Single Trip & $\begin{array}{l}\text { Nights/ } \\
\text { Weekends }\end{array}$ \\
\hline 5. & $\begin{array}{l}\text { Texas Turnpike } \\
\text { Authority }\end{array}$ & 72,000 & None & Single Trip & $\begin{array}{l}\text { Nights/ } \\
\text { Weekends }\end{array}$ \\
\hline 6. & $\begin{array}{l}\text { West Virginia } \\
\text { Turnpike } \\
\text { Commission }\end{array}$ & Unlimited & Unlimited & Single Trip & Weekends \\
\hline
\end{tabular}


APPENDIX B

APPLICATION OF BRIDGE GROSS WEIGHT FORMULA 


\section{APPENDIX B \\ APPLICATION OF BRIDGE GROSS WEIGHT FORMULA}

Three questions are addressed by this pamphlet with regard to the Bridge Formula. What is it? Why is it necessary? How is it used?

\section{WHAT IS IT?}

The bridge gross weight formula provides a standard to control the spacing of truck axles on vehicles that use highway bridges.

$W=$ the maximum weight in pounds that can be carried on a group of two or more axles to the nearest 500 pounds.

$\mathbf{L}=$ spacing in feet between the outer axles of any two or more consecutive axles.

$\mathrm{N}=$ number of axles being considered.

\section{WHY IS THE FORMULA NECESSARY?}

An individual set of bridge design computations cannot be completed for every type truck that may use the highways; to do this for every type truck would take years. Consequently, the Nation's bridge engineers have selected what is referenced as a design vehicle. This one vehicle is considered to be representative of all vehicles that will use a bridge during the $\mathbf{4 0}$ to 50-year life of the structure. A more common description would be to call the design truck an umbrella loading, as shown below:

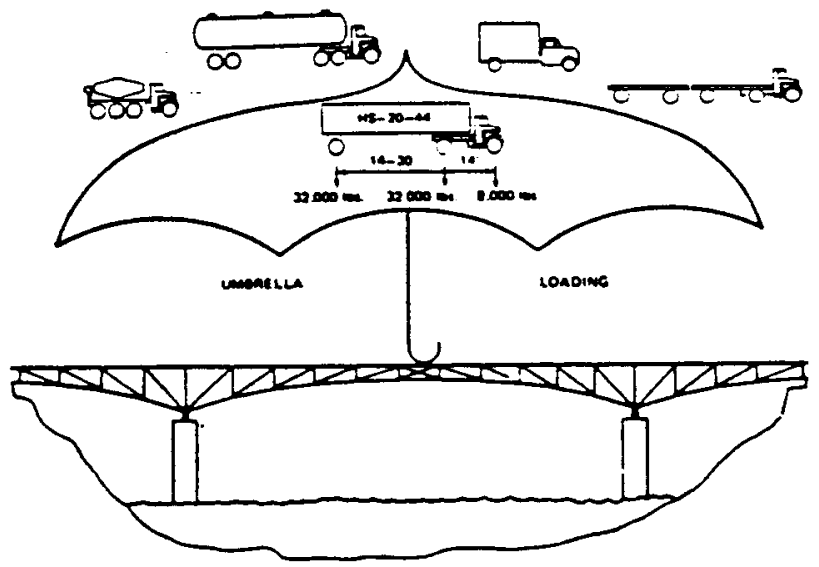

Figure 1

Assuming that the umbrella loading illustrated above creates the most severe situation as a bridge is designed, bridge members are built strong enough to handle the umbrella loading and in effect the bridge is protected from being overstressed by any future truck that may use the structure.

The umbrella loading described in Figure 1, which is used for Interstate highway bridge design, was adopted in 1944 with specific axie weights and spacing as shown. For years enforcement officials have worked to check truck weights to keep the axle loads and gross loads within legal limits. With the passage of the Federal-aid Amendments of 1974, the States aiso had to become concerned with the spacing of axles when enforcing weight laws on the Interstate System.

The axle spacing is equally as important in design of the bridges as the axle weights. This is illustrated by what happens when a person tries to walk across ice that is hardly thick enough to support his/ her weight; the person is likely to fall through. If that person stretched out prone on the same ice and scooted across, it is unlikely that he/she would break through. This is true because the load, or weight, is spread over a larger area in the latter situation. A similar comparison can be made between trucks crossing a bridge:

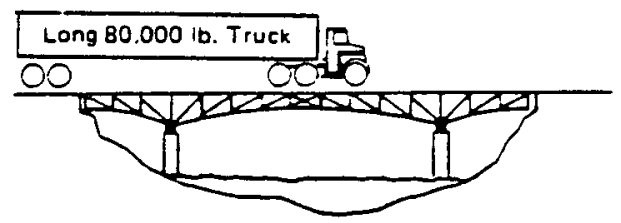

(A)

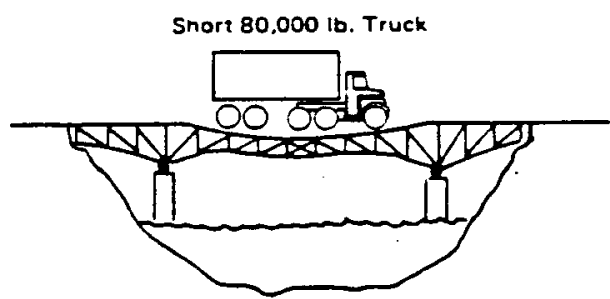

(B)

Figure 2

In view (A) of Figure 2, the stress on bridge members as the long truck rolls across is much less than that caused by the shor truck in view (B), even though the trucks have the same total weight and individual axie weights. One can see that an extremely long truck would have its load spread out like the 
person scooting across the ice. Whereas, the short truck is similar to a person standing up on ice with the total load placed in a limited area.

After the umbrella loading was adopted in 1944. many Interstate bridges were built during the late 1950 s and 1960s. Simultaneously, bigger and heavier trucks were being placed into use than had been anticipated in 1944. It was not practical to consider rebuilding all bridges for the newer trucks that either had been or could be placed on the road. The logical and economical action not only was to control the gross and axle weights of trucks but also to control the spacing of the axles. The U.S. Congress concurred with this approach. In 1974, when the higher axie and gross weight limits were adopied for the Interstate System $(20,000$ pounds-single axle, 34,000 poundstandem axle, 80,000 pounds-gross), the Bridge Formula was written into Section 127 of the United States Code, Title 23. The Bridge Formula assures that allowable weight of heavy trucks is correlated with the spacing of axles to prevent overstressing of highway bridges; in other words, preventing an effect similar to a person standing erect on thin ice. The overstressing can occur even when the gross weight and each individual axle weight of a truck are within lawful limits.

\section{HOW IS THE FORMULA USED?}

Some definitions are needed before completing example applications of the Bridge Formula.

- Gross Weight*-the weight of a vehicle and/or vehicle combination without load plus the weight of any load thereon. The Federal gross weight limit on the Interstate is 80,000 pounds.

- Single Axle Weight -the total weight transmitted by all wheels whose centers may be included between two parallel transverse verical planes 40 inches apart, extending across the full width of the vehicle. The Federal single axle weight limit on the Interstate is 20,000 pounds.

- Tandem Axle Weight* - the total weight transmitted to the road by two or more consecutive axles whose centers may be included between parallel verical planes spaced more than 40 inches and not more than 96 inches apart, extending across the full width of the vehicie. The Federal tandem axle weight limit on the Interstate is 34,000 pounds.

- AASHTO definitions. These weight limits may vary from State-to-State depending on local laws and limits in effect before the Federal limits were established in 1956.
A distinction is made at the 8-foot distance in Table B (page 5) due to the tandem axle weight definition causing a considerable difference in the axle load, depending on whether the spacing of the axles is 8 feet and less or more than 8 feet. The axle weight limit for any spacing greater than 8 feet $(96$ inches) shall be in accordance with the bridge formula. The tandem axle weight definition is not applicable when the axle spacing exceeds 96 inches. For example, three axles with an extreme spacing of 97 inches (more than 8 feet) can carry a load of 42,000 pounds as shown in Figure 3.

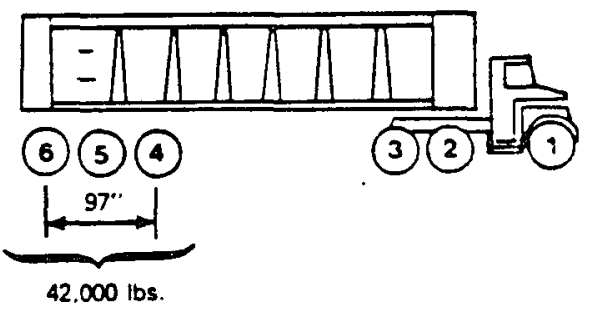

Figure 3

The Federal law states that any consecurive two or more axles may not exceed the weight as computed by the formula even though the single axles, tandem . axles, and gross weights are within legal requirements.

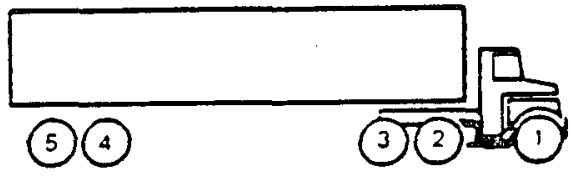

Figure 4

The most common vehicle (axle arrangement) checked for weight limit requirements is shown in Figure 4. While the Bridge Formula law applies to each combination of two or more axles, experience shows that axle combinations numbers 1 through 3 , numbers 1 through 5 , and numbers 2 through 5 are the critical combinations that must be checked. If these are found satisfactory, others will be satisfactory. 
The vehicle with weights and axle dimensions as shown in Figure 5 will be used to illustrate a Bridge Formula check.

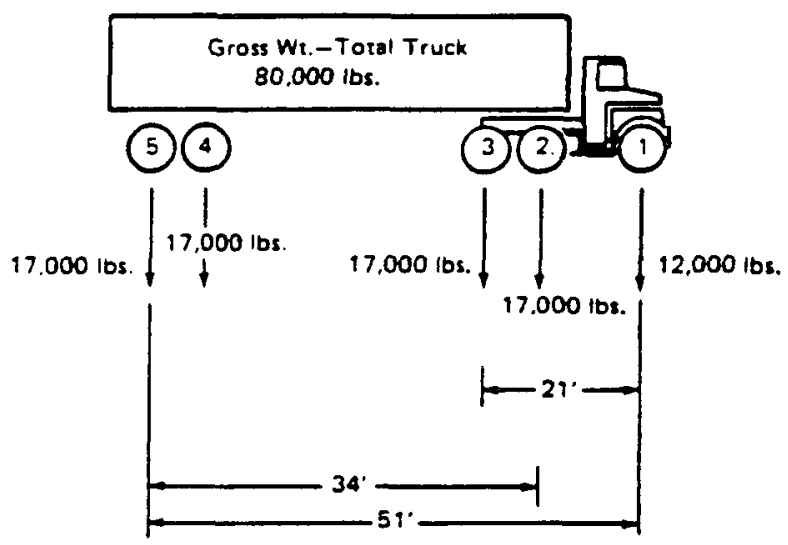

Figure 5

Before checking the axle 1 through 3 combination, a check should be made to see that single, tandem and gross weights are satisfied. The single axle Number 1 does not exceed 20,000 pounds, tandems 2-3 and 4-5 do not exceed 34,000 pounds, and the gross weight does not exceed 80,000 pounds. Thus, these requirements are satisfied so the first Bridge Formula combination is checked as follows:

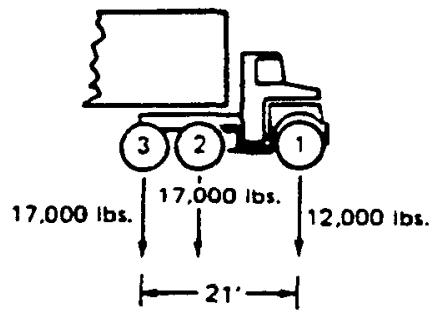

Figure 6

\section{Check of 1 thro 3}

$W$ (actual weight) $=12,000+17,000+17,000=46,000$ pounds (Figure 6).

$N=3$ axies.

$L=21$ feet.

FED - 6

2nd Revised $7 / 1 / 84$ $w$ maximum $=500\left(\frac{L N}{N-1}+12 N+36\right)$

$$
=500\left[\frac{(21 \times 3)}{(3-1)}+(12 \times 3)+36\right]=51,500 \# .
$$

$W$ maximum $=51,500$ which is more than the actual weight of $46,000 \mathrm{H}$ so the Bridge Formula requirement is satisfied.

\section{Example-Bridge Table B}

This same number $(51,500$ ) could have been obrained from Bridge Table $B$ as shown by reading down the left side to $L=21$ and across to the right where $\mathrm{N}=3$.

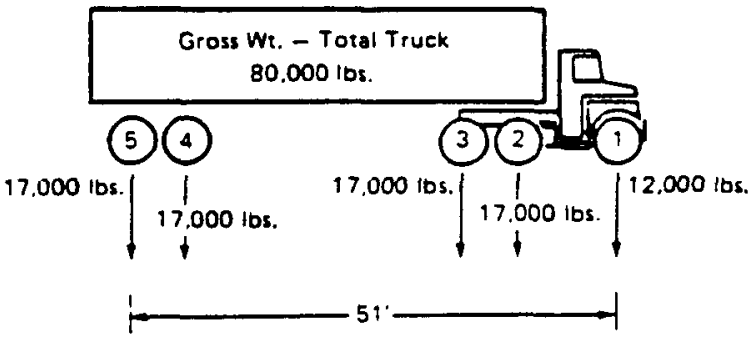

Figure 7

\section{Now check axles 1 thru 5}

$W$ (actual) $=12,000+17,000+17,000+17,000+$ $17,000=80,000 *$ (Figure 7).

$W$ maximum, from Table $B$ for $L$ of 51 feet and $N$ of $S=80,000 \mathrm{H}$.

Therefore, this axle spacing is satisfactory. 


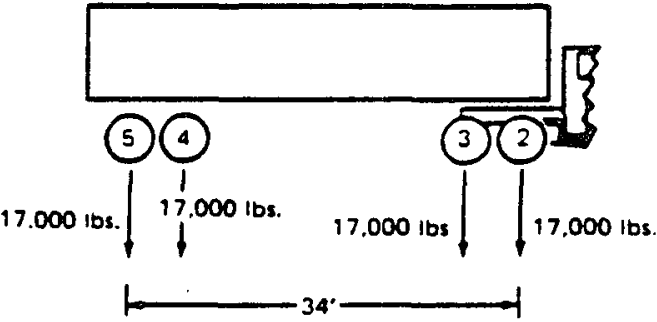

Figure 8

Now check axles 2 thru 5

$W($ actual $)=17,000+17,000+17,000+17,000=$ 68,000" (Figure 8).

W maximum, from Table $B$ for " $L$ " of 34 feet and "N" of $4=64,500 \%$.

This is a "TILT" or violation in that the actual weight exceeds the maximum allowed weight for the given axle spacing. To correct the situation, some load must be removed from the truck or the axle spacing (34-foot dimension) increased.

\section{Exception to Formula and Table B}

There is one exception to use of the formula or Table B-two consecutive sets of tandem axles may carry a gross load of 34,000 pounds each providing the overall distance between the first and last axles of such consecutive sets of tandem axles is 36 feet or more. For example, a 5 axle truck tractor semi-trailer may be used to haul a full 34,000 pounds on the tandem of the tractor (axles 2 and 3 ) and the tandem of the trailer (axles 4 and 5) provided there is a spacing of 36 feet or more between axles 2 and 5 . A spacing of 36 feet or more for axles 2 through $S$ is satisfactory for an actual $W$ of 68,000 pounds even though the formula or Table $B$ computes $W$ maximum to be 66,000 to 67,500 pounds for spacings of 36 to 38 feet. This special exception is stated in the Federal law.
Bridge Formala Application to Single Unt Trucks

The same procedure described above can be used to check any axle combinations but as a general rule several axjes spaced closely together will usually give the most critical situation.
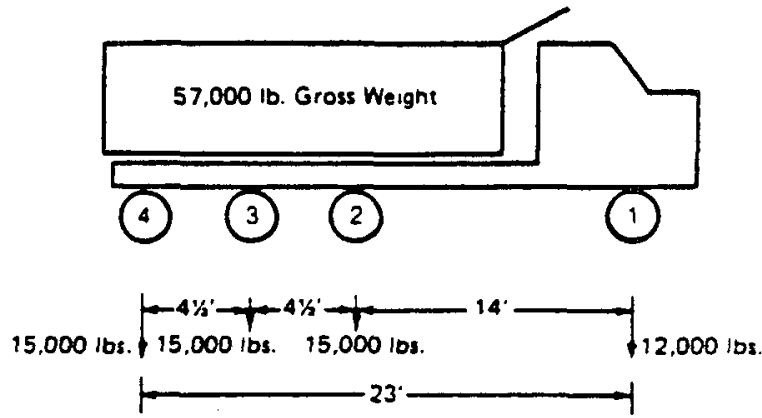

Figure 9

The truck in Figure 9 satisfies single axle restrictions $(12,000 \mathrm{~W}$ is less than $20,000 \mathrm{~m})$, tandem axle restrictions $(30,000 \mathrm{H}$ is less than $34,000 \mathrm{~m})$ and gross limits $(57,000 \mathrm{~m}$ is less than $80,000 \mathrm{~m})$. With these restrictions satisfied a check will be made for Bridge Formula requirements, axies 1 through 4 .

$W($ actual $)=12,000+15,000+15,000+15,000=$ $57,000 \%$.

$W$ maximum for " $N$ " of 4 and " $L$ " of 2.3 feet = s7,500 from Table " $B$ ".

Since axies 1 thru 4 are satisfactory, check axles 2 thru 4:

$W($ actual $)=15,000+15,000+15,000=45,000 \#$.

$W$ maximum for " $N$ " of 3 and " $L$ " of 9 feet $=42,500$ (From Table B).

This a $T I L T$ or a violation. The load would have to be reduced, axles added, or spacing changed to meet requirements.

\section{CAUTION}

This pamphlet has attempted to explain the purpose of the bridge formula and Federal requirements applicable to the Interstate System, but procedures to determine the related weight limits and axte spacing requirements for specific vehicles may vary from State to State. 
APPENDIX C

REPRESENTATIVE CASK/VEHICLE CONFIGURATIONS 
Department of Energy - Office of Civilian Radioactive Waste Management

\section{TON SPENT FUEL CASK}

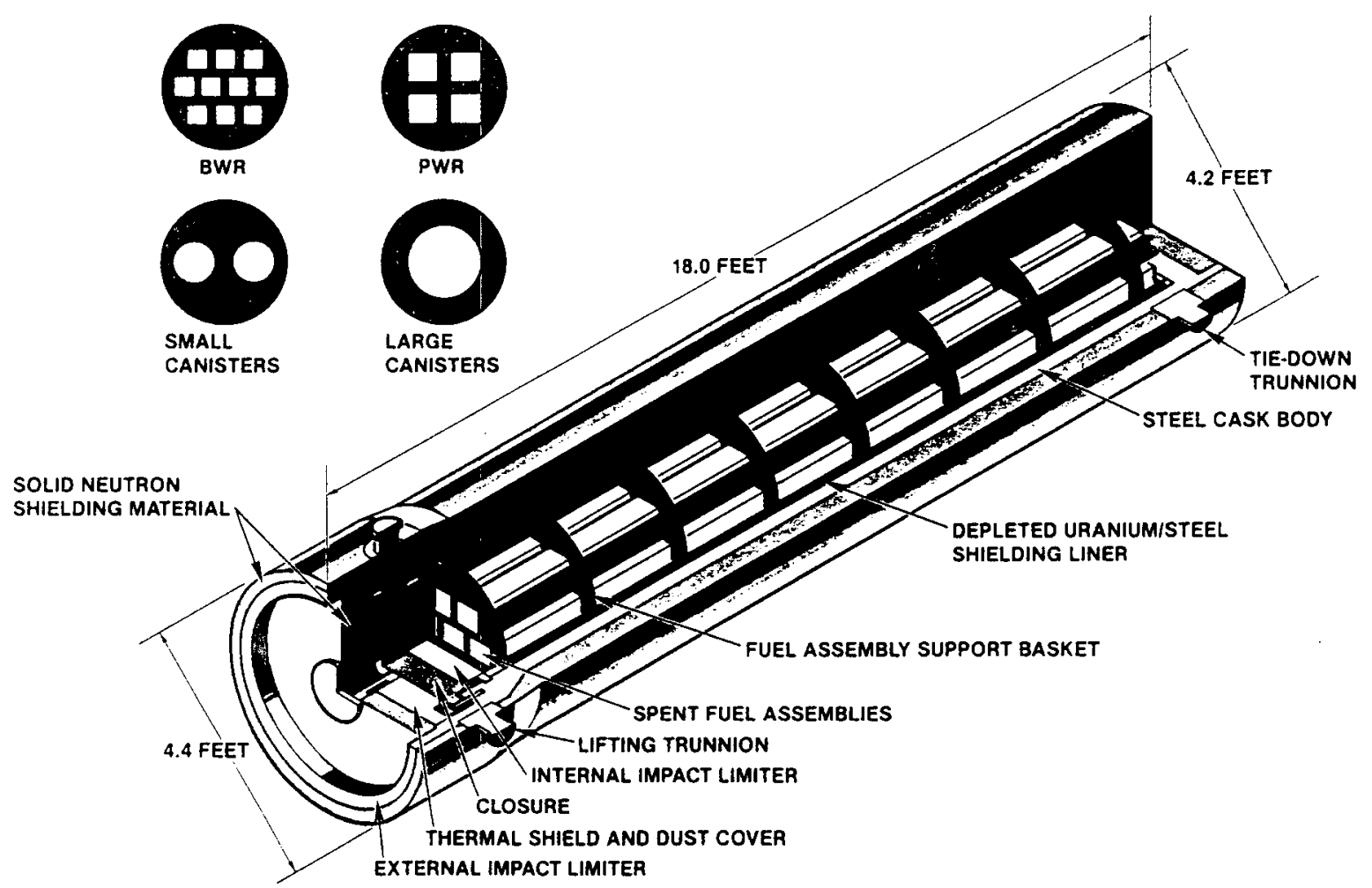

This brochure describes a 40 ton spent fuel cask concept which could be used for intermodal transport where handling constraints at a shipping facility prevent use of heavier rail casks. This cask concept contains features expected to be present on casks provided by private industry although there may be some design differences. The data presented here are representative but not exact.

This cask is a design for transporting four PWR or ten BWR spent fuel assemblies which are at least ten years out of reactor. While spent fuel that has been cooled only five years may be transported to Federal storage and disposal locations, most early shipments will consist of longer cooled fuel. Consequently, this concept shows the larger payload (spent fuel capacity) that is possible with ten year old or longer cooled fuel. In addition, various numbers of consolidated rod waste forms can be accommodated while remaining within an $80,000 \mathrm{lb}$. target weight limit for the cask and its contents. This cask concept is simple in design, capable of site handling operations in either a manual or remote mode.

The concept shown here consists of an outer body of steel with an inner gamma shielding liner of depleted uranium/stainless steel sandwich construction. The cask body shown has a four inch thick wall to provide structural strength. Neutron shielding is provided by four inches of solid elastomer or resin material attached to the outside of the cask wall and clad with a thin shell of steel. The cask is designed for passive cooling with a smooth outer surface and a dry, gaseous cavity atmosphere during transport.

The cask cavity is sealed by a bolted closure head with two O-rings to provide the required degree of tightness. The seais are protected against high temperature from fire by a thermal barrier mounted to the top of the closure head.

This concept has external impact limiters mounted on the cask. A crushable honeycomb internal impact limiter is mounted between the waste forms and the underside of the closure head to reduce peak loads on the head and closure bolts. Different concepts may be employed to absorb energy in the cask during hypothetical accident impacts. The waste forms are supported in the cask cavity by a lightweight structural basket with features to maintain criticality control and to aid in heat rejection.

This cask concept is designed to be versatile in operation with the ability to transport different spent fuel waste forms by changing the support basket. This cask could operate in the overweight truck mode for short distances in combination with rail/barge shipment. The total weight of the cask and its contents will allow the loading of two casks on a rail car while remaining within the limits of the unrestricted rail mode of transport. 
40 TON SPENT FUEL CASK CONCEPT

Overall Size:

Weight:

Cavity Size:

Shielding:

Type Of Containment:

Seals:

Cavity Atmosphere:

Expected Thermal Output (Max.):

Outer Surface Configuration:

Trunnions:

Lifting (Top)

Tie-Down (Bottom)

Waste Forms:

Diameter (in.)

Side Of Square (in.)

Length (in.)

Equiv. Number Of SFAs(1)

Weight (lb.)

Min. Age (yr.) (2)

Cask Capacity:

Number Of Waste Forms $(3)$

Equiv. SFAs (4)

Total Cargo Weight (lb.)(5)

Cask Weight:

Empty (lb.)(6)

Full (lb.)
Outside Diameter (Top)

Outside Diameter (Bottom)

Overall Length

Cask Weight-Empty (Max.)

Cask Weight-Full (Max.)

Inside Diameter

Inside Length

Gamma Type:

Equivalent Steel Thickness:

Cask Side

Cask Top

Cask Bottom

Neutron Type:

Thickness:
52 in.

50 in.

216 in.

$67,500 \mathrm{lb}$.

$80,000 \mathrm{lb}$.

$30.0 \mathrm{in.}$

$176.5 \mathrm{in.}$

Depleted Uranium/Steel

$9.5 \mathrm{in.}$

10.5 in.

10.0 in.

Solid, Organic Material

$4.0 \mathrm{in}$.

Bolted Closure

Double O-Ring

Dry Gas

5.5 Kilowatts

Smooth

$4 @ 90^{\circ}$

$2 @ 180^{\circ}$

Notes: (1) The waste form contains the rods from this number of spent fuel assemblies.

(2) See comment in text.

(3) Cask diameter is optimized for intact fuel assemblies. This cask may be weight, not quantity, limited for other waste forms.

(4) The cask can carry the rods from this number of spent fuel assemblies.

(5) Rounded to nearest $500 \mathrm{lb}$.

(6) Includes fuel assembly or canister support baskets which vary in weight with the waste form.

Intact

Spent Fue

Assemblies

PWR BWR

$\overline{8.4} \quad 5.5$

$160 \quad 176$

1

$1450 \quad 700$

10
Square Canisters
Of Consolidated Rods (2:1 Consolidation) PWR BWR

$\begin{array}{cc}- & - \\ 8.4 & 5.5 \\ 152 & 161 \\ 2 & 2 \\ 2900 & 1400 \\ 10 & 10\end{array}$

Small Diameter

Canisters for

Consolidated

PWR BWR

$12.8 \quad 12.8$

$-$

158

3

5100

10

2
6

10,000

2
14

10,000

67,000

77,000
Large Diameter

Canisters for

Consolidated

$\frac{\text { Rods }}{\text { PWR BWR }}$

$16.9 \quad 18.9$

- -

$160 \cdot 169$

$6 \quad 17$

$10,700 \quad 13,400$

1010

$\begin{array}{cccccccc}4 & 10 & 4 & 8 & 2 & 2 & 1 & 1 \\ 4 & 10 & 8 & 16 & 6 & 14 & 6 & 17 \\ 6000 & 7000 & 11,500 & 11,000 & 10,000 & 10,000 & 10,500 & 13,500 \\ & & & & & & & \\ 67,000 & 67,500 & 67,000 & 67,500 & 67,000 & 67,000 & 66,500 & 66,500 \\ 73,000 & 74,500 & 78,500 & 78,500 & 77,000 & 77,000 & 77,000 & 80,000\end{array}$


Department of Energy - Office of Civilian Radioactive Waste Management

\section{TRUCK SPENT FUEL CASK}

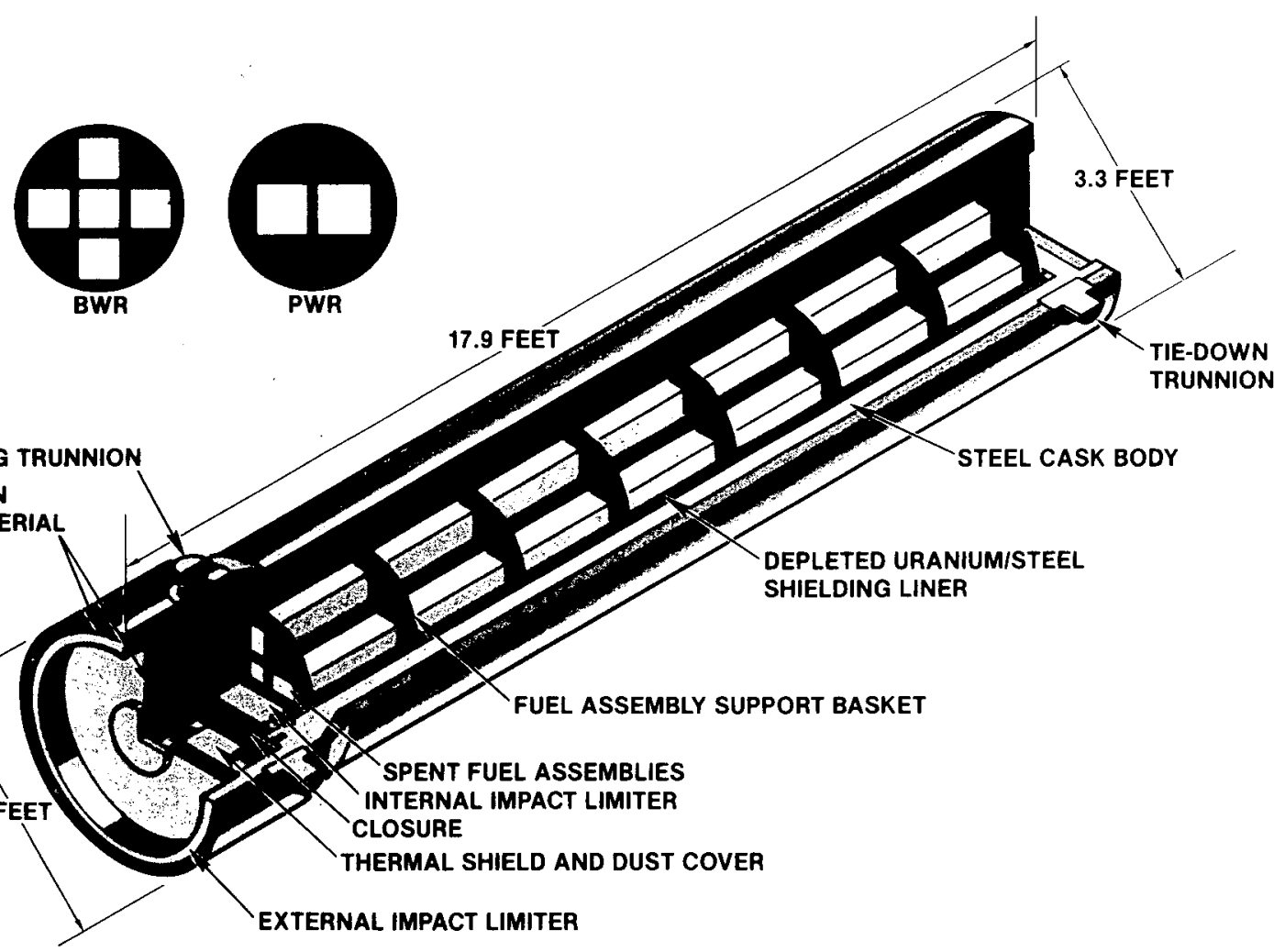

Reusable cask systems that can be transported by legal weight truck will be used to ship spent fuel and high level waste in the United States. This brochure describes a spent fuel cask concept which contains features expected to be present on casks provided by private industry although there may be some design differences. The data shown here are representative but not exact.

This cask is a design for transporting PWR or BWR spent fuel assemblies (SFAs) which are at least ten years out of reactor. While spent fuel that has been cooled only five years may be transported to Federal storage and disposal locations, most early shipments will consist of longer cooled fuel. Consequently, this concept shows the larger payload (spent fuel capacity) that is possible with ten year old or longer cooled fuel. In the legal weight truck mode, this cask can accommodate either two PWR or five BWR SFAs. In addition, sufficient shielding is provided to ship at-reactor consolidated fuel rods in square canisters (two-into-one consolidation) or consolidated rods in circular canisters. The cask is simple in design, capable of site handling operations in either a manual or remote mode.

The concept shown here consists of an outer body of steel with an inner gamma shielding liner of depleted uranium/stainless steel sandwich construction. The cask body shown here is nominally three inches thick to provide the structural strength required. The neutron shielding needed for the spent fuel is provided by a three inch thickness of solid elastomer or resin material clad with a thin shell of steel. The outside of the cask is smooth. The cask is designed for passive cooling with a dry cavity atmosphere during transport.

The cask cavity is sealed by a bolted closure head with two O-rings to provide the degree of tightness needed. These seals are protected against high temperature from fire by a thermal barrier mounted to the top of the closure head.

This concept has external impact limiters mounted on the cask. An internal impact limiter made of crushable honeycomb material is mounted between the waste forms and the underside of the closure head to reduce peak loads on the head and closure bolts. Different concepts may be employed to absorb energy in the cask during hypothetical accident impacts. The waste forms are supported in the cask cavity by a lightweight structural basket with features to maintain criticality control and to aid in heat rejection.

This cask concept is designed to be versatile in operation with the ability to transport different spent fuel waste forms by changing the support basket. The weight of some of these loads will require lightweight tractors/semi-trailers to qualify for an unrestricted truck transport mode. 
TRUCK SPENT FUEL CASK CONCEPT

Overall Size:

Weight:

Cavity Size:

Shielding:

Type Of Containment:

Seals:

Cavity Atmosphere:

Expected Thermal Output (Max.):

Outer Surface Configuration:

Trunnions:

Lifting (Top)

Tie-Down (Bottom)

Waste Forms:

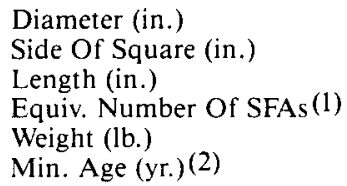

Cask Capacity:

Number Of Waste Forms (3)

Equiv. SFAs (4)

Total Cargo Weight (lb.) (5)

Cask Weight:

$$
\text { Empty (lb.) }{ }^{(6)}
$$

Full (lb.)

Allowable Vehicle Weight:

Without Cask (lb.)

Loaded (lb.)

$\%$ Of Allowable Weight:
Outside Diameter (Top)

Outside Diameter (Bottom)

Overall Length

Cask Weight-Empty (Max.)

Inside Diameter (with shielding liner)

Inside Length (with shielding liner)
Gamma Type:
Cask Side
Cask Top
Cask Bottom
Neutron Type:

Equivalent Steel Thickness:

Thickness:
44 in

39 in.

$215 \mathrm{in}$.

$48,000 \mathrm{lb}$.

22.7 in.

$176.5 \mathrm{in}$.

Depleted Uranium/Steel

9.3 in

10.0 in.

9.5 in.

Solid, Organic Material

$$
3.0 \text { in. }
$$

Bolted Closure

Double O-Ring

Dry Gas

2.8 Kilowatts

Smooth

$4 @ 90^{\circ}$

$2 @ 180^{\circ}$

Notes: (1) The waste form contains the rods from this number of spent fuel assemblies.

Square Canisters

Intact

Spent Fuel Assemblies (SFAs) PWR BWR

-

$\overline{8.4}$

160

1

1450

10

$$
\begin{aligned}
& 2 \\
& 2
\end{aligned}
$$

3000

47,500

50,500

5.5

176

1

700

10

5
5

3500

29,500

80,000

$100 \%$

Of Consolidated Rods (2:1 Consolidation) PWR BWR

\section{4}

8.4
152

2

2900
10

$\begin{array}{ll}2 & 4 \\ 4 & 8\end{array}$

6000

5500

48,000

51,500

47,500

53,500

48,000

53,500

\section{8,500}

80,000

26,500

80,000

26,500

\begin{tabular}{|c|c|}
\hline \multicolumn{2}{|c|}{$\begin{array}{l}\text { Small Diameter } \\
\text { Canisters for } \\
\text { Consolidated Rods }\end{array}$} \\
\hline PWR & BWR \\
\hline 12.8 & 12.8 \\
\hline 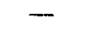 & - \\
\hline 158 & 164 \\
\hline 3 & 7 \\
\hline 5100 & 4900 \\
\hline 10 & 10 \\
\hline 1 & 1 \\
\hline 3 & 7 \\
\hline 5000 & 5000 \\
\hline 47,500 & 47,500 \\
\hline 52,500 & 52,500 \\
\hline 27,500 & 27,500 \\
\hline 80,000 & 80,000 \\
\hline $100 \%$ & $100 \%$ \\
\hline
\end{tabular}

80,000

$100 \%$

(2) See comment in text.

(3) Cask diameter is optimized for intact fuel assemblies. This cask may be weight, not quantity, limited for other waste forms.

(4) The cask can carry the rods from this number of spent fuel assemblies.

(5) Rounded to nearest $500 \mathrm{lb}$.

(6) Includes fuel assembly or canister support baskets which vary in weight with the waste form. 


\section{REPRESENTATIVE TRAILER AND AXLE CONFIGURATION}

FOR 40 TON CASK PER TSMT

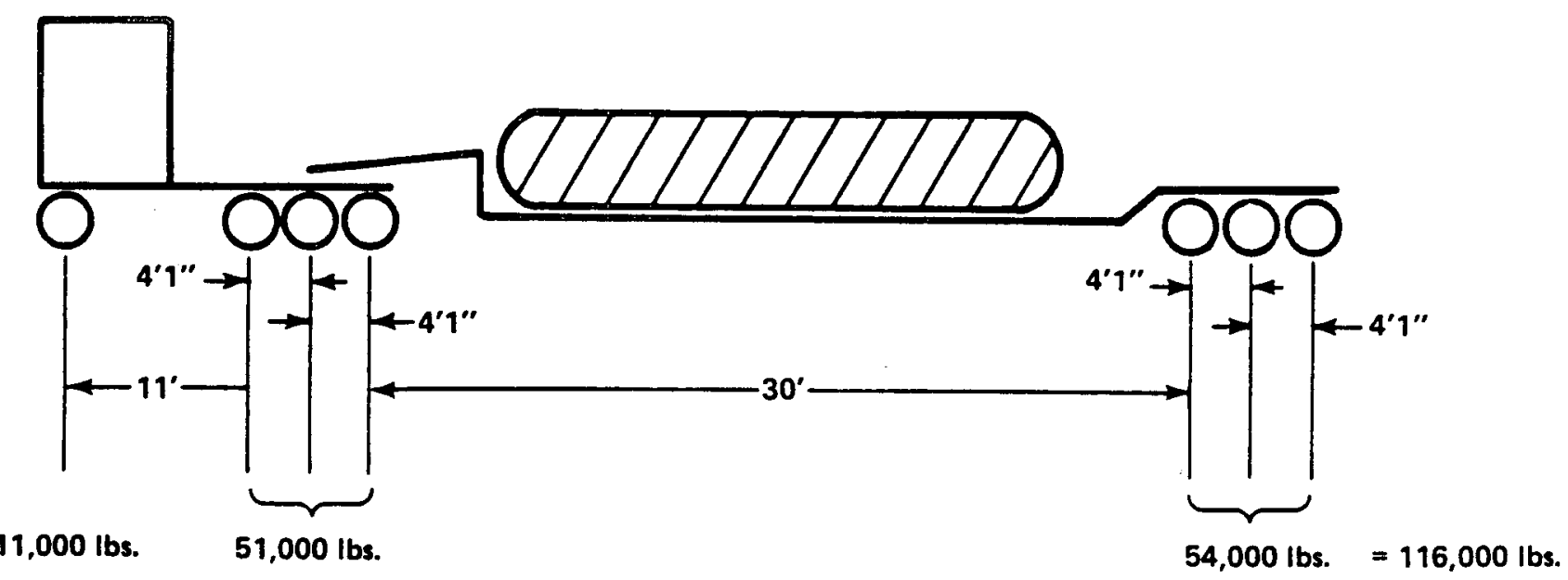


APPENDIX D

CALCULATION OF EQUIVALENT STANDARD AXLE LOADS (ESALS) 


\section{APPENDIX D}

\section{CALCULATION OF EQUIVALENT STANDARD AXLE LOADS (ESALS)}

\section{DERIVATION OF EQUIVALENT \\ STANDARD AXLE LOADS}

In evaluating the highway damage caused by trucks with different weights and axle configurations, the first step is to convert the axle loadings into a standard unit of measure called Equivalent Standard Axle Loads (ESALS). A method for computing ESALs, based on the widely used and accepted American Association of State Highway and Transportation Officials (AASHTO) pavement design equations, is presented below.

The standard AASHTO equations and tables were developed by applying nonlinear regression analyses of data collected in the series of AASHTO road tests using single- and tandem-axle vehicles during the late 1950s. These equations and tables have been modified and updated since they were first published in 1962, based on later research conducted under the National Cooperative Highway Research Project. The latest published version of the AASHTO standard equations and tables is in the 1981 revised edition of the Interim Guide for Design of Pavement Structures.

The Interim Guide contained equations for single axles and tandem axles only. Tridem and higher axle configurations were treated as tandem axles for pavement design purposes. However, in response to the increasing use of tridem axles today, AASHTO has recently issued separate tables for triple axle configurations in the Proposed AASHTO Guide for Design of Pavement Structures, July, 1985 (NCHRP 20-7/24) (AASHTO, 1985). The Proposed Guide was approved by the AASHTO Executive Committee in October, 1985 and will be published in final form in the spring of 1986. Because the new tridem axle tables are based on simple extrapolations of equations developed from singleand tandem-axle data, there was some concern about their validity. AASHTO compared their tridem axle tables with other mechanistic studies and found the results to be reasonably close, justifying their approach.

The AASHTO Road Test data resulted in separate equations for flexible (asphalt) and rigid (cement) pavements which are presented below. 
The equations for flexible pavements are:

$$
\begin{gathered}
\log W_{x}=5.93+9.36 \log (S N+1)-4.79 \log \left(L_{x}+L_{2}\right)+4.33 \log \left(L_{2}\right)+{ }^{G} /_{B_{x}}{ }_{(F-1)} \\
G_{t}=\log \left[\frac{4.2-P_{t}}{4.2-1.5}\right] \\
{ }_{B}=0.40+\frac{0.081\left(L_{x}+L_{2}\right)^{3.23}}{(S N+1)^{5.19} L_{2}^{3.23}}
\end{gathered}
$$

The equations for rigid pavements are:

$$
\begin{gathered}
\log W_{x}=5.85+7.35 \log (D+1)-4.62 \log \left(L_{x}+L_{2}\right)+3.28\left(L_{2}\right)+G_{t} / B_{x} \\
G_{t}=\log \left[\frac{4.5-P_{t}}{4.2-1.5}\right] \\
{ }_{B x}=1.0+\frac{3.63\left(L_{1}+L_{2}\right)^{5.2}}{(D+1)^{8.46} L_{2}^{3.52}}
\end{gathered}
$$

$W_{x}$ is the number of axle load applications of weight $L_{x}$ (in 1,000 pounds) and axle type $L_{2}$ ( 1 for single, 2 for tandem, and under the recent revision, 3 for tridem axles) that would reduce the serviceability index of a pavement to the level $\left(P_{t}\right)$ at which resurfacing becomes necessary at time t. $S N$ and $D$ are measures of total pavement strength for flexible and rigid pavements, respectively. $S N$ is a structural number based on the strengths of the various layers of a flexible pavement. $D$ is the slab thickness, in inches, of a rigid pavement. 
These equations are used to convert all axle loads to a standard unit of measure, i.e., 18,000-pound (18-kip) single axles. The conversion procedure is illustrated below using the AASHTO recommended values of $S N=3$, $\mathrm{D}=9$ inches, and $\mathrm{P}_{\mathrm{t}}=2.5$ for major highways (such as the Interstate Highways). These values have been widely adopted and are used in the present study.

\section{Flexible Pavements}

For an 18-kip $\left(L_{x}=18\right)$ single-axle $\left(L_{2}=1\right)$ load, equations $(F-1)$ to $(F-3)$ may be written as:

$$
\begin{gathered}
\log W_{18}=5.93+9.36 \log (4)-4.79 \log (19)+G_{t} /_{\beta_{18}} \\
G_{t}=\log \left[\frac{4.2-2.5}{4.2-1.5}\right]=-0.20091484 \\
{ }_{18}=0.40+\frac{0.081(19)^{3.23}}{4^{5.19}}=1.22066856
\end{gathered}
$$

For any other axle loading $\left(L_{x}\right)$, the corresponding equations are:

$\log \left(W_{x}\right)=5.93+9.36 \log (4)-4.79 \log \left(L_{x}+L_{2}\right)+4.33 \log \left(L_{2}\right)+G_{t} / B_{x}$

$$
G_{t}=-0.20091484
$$

$$
B_{x}=0.40+\frac{0.081\left(L_{x}+L_{2}\right)^{3.23}}{4^{5.19} L_{2}^{3.23}}
$$


Subtracting equation $(F-1 B)$ from $(F-1 A)$, gives the basic formula for flexible pavements:

$$
\log \left(\frac{W_{18}}{W_{x}}\right)=4.79 \log \left(L_{x}+L_{2}\right)-4.79 \log (19)-4.33 \log \left(L_{2}\right)-G_{t} /_{\beta_{x}}+G_{t} / \beta_{18}
$$

\section{Rigid Pavements}

Applying the same procedure to equations (R-1) to (R-3), gives, for 18-kip single axles:

$$
\begin{gathered}
\log W_{18}=5.85+7.35 \log (9+1)-4.62 \log (19)+{ }^{G_{t}} /_{B_{18}} \\
G_{t}=\log [0.333(4.5-2.5)]=-0.1765258 \\
{ }_{B} 18=1.0+\frac{3.63(19)^{5.20}}{10^{8.46}}
\end{gathered}
$$

and for any other axle loading $L_{x}$ :

$$
\log W_{x}=5.85+7.35 \log (9+1)-4.62 \log \left(L_{x}+L_{2}\right)+3.82 \log \left(L_{2}\right)+G_{t} / B_{x}
$$

$$
G_{t}=-0.1765258
$$




$$
B_{x}=1.0+\frac{3.63\left(L_{x}+L_{2}\right)^{5.20}}{10^{8.46} L_{2}^{3.52}}
$$

Subtracting (R-1B) from $(R-1 A)$, we get the basic formula for rigid pavements:

$$
\log \left(\frac{W_{18}}{W_{X}}\right)=4.62 \log \left(L_{x}+L_{2}\right)-4.62 \log (19)-t_{B_{X}}+{ }^{G} /_{B_{18}}
$$

Equivalent Standard Axle Loads (ESALs), defined as the ratio $W_{18} / W_{X}$, can now be readily computed for flexible and rigid pavements from equations $(F-4)$ and $(R-4)$, respectively.

This procedure yields a measure of the highway damage caused by any axle load in terms of a standard unit of measure. However, a truck typically has multiple axles of varying axle loads. Thus, to compute the relative highway damage of a given truck in comparison to the standard 18-kip single-axle load, the ESALs for each axle on the truck need to be summed.

\section{CALCULATION OF REPRESENTATIVE CASK/VEHICLE ESALS}

Using the above procedures, ESALs can be calculated for each cask/ vehicle configuration analyzed in Chapter 4, namely:

LWT 1 : One 10-kip single axle, one 32.5-kip tandem axle and one 32-kip tandem axle

LWT2: One 11-kip single axle, two 34-kip tandem axles

OWT 1 : One 12-kip single axle, one 47-kip tridem axle, and one 52-kip tridem axle

$\mathrm{OWT}_{2}$ : One 11-kip single axle, one 51-kip tridem axle, and one 54-kip tridem axle. 


\section{A. Flexible Pavements}

Using equation (F-4), the following ESAL values are calculated for each axle weight.

Single-Axle ESALS

10-kip: $W_{18} / w_{10}=0.1175$

11-kip: $W_{18} / W_{11}=0.1668$

12-kip: $\quad W_{18} / w_{12}=0.2288$

Tandem-Axle ESALs

32-kip: $\quad W_{18} / W_{32}=0.8892$

32.5-kip: $W_{18} / W_{32.5}=0.9411$

34-kip: $W_{18} / W_{34}=1.1114$

Tridem-Axle ESALs

47-kip: $W_{18} / W_{47}=0.9922$

51-kip: $\quad W_{18} / W_{51}=1.3393$

52-kip: $\quad W_{18} / W_{52}=1.4394$

54-kip: $\quad W_{18} / W_{54}=1.6576$

The next step is simply to add ESAL values for the axle weight associated with each configuration as follows:

$$
\begin{aligned}
\mathrm{LWT}_{1} & =\mathrm{ESAL}_{10}+\mathrm{ESAL}_{32.5}+\mathrm{ESAL}_{32} \\
& =0.1175+0.9411+0.8892 \\
& =1.95 \\
\mathrm{LWT}_{2} & =\mathrm{ESAL}_{11}+2\left(\mathrm{ESAL}_{34}\right) \\
& =0.1668+2(1.1114) \\
& =2.38 \\
\mathrm{OWT}_{1} & =\mathrm{ESAL}_{12}+\mathrm{ESAL}_{47}+\mathrm{ESAL}_{52} \\
& =0.2288+0.9922+1.4394 \\
& =2.66 \\
\mathrm{OWT}_{2} & =\mathrm{ESAL}_{11}+\mathrm{ESAL}_{51}+\mathrm{ESAL}_{54} \\
& =0.1668+1.3393+1.6576 \\
& =3.17
\end{aligned}
$$


B. Rigid Pavements

Using equation (R-4), the following ESAL values are calculated for each axle weight.

Single-Axle ESALS

10-kip: $W_{18} / W_{10}=0.817$

11-kip: $\quad W_{18} / W_{11}=0.1220$

12-kip: $W_{18} / W_{12}=0.1764$

Tandem-Axle ESALS

32-kip: $W_{18} / W_{32}=1.4908$

32.5-kip: $W_{18} / W_{32.5}=1.5906$

34-kip: $\quad W_{18} / W_{34}=1.9194$

Tridem-Axle ESALS

47-kip: $W_{18} / W_{47}=2.2851$

51-kip: $\quad W_{18} / W_{51}=3.1834$

52-kip: $\quad W_{18} / W_{52}=3.4420$

54-kip: $\quad W_{18} / W_{54}=4.0033$

The next step is to add ESAL values for the axle weights associated with each truck configuration as follows:

$$
\begin{aligned}
\mathrm{LWT}_{1} & =\mathrm{ESAL}_{10}+\mathrm{ESAL}_{32.5}+\mathrm{ESAL}_{32} \\
& =0.0817+1.5906+1.4908 \\
& =3.16 \\
\mathrm{LWT}_{2} & =\mathrm{ESAL}_{11}+2\left(\mathrm{ESAL}_{34}\right) \\
& =0.1220+2(1.9194) \\
& =3.96 \\
\mathrm{OWT}_{1} & =\mathrm{ESAL}_{12}+\mathrm{ESAL}_{47}+\mathrm{ESAL}_{52} \\
& =0.1764+2.2851+3.4420 \\
& =5.90 \\
\mathrm{OWT}_{2} & =\mathrm{ESAL}_{11}+\mathrm{ESAL}_{51}+\mathrm{ESAL}_{54} \\
& =0.1220+3.1834+4.0033 \\
& =7.31
\end{aligned}
$$




\section{Composite ESAL Values}

The Interstate Highway system is composed of approximately 43 percent flexible pavements (asphalt) and 57 percent rigid pavement (concrete). Relative highway damage among vehicles of different configurations will vary from rigid to flexible pavements. Since exact routes from reactors to repository are not known, it is assumed here that, on the average, repositoryrelated truck transport will be conducted over highway types reflective of the nation as a whole. Consequently, the ESAL values are adjusted by the 43:57 ratio to reflect relative repository-related highway damage.

$$
\begin{aligned}
L W T_{1} & =0.43(1.95)+0.57 \text { (3.16) } \\
& =2.64 \\
L W T_{2} & =0.43(2.39)+0.57(3.96) \\
& =3.28 \\
\mathrm{OWT}_{1} & =0.43(2.66)+0.57(5.90) \\
& =4.51 \\
\mathrm{OWT}_{2} & =0.43(3.17)+0.57(7.31) \\
& =5.53
\end{aligned}
$$

These composite ESAL values are used to compare relative highway damage for the repository program and are shown in Table 14 of the text. 
APPENDIX E

SUMMARY OF DOE TRAFFIC MANAGER RESPONSES TO QUESTIONNAIRE ON OVERWEIGHT NUCLEAR SHIPMENTS 
APPENDIX E

SUMMARY OF DOE TRAFFIC MANAGER RESPONSES TO QUESTIONNAIRE

ON OVERWEIGHT NUCLEAR SHIPMENTS

1. To what extent do you, as the DOE shipper, become involved with the State overweight permit process?

Response: DOE and contractor traffic managers (TMs) have very little to do with the overweight permit process except for carrier oversight. The carrier is responsible for obtaining all permits unless it is a government vehicle or trailer. Then, DOE must get involved and obtain permits, but this is unusual.

2. What are the major advantages in moving nuclear waste via overweight trucks? What are the disadvantages?

Response: DOE TMs identified relatively few advantages for OWT shipments compared to disadvantages. The primary advantages included increased capacity and fewer shipments relating to OWT. Sixteen separate disadvantages were identified. The major areas and number of times mentioned are as follows:

$\begin{array}{ll}\text { Permit procedures/approvals } & 5 \\ \text { Restricted hours of travel } & 4 \\ \text { Permit fees } & 3 \\ \text { Need for specialized equipment } & 3 \\ \text { Loss of control (threat of permit denial) } & 3 \\ \text { Greater cost for OWT } & 3\end{array}$

3. How does the fact that nuclear waste is involved affect the difficulties of obtaining a State OWT permit?

Response: Nine of the 11 TMs which completed questionnaires believe that the fact that nuclear waste is involved will greatly influence an overweight permit approval or conditions related to an approval. Only one TM believed that the nature of the cargo had little effect.

4. Which States are the most difficult to deal with on overweight truck shipments?

Response: Most of the TMs expressed their opinion that most States are becoming more stringent in their OWT permit programs. Twenty-five different States were specifically identified by one or more TMs as being particularly difficult to deal with. The States most of ten mentioned were California, Missouri, Illinois, and Michigan. 
5. Are there a sufficient number of carriers with the capacity and willingness to conduct overweight nuclear shipments on a routine basis?

Response: Virtually a 11 TMs believe that sufficient carriers exist with the expertise to conduct nuclear OWT campaigns.

6. Please identify the primary carriers you have utilized for overweight shipments--both nuclear and non-nuclear.

Response: TMs identified 32 different carriers that have been utilized for nuclear and non-nuclear overweight shipments.

7. What are the actual costs of transporting OWT vs. LWT? A complete cost breakdown of a sample would be helpful.

Response: Ten of the 11 TMs indicated that costs are higher for OWT than for LWT. Four TMs provided a sample case to illustrate the cost differential between OWT and LWT which ranged from 50 percent to 90 percent higher for OWT per shipment. One case analysis involved a shipping campaign in which the effect of fewer OWT shipments was evaluated. Even in this case, the OWT campaign was costed at 90 percent greater than the LWT campaign. One TM stated that OWT costs have run $\$ 2 / \mathrm{mile}$ higher than LWT. It is also apparent from these responses that State permit fees can add substantially to the cost of OWT. The cost factors which are greater for OWT include cask lease charges per trip (due to increase in shipment time caused by permit restrictions), special equipment surcharges, detention charges, circuitous routing, greater mileage, and State permit fees.

8. One possible type of overweight truck shipment would be to move a rail cask for very short distances between reactors with no rail access to the closest railhead. This could involve super-heavyweight moves of as much as 200,000 pounds. From your experience with overweight carrier operations and with State permitting, is this feasible?

Response: A mixed response was received concerning super-heavyweight moves between reactors and railheads. Five TMs believed this type of move was feasible, principally on the basis of the belief that carriers will do anything for the right amount of money. Four TMs do not believe such moves are feasible on a repetitive basis (though occasional single trips may be feasible). Two other TMs did not state a clear opinion.

9. In your opinion, are there new technologies (such as advanced trailer design) that need to be developed to accommodate what would normally be OWT shipments for the commercial repository program?

Response: Traffic managers generally do not believe new technology for trailers or vehicles will be necessary for future OWT campaigns. Most believe that sufficient equipment is now available unless "exceedingly" heavy casks are developed. Two TMs believe that new technology is needed in the areas of vehicle weight distribution (number of axles, tire pressure, size of tires, etc.) and lighter vehicle/trailer components. 
10. If an OWT cask is to be developed, are there peculiar design features that should be considered from a carrier and traffic manager perspective? please identify or give examples if possible.

Response: Four TMs did not bother to answer this question because of their clear opposition to the very idea of developing an OWT cask. The other TMs identified the following design features that should receive careful attention:

Dimensions of cask, especially height

Tie-down capability Loading/unloading capability (no cranes preferably) Transport vehicle "adaptability"

11. What is the most realistic trucking option listed below for moving commercial nuclear waste from reactors without rail access to storage and/or repository sites (check one or identify by letter if "e" is selected)?

a. Legal-weight truck only

b. Overweight truck only

c. Intermodal using OWT cask (i.e., about a 40-ton cask)

d. Intermodal using rail cask (i.e., about a 75-ton cask)

e. Combination of which above

f. None of the above--build rail line to reactor

Response: The extent of DOE traffic management opposition to OWT is illustrated by the response to the options available to this question. Seven TMs identified LWT only as the preferred option. There were four other responses (some TMs selected 2 options) favoring a combination of one option with another. The results are as follows:

Develop LWT only Develop LWT and OWT

Develop LWT, OWT, and intermodal using OWT casks

Develop LWT and intermodal using rail casks

Develop OWT and intermodal using OWT casks

Put in rail line for reactors without rail access 